\title{
Phytotherapy
Research
}

\section{Cactus: chemical, nutraceutical composition and potential bio-pharmacological properties}

\begin{tabular}{|r|l|}
\hline Journal: & Phytotherapy Research \\
\hline Manuscript ID & PTR-20-0783.R2 \\
\hline Wiley - Manuscript type: & Review \\
\hline Date Submitted by the & $10-$ Sep-2020 \\
\hline Complete List of Authors: & $\begin{array}{l}\text { Das, Gitishree ; Dongguk University } \\
\text { Lim, Kyung Jik; Dongguk University } \\
\text { Tantengco, Ourlad Alzeus G. ; University of the Philippines Manila } \\
\text { Carag, Harold M. ; University of the Philippines Diliman } \\
\text { Gonçalves, Sandra; University of Algarve } \\
\text { Romano, Anabela; University of Algarve } \\
\text { Das, Swagat; College of Engineering and Technology, Department of } \\
\text { Biotechnology } \\
\text { Coy-Barrera, Ericsson ; Universidad Militar Nueva Granada } \\
\text { Shin, Han Seung; Dongguk University } \\
\text { Gutiérrez-Grijalva, Erick P. ; Centro de Investigacion en Alimentacion y } \\
\text { Desarrollo AC, Functional Foods and Nutraceuticals } \\
\text { Heredia, JB; Centro de Investigación en Alimentación y Desarrollo AC } \\
\text { PATRA, JAYANTA KUMAR; Dongguk University, }\end{array}$ \\
\hline Keyword: & $\begin{array}{l}\text { Bioactive compounds, cactus, pharmaceutical properties, phytotherapy, } \\
\text { neutraceutical }\end{array}$ \\
\hline
\end{tabular}

\section{SCHOLARONE \\ Manuscripts}




\section{Cactus: chemical, nutraceutical composition and potential bio- pharmacological properties}

Short title: Cactus plants: a comprehensive review

Gitishree Das ${ }^{1}$, Kyung Jik Lim², Ourlad Alzeus G. Tantengco ${ }^{3}$, Harold M. Carag ${ }^{4}$, Sandra

Gonçalves $^{5}$, Anabela Romano ${ }^{5}$, Swagat Kumar Das ${ }^{6}$, Ericsson Coy-Barrera ${ }^{7}$, Han-Seung Shin $^{2}$, Erick Paul Gutiérrez-Grijalva ${ }^{8}$, J. Basilio Heredia ${ }^{9}$, Jayanta Kumar Patra ${ }^{1 *}$

${ }^{1}$ Research Institute of Biotechnology \& medical Converged Science, Dongguk UniversitySeoul, Goyangsi 10326, Republic of Korea.

${ }^{2}$ Department of Food Science \& Biotechnology, Dongguk University-Seoul, Goyangsi 10326, Republic of Korea.

${ }^{3}$ College of Medicine, University of the Philippines Manila, Manila, 1000, Philippines.

${ }^{4}$ Institute of Biology, College of Science, University of the Philippines Diliman, Quezon City, 1104, Philippines.

${ }^{5} \mathrm{MED}$ - Mediterranean Institute for Agriculture, Environment and Development, University of Algarve, Faculty of Sciences and Technology, Campus de Gambelas, Ed. 8, 8005-139 Faro, Portugal.

${ }^{6}$ College of Engineering and Technology, Bhubaneswar, Biju Patnaik University of Technology, Odisha, India.

${ }^{7}$ Bioorganic Chemistry Laboratory, Facultad de Ciencias Básicas y Aplicadas, Universidad Militar Nueva Granada, Campus Nueva Granada, 250247, Cajicá, Colombia.

${ }^{8}$ Cátedras CONACYT-Centro de Investigación en Alimentación y Desarrollo, A.C. Carretera a Eldorado Km. 5.5, Col. Campo El Diez, CP. 80110 Culiacán, Sinaloa, México.

${ }^{9}$ Centro de Investigación en Alimentación y Desarrollo, A.C., Carretera a Eldorado Km. 5.5, Col. Campo El Diez, CP. 80110 Culiacán, Sinaloa, México. 


\section{*Corresponding author}

Dr. Jayanta Kumar Patra

Assistant Professor

Research Institute of Biotechnology, Dongguk University-Seoul, Ilsandong-gu, Goyang, Gyeonggi-do 10326, Republic of Korea

Email.jkpatra.official@gmail.com

\section{Table of contents}

1. Introduction

2. Classification and habitat of cactus plants-

3. Traditional uses of cactus plants

4. Phytochemistry and chemical constituents of Cactus plants

4.1 Alkaloids

4.2 Phenolic

4.3 Natural pigments

4.4 Other compounds

5. Extraction and isolation of bioactive compounds from Cactus plants

6. Pharmacological properties of active constituents from Cactus plants

6.1 Antimicrobial potential

6.2 Antiviral potential

6.3 Antioxidant capacity

6.4 Antidiabetic potential

6.5 Hepatoprotective activity

6.6 Cytotoxic activity

6.7 Anti-inflammatory activity

6.8 Anti-ulcer potential

6.9 Antigenotoxic activity

6.10 Cardioprotective potential

6.11 Neuroprotective potential

7. Clinical trials on Cactus-related substances

8. Conclusions 


\begin{abstract}
Cactus species are plants that grow in the arid and semiarid regions of the world. They have long fascinated the attention of the scientific community due to their unusual biology. Cactus species are used for a variety of purposes, such as food, fodder, ornamental, and as medicinal plants. In the last regard, they have been used in traditional medicine for eras by the ancient people to cure several diseases. Recent scientific investigations suggest that cactus materials may be used as a source of naturally-occurring products, such as mucilage, fiber, pigments, and antioxidants. For this reason, numerous species under this family are becoming endangered and extinct. This review provides an overview of the habitat, classification, phytochemistry, chemical constituents, extraction and isolation of bioactive compounds, nutritional and pharmacological potential with pre-clinical and clinical studies of different Cactus species. Furthermore, conservation strategies for the ornamental and endangered species have also been discussed.
\end{abstract}

Keywords: Bioactive compounds; cactus; pharmaceutical properties; phytotherapy; neutraceutical 


\section{Introduction}

Cactus (plural cacti, cactuses or cactus) is described as a distinct flora that can be found in the arid areas around the world. The Cactaceae family has mainly a tropical distribution, comprises 124 genera and 1438 species distributed in the world (del Socorro Santos-Díaz \& Camarena-Rangel, 2019). In the Columbus voyage to the New World in 1492, Melocactus is among the “"bizarre"-"_species that he presumably collected (Barthlott et al., 2015). In Linnaeus's_Linnaeus's Species Plantarum (1753), he listed around 22 cactus species and tried to differentiate species using morphological characters amidst their "-exotic appearance".." From then on, numerous studies were conducted on the ecology, taxonomy, and biogeography of these plants. There are mMany cactus species that can be found around the world (Figure 1).

Cacti have diverse uses and applications across different cultures around the world. For instance, in America, cacti were used as food, medicine, and cosmetics, even before the time of Christopher Columbus (Lema-Rumińska \& Kulus, 2014; Shetty, Rana, \& Preetham, 2012). Cacti are still used as food in Mexico and Spain, and there is a growing demand for it in the United States and Canada, which by 2016 had a value of 31 and 2.89 million dollars, respectively. Cactus has excellent flavor and nutrition and often eaten as fresh in the form of nutritious vegetables and salad dishes for the young leaves, while its fruits are made as juice (Shetty et al., 2012).

The ethnobotanical use of cacti may vary depending on the country; for instance, in Cuba, they are commonly used as herbal medicines for treating infectious diseases (Andrade, Lucero Mosquera, \& Armijos, 2017; Jiménez-Sierra \& Eguiarte, 2010). They are widely cultivated due to their fruits, which serve as food for the people in Mexico, Colombia, and the United States of America (Arellano \& Casas, 2003). Other cactus species are included in the traditional and cultural practices of different ethnic groups (de Lucena et al., 2013). Moreover, 
they are also utilized as fodder species for goats and other ruminants in the dry season, together with native grasses, to increase milk production and weight of the flock (Duque, 1980).

Some commercial products, such as shampoos and soaps, are mainly produced from cactus species. Food products like biscuits, candies, puddings, and cakes could also be sourced out from cacti (de Lucena et al., 2013). Additionally, some species are also used in constructing house roofs (Pedrosa, 2000). These opportunities provide economic relief to local communities. In India, Shetty et al. (Shetty et al., 2012), reported that cacti are used as a source of livelihood, which provides employment opportunities to the community.

Further reports from ethnobotanical works on cacti species suggest the importance of these species in the daily lives of local cultures. Due to its popularity as medicinal plants in different countries, many experiments have been done to test the biological activities of compounds isolated from cactus species. For example, extracts from Opuntia species contain phenolic compounds, other antioxidants such as ascorbate, pigments such as carotenoids and betalains, and other phytochemicals (Aruwa, Amoo, \& Kudanga, 2018). More research also suggests that phytochemical compounds derived from cacti species have high medical and nutritional importance (El-Mostafa et al., 2014a; Shetty et al., 2012; Ventura-Aguilar, Bosquez-Molina, Bautista-Baños, \& Rivera-Cabrera, 2017).

In this review, we will present a general overview of the traditional and folkloric uses of cactus around the world as food and medicine. This review will also list down studies on the biological activity of isolated compounds from cactus, including the phytochemistry and pharmacological potentials. Moreover, recent pre-clinical and clinical trial information on different cactus species are also discussed.

\section{Classification and habitat of cactus plants}


Cacti are easily recognized because of their distinct morphological features. According to the Angiosperm Phylogeny Group IV (The Angiosperm Phylogeny Group. et al., 2016), cacti belong to the Family Cactaceae under the Order Caryophyllales. A picture depicting the 12 types of growth forms of Family Cactaceae is shown in Figure 2 (Novoa, Le Roux, Robertson, Wilson, \& Richardson, 2015). Previous molecular phylogenetic studies confirm its placement under the Order Caryophyllales (Cuénoud et al., 2002; Schäferhoff, Müller, \& Borsch, 2010; Yang et al., 2015). Cactus species have fleshy stems, and most are succulents and is composed of around 130 genera with 1,600 species. The International Cactaceae Systematics Group (ICSG) further divides the Family Cactaceae into the four subfamilies Cactoideae, Maihuenioideae, Opuntioideae, and Pereskioideae.

The extreme diversity of the Cactaceae family is documented in Mexico (586 species) and southwestern USA, the Central Andes (Peru, Bolivia, southern Ecuador, northeastern Chile, and northwestern Argentina), Brazil, Paraguay, Uruguay ${ }_{2}$ and Argentina (Ortega-Baes et al., 2010). It can also be found in places with a wet season characterized by high temperatures like South Africa and Australia (Ochoa \& Barbera, 2017). Cactus are endemic to America, and their distribution ranges from Canada to Argentina, with the only exception being Rhipsalis baccifera, which was thought to have originated in tropical Americas, followed by dispersal across the Atlantic Ocean by birds to reach southern Africa, Madagascar $_{2}$ and Sri Lanka (Rebman \& Pinkava, 2001). These plants can survive in diverse habitats, including coastal areas, mountains, and deserts. However, they are most abundant and diverse in arid and semiarid regions (Ortega-Baes \& Godínez-Alvarez, 2006).

These species have developed mechanisms and adaptations that allow them to survive in environments with high temperatures. These adaptations include succulence, low stomatal density, thick cuticles, spines, lengthy root systems, and stem tissue alterations to increase the storage of excess water and the Crassulacean acid metabolism (CAM) pathway. This 
photosynthetic pathway allows the uptake of carbon dioxide at night and stomatal closure at daytime, thus, reducing the water loss from transpiration (Cushman, 2001). Hence, their high adaptability in dry or xeric environments. Their seeds can also become dormant to prevent germination during periods of water scarcity (Pérez-Molphe-Balch, Santos-Díaz, RamírezMalagón, \& Ochoa-Alejo, 2015).

Correct taxonomic identification of cactus species remains a big challenge in their use as medicinal plants. This confusion often results in the use of different cactus with the same common name to treat the same disease. For example, common prickly pear can be Opuntia ficus-indica, Opuntia monacantha $a_{2}$ or Opuntia stricta, any of these cactus species can be used for diseases treated with common prickly pear, which may result in lack of efficacy of the cactus used as medicinal plants. Some bioactive compounds may not be present in other species of cactus with the same common or local names of cactus species.

\section{Traditional uses of cactus plants}

More than $80 \%$ of the world population still uses traditional herbal medicines to treat common diseases (Woo, Lau, \& El-Nezami, 2012). Cactus has been widely used as herbal medicines worldwide, especially in developing countries, since ancient times. Numerous ethnobotanical studies have already reported the application of different cactus species in treating different diseases. This traditional knowledge has been passed down from generation to generation orally or through written documents.

Based on published studies, we found 42 species of cactus with ethnobotanical use as herbal medicines (Table 1). Different parts of the cactus (leaf, stem, flower, fruit, exudate, latex) were used in treating different disease conditions. For example, different parts of Opuntia monacantha Haw. can be used to treat different types of diseases. Its latex can be used for constipation; its mucilage can be used to treat piles, pox strains, rheumatism, and 
leprosy; its fruit can be used for gonorrhea and syphilis; and the stem can be used as a cathartic and treatment for dysentery (Arshad et al., 2014; Chetry et al., 2018). The modes of administration can be via an external application (topical applications such as lotions, poultices, eye drops, fumigations, baths, and gargles) or by oral intake as a decoction, infusion $_{2}$ or food.

Most cactus species have poor specificity regarding its medicinal use. One cactus species has different medicinal applications in different countries. For example, Opuntia ficus-indica is used as a medicinal plant in 18 different countries. It has different preparation, mode of administration, and diseases that can be treated in different countries. The fruit of $O$. ficus-indica is used in Italy as a diuretic, and for digestive disorders, while in Mexico it is used to treat wounds; in Morocco to treat stretch marks and wrinkles; in Turkey for joint dislocation, tonsillitis, and anemia; in India as an antispasmodic, diuretic, emollient, astringent, treatment for diarrhea, colitis, irritable bowel syndrome, and benign prostatic hypertrophy; in Peru for liver and kidney inflammation; and in Pakistan as a digestion enhancer -(Ahmet Sargin, 2015; de la Cruz, Malpartida, Santiago, Jullian, \& Bourdy, 2014; Erbay, Anıl, \& Melikoğlu, 2016; Khan \& Ahmad, 2015; Maroyi, 2017; Messaoudi et al., 2015; Pandita, Pandita, \& Pandita, 2013; T. Tuttolomondo et al., 2014; Teresa Tuttolomondo et al., 2014).

There were cactus species that were reported as medicinal plants in only one country. For example, Melocactus bahiensis (Britton \& Rose) Luetzelb., which is mainly distributed in the northern part of eastern Brazil, was only used in Brazil to treat amoeba, catarrh, cough, and whooping cough (de Lucena et al., 2013). Opuntia engelmannii Salm-Dyck ex Engelm is common in south-central and southwestern United States and northern Mexico. Its use as a medicinal plant for diabetes was only reported in Mexico (Estrada-Castillón et al., 2018). 
Aside from medicinal use, cacti also serve as an important source of food in different countries (Shetty et al., 2012). The fruit is the most eaten part of the cactus, but other parts such as the flowers, leaves, roots, and stem can also be consumed food. It can be eaten raw, cooked (roasted, baked, boiled, or mixed with other food), processed as candy or marmalade, preserved in sugar syrup, and made into a drink, juice, or alcoholic beverage.

Additionally, cactus are also popular for agricultural, industrial, and ornamental uses. The sturdy structure of various cactus such as Cereus jamacaru DC. and Echinopsis atacamensis (Phil.) Friedrich \& G.D. Rowley makes them suitable for construction of fence, laths, boards, doors, and window (Aldunate, Villagrán, Armesto, \& Castro, 1983; LimaNascimento, Bento-Silva, Lucena, \& Lucena, 2019; Nunes, Lucena, dos Santos, \& Albuquerque, 2015). Mucilage from different species of cactus such as Opuntia ficus indica and Pereskia aculeata is now being used in the food packaging industry as raw materials for films and coating, and more recently, it and has is now beening developed as a food preservatives (Gheribi \& Khwaldia, 2019). Cactus are also popular ornamental plants in different countries, usually planted in gardens and yards (de Lucena et al., 2013; EstradaCastillón et al., 2018).

Several cactus, such as Cylindropuntia leptocaulis, Opuntia ficus-indica, and Pilosocereus pachycladus, are also used for personal hygiene. Opuntia maxima Mill and Opuntia cochenillifera are used as cosmetics (de Lucena et al., 2013; Estrada-Castillón et al., 2018; Gras et al., 2016; Jost, Ansel, Lecellier, Raharivelomanana, \& Butaud, 2016). Other species such as Trichocereus pachanoi and Lophophora williamsii are used for magic and religious practices in Colombia, while Opuntia dillenii is used in China for exorcising evil spirits (Gao et al., 2019; Gras et al., 2016).

\section{Phytochemistry and chemical constituents of Cactus plants}


Plants from the genus Opuntia, particularly O. ficus-indica, are widely investigated from a chemical perspective. Opuntia is one of the most recognized generaus in the family Cactaceae because their fruits and cladodes are traditionally included in the human diet in several countries, and have a vast array of applications in food, pharmaceutical, and cosmetic industries. The performed studies have been focused in different parts of the plant including the pulp of the fruit (the edible part), but also their by-products (peels and seeds), the cladodes, and the flowers (Aruwa et al., 2018; El-Mostafa et al., 2014b; Ventura-Aguilar, Bosquez-Molina, Bautista-Baños, \& Rivera-Cabrera, 2017). Cactus plants contain a wide range of chemical constituents that are synthesized in response to biotic and abiotic factors. The main produced compounds produced-are polyphenols, alkaloids, betalains, terpenes, and fatty acids with nutritional value; also, those related to, and pharmacological and -food applications.

\subsection{Alkaloids}

Alkaloids are a widespread group of complex and diverse phytochemicals, which generally nitrogen-containing cyclic structures with, at least, one nitrogen atom (Mondal, Gandhi, Fimognari, Atanasov, \& Bishayee, 2019). Alkaloids are also a valuable class of secondary metabolites found in cactus plants that have been studied for over 100 years being mainly isoquinoline and phenethylamine derivatives (Cassels, 2019; del Socorro Santos-Díaz \& Camarena-Rangel, 2019). Alkaloids are one of the main groups of natural compounds present in plants that comprise one or more nitrogen atoms in their structure. Fifty phenethylamines and almost eighty isoquinolines have been detected in cactus plants. Mescaline, hordenine, N-methyltyramine, tyramine, and macromerine are some of the most commonly found alkaloids in these plants (del Socorro Santos-Díaz \& Camarena-Rangel, 2019). 
Phenethylamines have been much more investigated than isoquinolines that have attracted little interest. Among phenethylamines, mescaline and hordenine have been widely investigated due to their extraordinary hallucinogenic effects, among other interesting biological properties (Cassels, 2019). Mescaline is mainly found in Lophophora williamsii and L. diffusa, but also in Trichocereus pachanoi, T. peruvianus, and T. bridgesii, while hordenine appears in the genera Turbinicarpus, Mammillaria , and Ariocarpus (Cassels, 2019; del Socorro Santos-Díaz \& Camarena-Rangel, 2019).

\subsection{Phenolic}

Phenolic acids, flavonoids, and lignans, are the main phenolic compounds identified in plant species. These compounds can be classified based on the number and arrangement of their carbon atoms in several sub-classifications (Gutiérrez-Grijalva et al., 2018). Phenolic compounds comprise about 8000 structures and are classified in flavonoids (phenolic acids, lignans, stilbenes, tannins, among others.) and non-flavonoids (flavanols, flavones, flavonols, isoflavones, flavanones, and anthocyanins) (Manach, Scalbert, Morand, Rémésy, \& Jiménez, 2004). These compounds have a vast array of biological functions that are linked to their chemical structure comprising a benzene ring with at least one hydroxyl group attached to it.

Moreover, phenolic compounds are one of the most studied phytochemicals in cacti species (Table 2) due to their antioxidant activity and potential to prevent or delay the onset of noncommunicable diseases (del Socorro Santos-Díaz \& Camarena-Rangel, 2019). Phytochemical investigations reported distinct categories of polyphenols in cactus plants, such as phenolic acids, flavonoids, tannins, coumarins, lignans, stilbenes, among others. The occurrence of polyphenols is mainly reported in Opuntia species, particularly in O. ficusindica, but also in Hylocereus, Pereskia, Ariocarpus, and Coryphantha genera. 
Mena et al. (Mena et al., 2018), compared the phytochemical profile of young and old cladodes from $O$. ficus-indica and observed that young cladodes, which are consumed in some countries, contain the largest amounts of phenolics. The flavonol profiles of fruits and cladodes of different cultivars of $O$. ficus-indica from different countries, analyzed by HPLC-DAD, were similar (Moussa-Ayoub et al., 2014; Moussa-Ayoub, Youssef, El-Samahy, Kroh, \& Rohn, 2015). Results also showed that samples from peels and cladodes mainly contained isorhamnetin glycosides that were not detected in pulps.

The flowers $O$. ficus-indica were also chemically analyzed. Tunisian $O$. ficus-indica flowers contain lipids as linoleic, oleic, and palmitic acids; its essential oil is a complex monoterpene mixture with 29 components (Ouerghemmi et al., 2017). Besides, the RP-HPLC analysis allowed the identification of 20 phenolic compounds (phenolic acids and flavonoids) in the methanol extract. Phenolic acids and flavonoids were the main phenolic components identified by LC-ESI-MS in the methanol extract from flowers of the same species (Ammar et al., 2018). Overall, the extensive reports available indicate that polyphenols and betalains (betaxanthins and betacyanins) (Table 2) are the main compounds found in Opuntia species. However, they also contain fatty acids, coumarins, alkaloids, and terpenes, as well as carotenoids, amino acids, vitamins $\mathrm{C}$ and $\mathrm{E}$, fibers, polysaccharides, sterols, and esters (Aruwa et al., 2018).

Recently, Kivrak et al. (Kıvrak, Kıvrak, \& Karababa, 2018), investigated the phenolic composition of fruits of two other Opuntia species, O. robusta, and Opuntia ficus-barbarica, UPLC-ESI-MS/MS. Nineteen compounds were detected with some variations between both species; for instance, syringic acid was only detected in O. robusta and trans-cinnamic acid in $O$. ficus-barbarica; however, ferulic acid was found in both species. The fruits of $O$. dillenii (Ker Gawl) have been reported with betalains and polyphenols (Betancourt, CejudoBastante, Heredia, \& Hurtado, 2017). Also, the phenolic content of Opuntia fruits might be 
species-dependant, as some reports show that the chemical profile of Opuntia fruits is affected by different factors, like the ripening stage (Pinedo-Espinoza et al., 2017), drying methods (Gouws, D'-Cunha, Georgousopoulou, Mellor, \& Naumovski, 2019), storage conditions and duration (Cruz-Bravo, Guzmán-Maldonado, Araiza-Herrera, \& Zegbe, 2019).

\subsection{Natural pigments}

Betalains are classified as polar chromo-alkaloid nitrogenous pigments that are the central group of compounds produced by cactus plants that are mainly described in the Opuntia genus (Hussain, Sadiq, \& Zia-Ul-Haq, 2018) (Table 2) but are also present in other genera like Hylocereus, Mammillaria, Schlumbergera, among other. Betalains are natural pigments with ionizable carboxyl groups and a positive charge on the nitrogen molecule, with many applications for food, cosmetic, and pharmaceutical industries (Kaur, Thawkar, Dubey, \& Jadhav, 2018; Rahimi, Abedimanesh, Mesbah-Namin, \& Ostadrahimi, 2019).

Albano et al. (Albano et al., 2015), analyzed the betacyanin and phenolic contents in fruits of two varieties of O. ficus-indica fruits (edible part) from Apulia (South Italy). Results showed that betacyanin and phenolic contents were significantly greater in the purple variety in comparison with the orange variety. Also, Jiménez-Aguilar et al. (Jiménez-Aguilar, LópezMartínez, Hernández-Brenes, Gutiérrez-Uribe, \& Welti-Chanes, 2015), observed that total betalains (betaxanthins and betacyanins) and phenolic contents varied considerably in fruit pulps of different Mexican varieties of this species. Additionally, HPLC-PDA analysis did not detect flavonoids in the pulp and juice of these varieties.

A recent UHPLC-ESI-MS $^{n}$ analysis led to the identification of 41 compounds (betalains and mainly polyphenols) in the pulp of this species from Spain (Mena et al., 2018). A significant part of the compounds (23 compounds) was described for the first time and included flavonoids. According to these authors, these inconsistencies in the flavonoid profile 
can be explained by geographic and genotypic factors but also by the sensitivity and accuracy of the techniques used. Recently, the betalain profile of fruits of this species, of different colors, collected in Messina (Italy), was analyzed by RP-LC-DAD-MS/MS (Smeriglio et al., 2019). In total ${ }_{2} 5$-five betaxanthins and 4 four betacyanins were found, and considerable differences were observed in betalains profile depending on the fruit color, which affected their biological activity.

Previous investigations reported the chemical composition of fruits by-products, peels, and seeds. Melgar et al. (Melgar et al., 2017), identified phenolic and betalain compounds in hydroethanolic extracts from peels of $O$. ficus-indica var. sanguigna and gialla, and $O$. engelmannii. Twelve phenolic compounds, 2 two phenolic acids (piscid and eucomic acids), and 10-ten flavonoids (isorhamnetin, quercetin, and kaempferol derivatives) were identified, and $O$. engelmannii had the highest concentration of these compounds, being isorhamnetin$O$-(deoxyhexosyl-hexoside) the major compound found in this species. Also, 7 seven betalain compounds were identified, 2 two betaxanthins, and 5 five betacyanins. Betaxanthins were only found in $O$. ficus-indica varieties, while $O$. engelmannii contained the largest amounts of betacyanins.

Recently, Smeriglio et al. (Smeriglio et al., 2019), observed that peels of this species contain higher amounts of betacyanins while pulps contain higher amounts of betaxanthins. According to Jiménez-Aguilar et al. (Jiménez-Aguilar et al., 2015), the peel is the most valuable fraction of this species since it contains the highest levels of phenolic compounds, betalains as well as soluble dietary fiber, and has higher antioxidant activity. The results obtained indicated that fruit peels, usually considered a waste product, are a good source of bioactive molecules, particularly polyphenols, which can be used in combination with the pulp to prepare juice with great functional properties. 


\subsection{Other compounds}

Terpenes were also described in several parts (e.g., seeds, cladodes, stems, fruits) of cactus plants from different genera, namely Opuntia, Pereskia, Echinopsis, Hertrichocereus, Machaerocereus. Terpenes are the most abundant class of secondary metabolites usually stored in trichomes, and their structure contains five-carbon isoprene units gathered to each other in numerous ways. In addition to the compounds mentioned above other classes of compounds as saponins and sterols have been detected in cactus plants (Kakuta et al., 2012; Okazaki et al., 2011; Okazaki, Kinoshita, Koyama, Takahashi, \& Yuasa, 2007; Salazar \& Céspedes, 2013).

Some studies have also been performed concerning the phytochemical analysis of Opuntia seeds, principally of oil composition. Recently, Ciriminna et al. (Ciriminna, Delisi, Albanese, Meneguzzo, \& Pagliaro, 2017), showed that the seeds oil from O. ficus-indica and O. dilleniid is rich in unsaturated fatty acids. GC-MS examined tThe lipid composition of $O$. ficus-indica seeds from Algeria-was examined by GC-MS, - and several fatty acids were detected being linoleic $\operatorname{acid}_{2}$ the major one (Benattia, Arrar, \& Dergal, 2019). The Opuntia cladodes have also been studied as a source of bioactive molecules (El-Mostafa et al., 2014b; Mena et al., 2018; Moussa-Ayoub et al., 2014; Msaddak et al., 2017; Rocchetti, Pellizzoni, Montesano, \& Lucini, 2018).

Pereskia is another genus among Cactaceae family and some species such as Pereskia aculeata Mill., Pereskia grandifolia $\mathrm{Haw}_{2}$ and Pereskia bleo (Kunth) DC., are used in traditional medicine in some countries (e.g., Brazil, Bolivia, Malaysia, and Singapore) to threat several ailments (Pinto \& Scio, 2014; Zareisedehizadeh, Tan, \& Koh, 2014). Moreover, some plants are consumed as food, as is the case of P. aculeata (J. A. A. Garcia et al., 2019). Phytochemical studies indicate that plants from this genus contain mainly phenolics, alkaloids, sterols, terpenoids, fatty acids, and carotenoids (Pinto \& Scio, 2014; 
Zareisedehizadeh et al., 2014). P. aculeata is one of the most studied species from this genus. Souza et al. (L. F. Souza et al., 2014), found 30 compounds in the essential oil from leaves of this species and $_{1} 15$ on P. grandifolia leaves being in both cases predominantly oxygenated diterpenes. Phytol and manool oxide were the major compounds found in $P$. aculeata and $P$. grandifolia, respectively.

Another study allows the identification of 24 compounds in the essential oil from $P$.

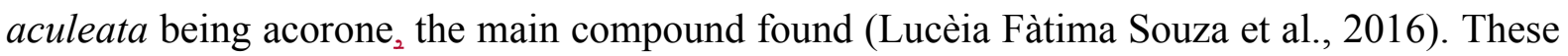
differences in the oil composition can be related with to different factors, namely environmental conditions, site and harvest period, plant age, and the method used to isolate the essential oil, among others.etc. Recently, Garcia et al. (J. A. A. Garcia et al., 2019), investigated the phenolic profile of leaf extract from this species by LC-DAD-ESI/MS ${ }^{\mathrm{n}}$ and identified 10 -ten compounds, including two phenolic acids and 8 eight flavonoids. Caftaric acid was the main compound ( $49 \%$ of the phenolic content), but the extract also contained considerable amounts of quercetin-3-O-rutinoside (14.99\%) and isorhamnetin-O-pentoside$O$-rutinoside $(9.56 \%)$. Berries and leaves of some Pereskia species have also been reported as a source of carotenoids with health-promotion effects, which can also be used as important biomarkers in these species (Agostini-Costa, Pêssoa, Silva, Gomes, \& Silva, 2014).

Besides the plants from the genus Opuntia and Pereskia that are the most interesting and investigated cactus plants from a phytochemical point of view, there are-other genera are producing interesting bioactive compounds, mainlynamely Lophophora, Coryphantha, Hylocereus, and Echinopsis, Turbinicarpus, ete. As previously mentioned, Lophophora plants are valuable sources of alkaloids (Cassels, 2019; del Socorro Santos-Díaz \& Camarena-Rangel, 2019), and Echinopsis spp. contain triterpenoid saponins (Okazaki et al., 2011). The fruits of Hylocereus (e.g., H. undatus, H. polyrhizus), Stenocereus, and Mammillaria have been reported for their contents in betalains and phenolics (Fathordoobady, 
Manap, Selamat, \& Singh, 2019; García-Cruz, Dueñas, Santos-Buelgas, Valle-Guadarrama, \& Salinas-Moreno, 2017; Li et al., 2019; Wu et al., 2019; Wybraniec \& Nowak-Wydra, 2007).

Metabolic profiling of pulp and peel of the fruits of $H$. polyrhizus (pitaya) at 9-nine different developmental stages was studied using an untargeted approach ${ }_{2}$ including GC-MS and LC--MS analysis (Wu et al., 2019). It was observed that betalain content increased noticeably during ripening. The peels contained more betaxanthin than betacyanin, and the opposite was observed for the pulps. The results obtained by these authors demonstrated that overall, the content of amino acids, soluble sugars, organic acids, and secondary metabolites in pulp was greater than in peel. Using supercritical fluid extraction (SFE) Fathordoobady et al. (Fathordoobady et al., 2019), optimized the extraction of betacyanins and observed that the obtained extract contained both acylated and non-acylated betacyanins. The use of cold plasma treatment stimulates the production of phenolics (mainly phenolic acids) on fruits of H. undatus as well as their antioxidant activity (Li et al., 2019).

García-Cruz et al. (García-Cruz et al., 2017), investigated the betalains and phenolic profiles of fruits of two Stenocereus spp. $\left(-, S\right.$. pruinosus $s_{2}$ and S. stellatus $)$. The betalain profile was similar for both species, but the pattern was different from that observed for Hylocereus spp. and Opuntia spp. The phenolic profile includes hydroxycinnamoyl derivatives, flavonols, and flavanones; S. stellatus is richer in phenolic compounds than S. pruinosus. Turbinicarpus spp. produce bioactive compounds, particularly alkaloids with hallucinogenic properties. Recently, Kim et al. (D. H. Kim et al., 2019), observed that in vitro cultures of T. valdezianus produce carotenoids, tocopherols, fatty acids, and phenolics. In vitro cultures have been used to overcome the constraints of traditional propagation methods observed in some cactus plants, such as the low growth rates, and are effective for bioactive compounds production (D. H. Kim et al., 2019; Robles-Martínez et al., 2016). 


\section{Extraction and isolation of bioactive compounds from Cactus plants}

Extraction is an important stage in the search and recovery of plant compounds and can be a hard task due to the complexity of plant tissues and the properties of plant compounds. Thus, the choice of the suitable extraction approach and the optimization of extraction conditions are very important. The extraction methods can be separated into conventional (e.g., maceration, Soxhlet, and percolation using extraction solvents usually organic) and modern (e.g., ultrasound-, microwave-, and enzyme-assisted extraction, and suband supercritical fluid extraction). Conventional methods usually involve long extraction periods, the consumption of high volumes of harmful solvents, and usually allow low extraction yields (Wen, Zhang, Sun, Sivagnanam, \& Tiwari, 2019). The modern techniques require shorter periods for extraction, a lower amount of solvents, and normally are more effective in terms of extraction yield and quality of the product obtained.

The vast literature available shows that the conventional extraction methods using organic solvents are the most frequently used for the extraction of bioactive compounds from cactus plants (fruits pulp and peel, seeds, cladodes, leaves, and flowers), although there also reports on the use of advanced techniques like SFE (Fathordoobady et al., 2019; Sharif et al., 2015), ultrasound-assisted extraction (Espinosa-Muñoz et al., 2017), and sonication (Mena et al., 2018; Moussa-Ayoub et al., 2014).

Numerous reports described the extraction of bioactive molecules, mainly betalains and phenolics, from fruits of Opuntia spp. using solvents like acetone (K1vrak et al., 2018), ethanol:_formic acid:_water (50:5:45 v/v/v) (Albano et al., 2015), methanol:_water (60:40) (Betancourt et al., 2017), methanol (80\%) acidified with formic acid (1\%) (Mena et al., 2018), among other. Kivrak et al. (Kivrak et al., 2018), used acetone to extract phenolics from pulps of two Opuntia species, O. robusta, and O. ficus-barbarica, combining maceration and ultrasonic extraction. An approach involving the purification and fractionation of extracts 
from another Opuntia spp. fruits, O. dillenii, obtained by maceration with methanol:_water (60:40) for $24 \mathrm{~h}$ and at $10{ }^{\circ} \mathrm{C}$, was used to analyze the betalainic and phenolic profile by HPLC-DAD-ESI-MS (Betancourt et al., 2017). This approach comprising the precipitation of hydrocolloids and proteins, and the fractionation on $\mathrm{C} 18$ column allows the identification of a larger number of compounds including new betalains [betacyanins: 17-decarboxybetanin and 17-decarboxyisobetanin, 6'-O-sinapoyl-O-gomphrenin and $6^{\prime}-O$-sinapoyl-O-isogomphrenin, 2'-O-apiosyl-4-O-phyllocactin and 5"-O-E-sinapoyl-2'-apiosyl-phyllocactin; betaxanthins: tryptophan-betaxanthin and tyrosine-betaxanthin (portulacaxanthin II) and phenolics (isoramnethin-3-glucuronide and quercetin-3-O-glucoside)].

DueOw toing the health-- promoting properties and applications of betalains from Opuntia spp. several works have been focused on the use of methodologies to separate, concentrate, and purify these bioactive compounds. As an example, Tamba et al. (Tamba, Servent, Mertz, Cissé, \& Dornier, 2019), recently prove the effectiveness of microfiltration and ultra or nanofiltration to separate betacyanins from $O$. dillenii juice.

With the aim of exploring Opuntia by products,-Melgar et al. (Melgar et al., 2017), prepared a hydroethanolic (ethanol: water, 80:20 v/v) extract by stirring Opuntia by-products to analyze the phenolic and betalain profile in peels of $O$. ficus-indica var. sanguigna and $O$. engelmannii. Several compounds were found (Table 2), and some differences in the profiles and biological properties were observed between varieties and species. The authors concluded that peels of these species are an important source of phytochemicals with health benefits. More recently, sonication was also used for the recovery of phenolics from O. ficusindica fruit peels (Mena et al., 2018).

Ouerghemmi et al. (Ouerghemmi et al., 2017), studied the effect of solvents with increased polarity (methanol, ethanol, acetone, methanol/ethanol/acetone, chloroform, and petroleum ether) on the recovery of phenolic compounds from O. ficus-indica flowers 
obtained by stirring, observing that methanol allows the recovery of higher contents of phenolics. Lately, different solvents (water, methanol, acetonitrile, acetone, ethyl acetate, dichloromethane, and hexane) and two extraction techniques (maceration and soxhlet) were tested to extract phenolics from O. ficus-indica flowers (Ammar et al., 2018), where soxhlet extraction and methanol showed the highest extract yield, total phenolic and flavonoid contents, and antioxidant activity.

There are also reports on the extraction of seed oil from cactus plants, mainly Opuntia spp., using conventional and emerging techniques. The conventional method requires the use of Soxhlet extraction with solvents like hexane and cyclohexane. Cyclohexane and a soxhlet extractor were recently used to isolate seed oil from O. ficus-indica (Benattia et al., 2019). Koubaa et al. (Koubaa et al., 2017), compared the composition and biological properties of $O$. stricta seed oil recovered by SFE and conventional Soxhlet extraction with hexane. Although similar extraction yields were obtained, the oil recovered by SFE contained higher amounts of total phenolics, more compounds identified (45 and 11 in SFE and Soxhlet, respectively), and higher antioxidant and antimicrobial properties. Ultrasound-assisted extraction showed to be less effective than conventional techniques to extract seed oil from two O. ficus-indica (Loizzo et al., 2019; Ortega-Ortega et al., 2017).

Overall, the reviewed reports on the extraction of chemical compounds from plants of the genus Opuntia, particularly from O. ficus-indica, and bioactivity tests, indicate that extracts from these species contain many bioactive molecules and showed important biological properties valuable for many applications. Lately, a new bioactive flavonol, opuntiol (6-hydroxymethyl-4-methoxy-2H-pyran-2-one), was isolated from this species, adequately characterized (FT-IR, ${ }^{1} \mathrm{H}$ and ${ }^{13} \mathrm{C} \quad \mathrm{NMR}$ spectroscopy), and showed antiproliferative activity (Veeramani Kandan et al., 2019). 
In addition to the Opuntia genus, the recovery of bioactive molecules has also been conducted with plants from other genera of cactus plants. Souza et al. (Lucèia Fàtima Souza et al., 2016), investigated the effect of successive extraction with solvents of increasing polarity (petroleum ether, chloroform, and methanol) on phenolic contents and biological activity (antioxidant and antimicrobial) of $P$. aculeata leaves. The highest phenolic amount and antioxidant properties were obtained in the methanol extract. On the other hand, the petroleum ether extract displayed great antibacterial activity against Escherichia coli, chloroform extract against Bacillus cereus and Staphylococcus aureus, and the petroleum ether withand methanol extracts against Aspergillus versicolor. Lately, ten phenolic compounds were identified in an ethanolic (70\%) extract from this species prepared by agitation at room temperature (J. A. A. Garcia et al., 2019). This extract displayed antioxidant and antimicrobial effects.

Sharif et al. (Sharif et al., 2015), optimized the use of SFE for the recovery of antioxidant compounds from leaves of another Pereskia spp., P. bleo, using carbon dioxide as solvent and ethanol as a modifier and observed that this method increased extraction efficiency of $\alpha$-tocopherol, $\beta$-sitosterol, and erythritol. SFE (with $\mathrm{CO}_{2}$ and ethanol/water as co-solvent) was also used for the recovery of betacyanins from $H$. polyrhizus fruit peels (Fathordoobady et al., 2019). The influence of several parameters was investigated, and the best conditions were optimized using a mathematical model. There are some reports on the isolation and structure characterization of saponins from cactus plants such as from the genera Isolatocereus, Stenocereus, Echinopsis, and Polaskia (Fujihara, Takahashi, Koyama, \& Kinoshita, 2017; Kakuta et al., 2012; Okazaki et al., 2011; Okazaki et al., 2007). For instance, Fujihara et al. (Fujihara et al., 2017), isolated several saponins from Polaskia chichipe Backbg., some of them for the first time, and showed good effects on the melanogenesis of melanoma cells. 


\section{Pharmacological properties of active constituents from Cactus plants}

Cactus plants were scientifically reported for various biological activities such as antimicrobial, antioxidant, antidiabetic, hepato-protective, wound healing, anti-cancer, antiviral, anti-obesity, cardiovascular, neuroprotective, and other activities. Some of their important activities are discussed below (Table 3).

\subsection{Antimicrobial potential}

The immature and mature cladode extract of $O$. ficus-indica exhibited antimicrobial activity against both Gram-negative (Escherichia coli, Salmonella enterica ser. Typhimurium, Enterobacter aerogenes) and Gram-positive bacteria (Enterococcus faecalis, Staphylococcus aureus). The minimum inhibitory concentration (MIC) value ranged between 700 to 1500 $\mu \mathrm{g} / \mathrm{ml}$ for immature and 1000 to $2000 \mu \mathrm{g} / \mathrm{ml}$ for mature cladode extract, respectively. The cladode extract exhibited antibiofilm activity against the strong biofilm producer, Staphylococcus aureus (Blando, Russo, Negro, De Bellis, \& Frassinetti, 2019).

The fruit extracts of O.dillenii (Ker Gawl.) Haw demonstrated antibacterial potential against three Gram-positive (B. subtilis, M. lysodeikticus, and E. faecalis) and three Gramnegative (K. pneumoniae, E. coli, and P. fluorescens) bacterial strains, with MIC values between 0.63 and $2.5 \mathrm{mg} / \mathrm{ml}$. However, the extracts of $O$. dillenii seeds showed the lowest overall antifungal MIC values, in a range from 0.16 to $2.5 \mathrm{mg} / \mathrm{ml}$ for Candida albicans, Trichoderma harzianum, Penicillium cyclopium, Aspergillus niger, Doratomyces stemonitis, Phialophora fastigiata, Fusarium oxysporum (Katanić et al., 2019).

Seed oils from $O$. albicarpa and $O$. ficus-indica exhibited antibacterial activities against Escherichia coli, Staphylococcus aureus, Listeria monocytogenes, Pseudomonas aeruginosa and antifungal activity against Saccharomyces cerevisiae and Candida albicans 
(Ramírez-Moreno et al., 2017). The antimicrobial activity may be attributed to the potential of these extracts to disrupt membrane or inactivating microbial adhesion or transport proteins. The xoconostle (O. oligacantha) extract could also actively inhibited Salmonella typhimurium growth (Cenobio-Galindo et al., 2019).

The aqueous ethanolic leaf extract of Pereskia aculeata Miller exhibited antimicrobial activity against both Gram (-) bacteria (Escherichia coli, Klebsiella pneumoniae, Morganella morganii, Proteus mirabilis, and Pseudomonas aeruginosa with MIC value of 20, 5, 20, >20, and $20 \mu \mathrm{g} / \mathrm{ml}$ respectively) and Gram (+) bacteria Enterococcus faecalis, Listeria monocytogenes, Methicillin-resistant Staphylococcus aureus with MIC value of 10, 5, and 5 $\mu \mathrm{g} / \mathrm{ml}$ respectively) (J. A. Garcia et al., 2019). The chloroform and methanolic leaf extract of P. aculeate also reported for their potential to inhibit the growth of Staphylococcus aureus and Pseudomonas aeruginosa, respectively (Lucèia Fàtima Souza et al., 2016). The methanolic leaf extract of Pereskia grandifolia exhibited antibacterial activity against Pseudomonas aeruginosa, Staphylococcus aureus, and Bacillus subtilis (Philip et al., 2009). The methanolic and ethyl acetate leaves extracts of Pereskia bleo exhibited antibacterial activity against $P$. aeruginosa, whereas its dichloromethane extract was effective against methicillin-resistant S. aureus (Malek, Shin, Wahab, \& Yaacob, 2009).

\subsection{Antiviral potential}

The methanolic fruit extract of $O$. dillenii exhibited antiviral activity against herpes simplex $1(\mathrm{EC} 50=25 \mu \mathrm{g} / \mathrm{mL})$ and $2\left(\mathrm{EC}_{50}=20 \mu \mathrm{g} / \mathrm{mL}\right)$, vaccinia $(\mathrm{EC} 50=100 \mu \mathrm{g} / \mathrm{mL})$ and moderate activity against vesicular stomatitis virus, coxsackievirus, respiratory syncytial virus, feline coronavirus, feline herpes virus, para-influenza virus, reo virus-1, sindbis virus and puntatoro virus $\left(\mathrm{EC}_{50}=>100 \mu \mathrm{g} / \mathrm{mL}\right)$ (Jang, Kumar, Ganesh, \& Peng, 2014). Gentile et al. (Gentile, Tesoriere, Allegra, Livrea, \& D'Alessio, 2004), demonstrated the antiviral 
activity of stem extract of $O$. ficus-indica against several DNA and RNA viruses. The cladode extract of $O$. streptacantha demonstrated antiviral activity against both DNA and RNA virus, herpes simplex, equine herpes, pseudorabies, influenza, respiratory syncytial, and human immunodeficiency virus. The extract inhibited intracellular virus replication and inactivated extracellular virus (Ahmad, Davies, Randall, \& Skinner, 1996).

\subsection{Antioxidant capacity}

The immature and mature cladode extract of virus ficus-indica exhibited antioxidant activity by both in vitro assays (Oxygen Radical Absorbance Capacity, ORAC) and Trolox equivalent antioxidant capacity, TEAC) and by cellular assay (cellular antioxidant activity in red blood cells, CAA-RBC). The TEAC values for mature and immature cladodes extracts were reported as 8.23 and $12.55 \mu \mathrm{mol} \mathrm{TE} / \mathrm{g}$ dry weight along with 70.85 to $92.87 \mu \mathrm{mol}$ $\mathrm{TE} / 100 \mathrm{~g}$ fresh weight respectively. Similarly, the ORAC values for mature and immature cladode extracts were demonstrated as 70.85 to $92.87 \mathrm{mmol} \mathrm{TE} / \mathrm{g}$ dry weight and 2.47 to 6.52 mmol TE/100g fresh weight, respectively (Blando et al., 2019).

The hydroalcoholic extracts of $O$. ficus-indica showed DPPH scavenging potential along with the better capacity to reduce $\mathrm{Fe}^{2+}$ ions (Benattia \& Arrar, 2018). The fruit juice of O. ficus-indica exhibited a protective effect in the erythrocytes membrane by decreasing malondialdehyde (MDA) and increasing of glutathione (GSH) level against the ethanolinduced rat in a dose-dependent manner. The protective effect may be attributed to the presence of several phytochemical compounds, including polyphenols, flavonoids, ascorbic acid, carotenoids, and betalains (Alimi, Hfaeidh, Bouoni, Sakly, \& Ben Rhouma, 2012). In another study, Alimi et al. (Alimi, Hfaeidh, Bouoni, Sakly, \& Rhouma, 2013) also demonstrated that the administration of $O$. ficus-indica juice could protect lipid and protein oxidation against ethanol-induced rat erythrocytes. The effect is attributed to the inhibition of 
ethanol-induced free radicals in rat erythrocytes or enhancement of endogenous antioxidants activities.

The by-products obtained from cladodes and fruits of $O$. ficus-indica exhibited antioxidant potential as studied by ABTS and FRAP assays (Bensadón, Hervert-Hernández, Sáyago-Ayerdi, \& Goñi, 2010). The fruit juice of Sicilian cultivars of prickly pear (O. ficus indica (L.) Mill.) showed antioxidant activity in the DPPH test. The antioxidant potential is attributed mainly to the presence of phenolic compounds like ferulic acid, rutin, and isorhamnetin, etc. that are effective radical scavengers (Enza Maria Galati et al., 2003). The O. ficus indica $\mathrm{f}$. inermis methanol root extract could scavenge DPPH radical (Alimi et al., 2010).

Albano et al. (Albano et al., 2015), assayed the antioxidant potential of the cactus pear (O. ficus-indica (L.) fruit extracts by TEAC and ORAC assays. The administration of $O$. ficus-indica cladodes extracts exhibited a protective effect on oxidative lithium-induced damage in rats, as revealed by a significant increase in hepatic catalase (CAT), superoxide dismutase (SOD), and glutathione peroxidase (GPx) activities. The beneficial effect of cladode extract could be explained by the antioxidant capacity of its constituents (Ben Saad et al., 2017). The antioxidant activity may be attributed to the presence of phenolic substances present in cladode extract that exhibits free radical-scavenging activities by their reactivity as hydrogen- or electron-donating agents, as well as metal ion-chelating properties, preventing metal-induced free radical formation. Seed oils from O. albicarpa and O. ficusindica exhibited DPPH free radical scavenging properties (Ramírez-Moreno et al., 2017).

The fruit extracts of $O$. dillenii (Ker Gawl.) Haw demonstrated DPPH and ABTS radical scavenging activities, which may be attributed to the presence of various phytonutrients likeviz. vitamins, carotenes, ascorbate or glutathione, and phenolics, etc. (Katanić et al., 2019). Loizzo et al. (Loizzo et al., 2019), reported that seed oil extract of two 
different varieties of $O$. ficus-indica such as Sanguigna and Surfarina exhibited antioxidant activities as revealed by ABTS, DPPH, FRAP, and $\beta$-carotene bleaching tests. The antioxidant potential may be attributed to the high carotenoid and $\gamma$-tocopherol content. The xoconostle (O. oligacantha) extract was also used for the development of an active film that showed ABTS and DPPH scavenging potential with $29.11 \pm 0.48$ and $41.42 \pm 1.81 \mathrm{mg}$ EAA for ABTS and DPPH, respectively (Cenobio-Galindo et al., 2019).

Oral administration of fruit juice of $O$. ficus-indica to alloxanized diabetic rats increases levels of superoxide dismutase (SOD), reduced glutathione (GSH), leading to normalization of the antioxidative status of the diabetic rats (Abd El-Razek \& Hassan, 2011). The hydroalcoholic extract of $O$. elatior fruit showed antioxidant effect by scavenging DPPH radicals by $38.14 \%$ at $200 \mu \mathrm{g} / \mathrm{mL}$ concentration (Chintu et al., 2017). The antioxidant activity of methanolic fruit extracts of $O$. dillenii by $\mathrm{DPPH}$, hydrogen peroxide, and hydroxyl radicals scavenging method demonstrated a higher percentage of DPPH inhibition $\left(\mathrm{IC}_{50}\right.$ value of $58.7 \mu \mathrm{g} / \mathrm{mL})$, hydrogen peroxide $(131.1 \mu \mathrm{g} / \mathrm{mL})$ and hydroxyl radicals $(159.3 \mu \mathrm{g} / \mathrm{mL})$ scavenging potential (Kanungo \& Satapathy, 2014). The anti--inflammatory activities of ethanolic cladode extracts of $O$. stricta were assessed by different antioxidant assays such as DPPH, nitric oxide, hydrogen peroxide, and phosphomolybdenum. These properties make $O$. stricta a good choice as a complementary source to use against diseases that involve oxidative stress (Izuegbuna, Otunola, \& Bradley, 2019).

The aqueous ethanolic leaf extract of Pereskia aculeata Miller exhibited antioxidant activity by inhibiting $\mathrm{DPPH}, \mathrm{ABTS}, \mathrm{OH}$ radicals with $\mathrm{IC}_{50}$ values of $72.9,40.5$, and 373.5 $\mu \mathrm{g} / \mathrm{ml}$ respectively. The activity may be attributed to the presence of major phenolic constituents like caffeic acid derivatives, quercetin, kaempferol, and isorhamnetin glycoside derivatives (J. A. Garcia et al., 2019). In another study, Pinto et al. (Pinto et al., 2012), demonstrated the antioxidant potential of $P$. aculeate leaf extract by thin-layer 
chromatography DPPH bioautography analysis. Out of the different solvent fraction, the hexane fraction was most active due to higher phenolic content.

The methanolic leaf extract of $P$. aculeate exhibited antioxidant activity assessed by 44.99 Trolox/kg (da Silva et al., 2019; Silva, Seifert, Schiedeck, Dode, \& Nora, 2018) and DPPH scavenging activity (Lucèia Fàtima Souza et al., 2016). The ethyl acetate $\left(\mathrm{IC}_{50}=168\right.$ $\mu \mathrm{g} / \mathrm{ml})$, hexane $\left(\mathrm{IC}_{50}=244 \mu \mathrm{g} / \mathrm{ml}\right)$, methanol $\left(\mathrm{IC}_{50}=278 \mu \mathrm{g} / \mathrm{ml}\right)$, and ethanol $\left(\mathrm{IC}_{50}=540\right.$ $\mu \mathrm{g} / \mathrm{ml}$ ) extracts of Pereskia bleo leaves exhibited antioxidant activity as determined by DPPH scavenging assay (Hassanbaglou et al., 2012; Sim, Sri Nurestri, \& Norhanom, 2010). The methanolic extracts of cactus plant species viz. Boucerosea lasiantha, Caralluma adscendens var. attenuata, C.stalagmifera and C.longipetala exhibited DPPH scavenging activity with $\mathrm{IC}_{50}$ values 50, 37, 32, $27 \mu \mathrm{g} / \mathrm{ml}$ (Vajha, Amrutha, \& Audipudi, 2010).

\subsection{Antidiabetic potential}

Loizzo et al. (Loizzo et al., 2019), reported that seed oil extract of two different varieties of $O$. ficus-indica such as Sanguigna and Surfarina exhibited $\alpha$-amylase and $\alpha$ glucosidase enzyme inhibitory activity in a dose-dependent manner. Both the variety could inhibit the $\alpha$-amylase ( $\mathrm{IC}_{50} \mu \mathrm{g} / \mathrm{ml} 32.7$ to 61.4 ) and $\alpha$-glucosidase enzyme ( $\mathrm{IC}_{50} \mu \mathrm{g} / \mathrm{ml} 42.4$ to $88.5)$ to a different extent. Several studies have demonstrated the antidiabetic potential of $O$. ficus-indica. Oral administration of seed oil of $O$. ficus-indica decreased postprandial hyperglycemia levels in both healthy and STZ-induced and alloxan-induced diabetic rats (Berraaouan et al., 2015; Berraaouan et al., 2014). The antidiabetic effect can be attributed to the partial reduction of D-glucose intestinal absorption, free radicals quenching, and inhibition of pancreatic $\beta$-cells injuries. The oil containing linoleic acid and oleic acid may be responsible for the said activities. Similarly, several other studies have also demonstrated that boiled cactus stems and crude extracts of $O$. ficus-indica could reduce postprandial glycemia, 
serum insulin, and plasma glucose-dependent insulinotropic peaks in the diabetic patient (López-Romero et al., 2014; Roman-Ramos, Flores-Saenz, \& Alarcon-Aguilar, 1995).

In another study, aqueous and fruit skin and pulp extract of $O$. ficus-indica demonstrated a reduction in blood glucose levels in obese, prediabetic patients (Godard et al., 2010; Van Proeyen, Ramaekers, Pischel, \& Hespel, 2012). Hwang et al. (Hwang, Kang, \& Lim, 2017), also reported the $\alpha$-glucosidase enzyme inhibitory $\left(\mathrm{IC}_{50}\right.$ values of 67.33 and $86.68 \mu \mathrm{g} / \mathrm{ml}$ ) and hypoglycaemic potential of aqueous extract and dry powder of $O$. ficusindica in STZ-induced diabetic rats. Oral administration of fruit juice of $O$. ficus-indica to alloxanized diabetic rat leads to normalization of levels of glucose, cholesterol, urea, creatinine, aspartate aminotransferase (AST), alanine aminotransferase (ALT), alkaline phosphatase (ALP), and malondialdehyde (MDA) towards normal condition (Abd El-Razek \& Hassan, 2011).

In another study, the commercial product OpunDia capsule containing fruit skin and stem extracts of $O$. ficus-indica showed a significant decrease in acute blood glucose concentrations at 60,90 , and 120 min compared to preintervention blood glucose levels in 29 obese prediabetic male and female subjects (Godard et al., 2010). The hydroalcoholic extract of $O$. elatior fruit showed antidiabetic effect by inhibiting the $\alpha$-amylase enzyme up to $54.68 \%$ at $500 \mu \mathrm{g} / \mathrm{mL}$ concentration (Chintu et al., 2017). The methanolic cactus fruit extract of xoconostle (O. oligacantha) inhibited $\alpha$-amylase and $\alpha$-glucosidase enzymes both in vitro and under simulated intestinal conditions (Medina-Pérez et al., 2019).

Cenobio-Galindo et al. (Cenobio-Galindo et al., 2019) reported the presence of different nutraceuticals like rutin, ferulic acid, quercetin, apigenin, caffeic acid, kaempferol in xoconostle fruits contain might be responsible for its inhibitory effect over $\alpha$-amylase and $\alpha$ glucosidase enzymes. The juice of $O$. streptacantha exhibited $\alpha$-glucosidase inhibitory activity. The active component was reported as a derivative of (4-hydroxy)-phenyl acetic acid 
(Becerra-Jiménez \& Andrade-Cetto, 2012). Similarly, two liquid and filtered extracts In another study, liquid extract and a filtered extract of $O$. streptacantha exhibited an antihyperglycemic effect in streptozotocin (STZ)-diabetic rats by blocking the hepatic glucose output (Andrade-Cetto \& Wiedenfeld, 2011). Also, tThe methanolic extracts of cactus plant species viz. Boucerosea lasiantha, Caralluma adscendens var. attenuata, $C$. stalagmifera ${ }_{2}$ and $C$. longipetala exhibited antidiabetic activities by inhibiting $\alpha$ - amylase enzyme (Vajha et al., 2010). The leaf, stem, and root aqueous extract of Pereskia bleo at $500 \mathrm{mg} / \mathrm{kg}$ decreased fasting plasma glucose levels by $66 \%, 65 \%$, and $58 \%$, respectively, in alloxanized diabetic rats. It also showed decreased levels in total cholesterol, triglycerides, and restored the HDL level (Mat Darus \& Mohamad, 2017).

\subsection{Hepatoprotective activity}

O. ficus-indica cladode extract showed hepatoprotective potential against lithiuminduced hepatic injury in rats. The histopathological changes in the liver, such as sinusoidal dilation, congested central veins, vacuolization, and inflammatory cell infiltration caused by lithium poisoning, were reduced upon feeding with cladodes extract to the rat. Administration of cladode extract significantly increased the hepatic CAT, SOD, and GPx activities (Ben Saad et al., 2017). The aqueous extract from cladodes $(2 \mathrm{~mL} / \mathrm{kg})$ decreased the AST and ALT levels in the $\mathrm{CCl}_{4}$-induced hepatotoxic Wistar male rats (Djerrou et al., 2015). Oral administration of fruit juice of $O$. ficus-indica (Prickly Cactus Pear) to alloxanized diabetic rats protect and restore the damages of the liver, showing the hepatoprotective potential of the extract in diabetic rats (Abd El-Razek \& Hassan, 2011). Polysaccharides extracted from $O$. ficus-indica showed protective effects in the liver from organophosphorus pesticides (Ncibi, Othman, Akacha, Krifi, \& Zourgui, 2008). 
The fruit juice of $O$. robusta and $O$. streptacantha extracts exhibited hepatoprotective effect against acetaminophen (APAP)-induced acute liver failure (ALF) male Wistar rat model. Both extracts significantly attenuated APAP-induced injury markers AST, $\mathrm{ALT}_{2}$ and ALP, and improved liver histology. $O$. extracts significantly reduced leakage of LDH and cell necrosis in cultured hepatocytes (González-Ponce et al., 2016). The aqueous ethanolic leaf extract of Pereskia aculeata Miller showed no hepatotoxicity against liver primary culture PLP2 at a concentration of $400 \mu \mathrm{g} / \mathrm{ml}$ (J. A. Garcia et al., 2019). Similar studies were also carried out by Pinto and Scio (Pinto \& Scio, 2014), demonstrating the absence of toxicity of Pereskia sp. for humans or animals.

\subsection{Cytotoxic activity}

The cytotoxic potential of the fruit extracts of $O$. dillenii (Ker Gawl.) Haw was demonstrated on human breast cancer cells (MCF-7), human colon cancer cells (LoVo), and human hepatocytes (HepG2) by MTT assay. The study revealed that the extract showed a low cytotoxic effect against the cancer cell lines (Katanić et al., 2019). In another study, methanolic fruit extract of $O$. dillenii exhibited cytotoxicity activity against HeLa, CRFK, and Vero cell lines above $100 \mu \mathrm{g} / \mathrm{ml}$ (Jang et al., 2014). The cytotoxic activities of cladode extracts of $O$. stricta were reported in U937 and Jurkat cell lines by MTT assay. The study displayed the cytotoxic effect of acetone extract of dried cladode with IC50 was $110.1 \mu \mathrm{g} / \mathrm{ml}$ (Izuegbuna et al., 2019). The alkaloid extracts isolated from the dried plants of Opuntia polyacantha exhibited cytotoxic activity against MCF-7 and WRL-68 cell lines. The MTT assay demonstrated that the extracted alkaloids at $400 \mu \mathrm{g} / \mathrm{ml}$ concentration could inhibit MCF-7 and WRL-68 cells by 52.7 and 91.89\%, respectively (Abdulazeem, Al-Alaq, Alrubaei, Al-Mawlah, \& Alwan, 2018). 
The methanolic extract of Lophophora williamsii exhibited an immunomodulatory effect by activating nitric oxide production by murine macrophages and stimulated up to the 2.4fold proliferation of murine thymic lymphocytes. The extract also induced human leukocytes. The extract also exhibited cytotoxic effects against MCF7, L5178Y-R, U937, and L929 cell lines as confirmed by MTT assay (Franco-Molina et al., 2003). The aqueous methanolic stem extracts of Pachycereus marginatus exhibited in vitro cytotoxic effects against L5178Y-R lymphoma murine cells. The extract contains bioactive compounds like lophenol, $\beta$-sitosterol, and palmitic acid. Oral administration of aqueous extracts of $P$. marginatus to vincristineinduced mice demonstrated $60 \%$ survival without altering the liver parenchyma (GomezFlores et al., 2019). The hexane, dichloromethane, ethyl acetate, and methanol extracts of Pereskia bleo leaves exhibited cytotoxic activity against MCF-7, HT-29, and CEMSS cell lines after $72 \mathrm{~h}$ incubation time (Malek et al., 2009).

\subsection{Anti-inflammatory activity}

The alcoholic extracts of the flowers, fruits, and stems of $O$. dillenii was were reported for their anti-inflammatory activity (Ahmed, Tanbouly, Islam, Sleem, \& Senousy, 2005). The aqueous fruit extract also demonstrated analgesic and anti-inflammatory and antiinflammatory effects in the carrageenan-induced rat paw edema model (Loro, del Rio, \& Pérez-Santana, 1999). The methanolic stem extract of $O$. ficus-indica demonstrated antiinflammatory activity in adjuvant-induced chronic inflammation mice model. The active antiinflammatory principle was reported as $\beta$-sitosterol (Park, Kahng, Lee, \& Shin, 2001).

The anti-inflammatory activities of ethanolic cladode extracts of $O$. stricta were reported in RAW 264.7 cells by Cyclooxygenase 2 (COX-2) assay, and the study showed a decrease in COX-2 reduction of about 15\% (Izuegbuna et al., 2019). The methanolic extracts of cactus plant species viz. Boucerosea lasiantha, Caralluma adscendens var. attenuata, 
C.stalagmifera, and C.longipetala exhibited anti-inflammatory activity (5-Lox assay) with $\mathrm{IC}_{50}$ values $27,17,12.8,11.8 \mu \mathrm{g} / \mathrm{ml}$ (Vajha et al., 2010). The dichloromethane extracts of Pereskia bleo leaves exhibited anti-inflammatory activity in carrageenan-induced paw edema in rats (Qureshi, Afzal, \& Kin, 2019). The methanolic leaf extract of the Pereskia aculeate exhibited anti-inflammatory activity in acute and chronic ear dermatitis in mice model by reducing IL-6 and TNF- $\alpha$ cytokines levels (Pinto Nde et al., 2015).

\subsection{Anti-ulcer potential}

The powder of cladodes, as well as purified mucilage of $O$. ficus-indica 2 exhibited anti-ulcer activity against ethanol-induced ulcerative mice model (Maataoui, Maataoui, Almesrarm, \& Hilali, 2018). The ethanolic fraction of O. ficus-indica cladodes extract was effective in protecting the small intestine against MTX-induced damage in male Wistar rats. Treatment with $O$. ficus-indica extract caused a decrease in MDA level, peroxidase activities, and protein carbonyls generation along with an increase in CAT levels (Akacha, Rebai, Zourgui, \& Amri, 2018). The methanolic root extract of O. ficus-indica f. inermis demonstrated gastroprotective ability against an ethanol-induced ulcer in rats (Alimi et al., 2010). The lyophilized cladodes of O. ficus-indica were reported for their anti-ulcer potential in ethanol-induced ulcer in rats. The ultrastructural observations of gastric mucosa revealed the protective action of cladode against ethanol-induced ulcers. The protective effect may be due to the mucilage of O. ficus-indica (E. M. Galati, Monforte, Tripodo, d'Aquino, \& Mondello, 2001).

\subsection{Antigenotoxic activity}

The fruit extracts of $O$. dillenii (Ker Gawl.) Haw also exhibited antigenotoxic as it could protect DNA from the harmful effect of hydroxyl radicals (Katanić et al., 2019). 
Madrigal-Santillan et al. (Madrigal-Santillán et al., 2013), also reported the antigenotoxic effects of juice extract of $O$. ficus-indica as the extract could reduce the number of micronucleated polychromatic erythrocytes. In another study, Zorgui et al. (Zorgui, AyedBoussema, Ayed, Bacha, \& Hassen, 2009), reported the antigenotoxic potential of O. ficusindica cladodes extracts in terms of effective protection from the clastogenic action and DNA damages of zearalenone.

\subsection{Cardioprotective potential}

The randomized clinical trials (RCT) study indicated that supplementation with $O$. ficus indica decreased the percentage of body fat, blood pressure, and total cholesterol and cardiovascular risk factors (Onakpoya, O'Sullivan, \& Heneghan, 2015). Osuna-Martínez et al. (Osuna-Martínez, Reyes-Esparza, \& Rodríguez-Fragoso, 2014), reported the antiatherogenic properties of Opuntia spp, which may be due to the presence of their high polyphenols content, dietary fibers, and proteins that decreased lipid peroxidation. The cladodes of $O$. streptacantha var. cardona, tuna loca, O. hyptiacantha, O. megacantha, O. albicarpa inhibited LDL oxidation and foam cells formation by macrophages in a dose--dependent manner suggesting the role of Opuntia spp. in inhibiting atherogenesis in its earlier stages (Keller et al., 2015). In another study, Garoby-Salom et al. (Garoby-Salom et al., 2016), demonstrated that supplementation with $10 \mathrm{mg} / \mathrm{kg}$ powdered cladodes of $O$. streptacantha or O. ficus-indica for 15 weeks to apoE-KO mice reduced the development of atherosclerotic lesions significantly.

Consumption of prickly pears from $O$. robusta lowered the LDL cholesterol and 8epi-prostaglandin $\mathrm{F}_{2} \alpha$, an F2 isoprostane level (Budinsky et al., 2001). Another study revealed that ingestion $O$. robusta improved the platelet function and hemostatic balance and decreased atherosclerotic risk (Wolfram, Kritz, Efthimiou, Stomatopoulos, \& Sinzinger, 
2002). Consumption of $O$. ficus-indica dried leaves exhibited a rapid increase in HDL cholesterol levels concomitantly with a decrease in LDL cholesterol and triglycerides in women affected with metabolic syndrome, indicating the hypocholesterolemic effect of the plant (Linarès, Thimonier, \& Degre, 2007).

\subsection{Neuroprotective potential}

The polysaccharides isolated from O.dillenii exhibited neuroprotective activities against brain ischemia-reperfusion injury in rats under in vivo conditions-and. They reduced the oxidative stress-induced damage in the PC12 cells under in vitro conditions (X. Huang, Li, Li, \& Guo, 2009). The polysaccharide extracted from $O$._milpa also exhibited neuroprotective activity against cerebral cortex and hippocampal slices from $\mathrm{H}_{2} \mathrm{O}_{2}$-induced injury by normalization of neuroprotective biochemical markers like acetate dehydrogenase (LDH), superoxide dismutase (SOD), glutathione (GSH), and total antioxidant competence (T-AOC) level (Xianju Huang, Li, Guo, \& Yan, 2008). The ethanolic extract of stems of O. ficusindica var. saboten exhibited enhanced cognitive performance in mice by ameliorating scopolamine-induced cognitive dysfunction. Western blot analysis and the ex vivo study revealed that the extract increased the levels of phosphorylated extracellular signal-regulated kinase and cAMP response element-binding protein (CREB) and the levels of brain-derived neurotrophic factor (BDNF) expression in the hippocampus. It also inhibited AChE activity in the brain (Kwon et al., 2018).

The flavonoids quercetin, (+)-dihydroquercetin, and quercetin 3-methyl ether were isolated from the ethyl acetate fractions of the fruits and stems of $O$. ficus-indica var. saboten showed neuroprotective actions against the oxidative injuries induced in cortical cell cultures. These compounds inhibited lipid peroxidation and scavenged 1,1-diphenyl-2-picrylhydrazyl free radicals (Dok-Go et al., 2003). The methanol extract of O. ficus-indica also has a 
neuroprotective action against N-methyl-D-aspartate NMDA, kainate KA and OGD oxygen deprivation oxygen, inducing neuronal alterations in cultures of mouse cortical cells (J. H. Kim et al., 2006).

\section{Clinical trials on Cactus-related substances}

Different studies on cactus plants have revealed some relationship between ethnomedicinal uses and experimental results at in vitro and in vivo levels (del Socorro Santos Díaz, Barba de la Rosa, Héliès-Toussaint, Guéraud, \& Nègre-Salvayre, 2017). However, there are not enough pre-clinical and clinical studies to validate their pharmaceutical use. Although the Cactaceae family gathered around 1400-1500 species, only a few have been assessed for biological/pharmacological/beneficial attributes in clinical trials. Opuntia plants are the most-known and evaluated cactus (Table 4), so continuous programs to evaluate other plants are required to validate such effects recorded by cactus plants. In the case of chemopreventive actions, a study reported the cytotoxic activity of a crude extract and an isolated compound from Pereskia bleo, but a clinical trial is not mentioned (Malek et al., 2009).

O. ficus-indica (also called Nopal) is well-known for its health effects. However, few clinical trials evaluating O. ficus-indica have been reported. In this context, there is information that leaves and stems of prickly pear can reduce plasma glucose levels in animal studies (Butterweck et al., 2011). In humans, doses at 100-600 mg/day exhibited hypoglycemic effects in patients with type-2 diabetes mellitus (Cicero, Derosa, \& Gaddi, 2004). Although studies are scarce, their good profile of adverse reactions, together with the available efficacy data concerning reducing blood glucose levels, indicates that it is safe to conduct further studies. 
Additionally, Nopal fruit intake is generally suggested for healthy lifestyles, and its consumption may be part of a well-balanced diet (Onakpoya et al., 2015). According to the current clinical trials-derived information (Table 4), O. ficus-indica intake can cause substantial reductions in the percentage of body fat, total cholesterol, and blood pressure, beneficial for the body's redox cardiovascular balance, and type- 2 diabetes conditions. However, such trials vary in methodology, design, and results, and insufficient information is a marked feature of such trials. Further clinical trials to validate the effects of cactus plants are therefore required.

\section{Conclusions}

Cactus are noticeable components of arid and semi-arid regions of the World, where the population deals with the subsistence economies. Cactus, as a multifunctional plant, provides the opportunity of taking benefits from the whole plant: fruits, cladodes, flowers, and seeds. This plant can offer not only fresh food but also processed products to the society preserving its functional and medicinal potentials. During the last decade, the growing interest in cactus has resulted in a large number of scientific papers describing the conformation and the bioactivity of a whole extract and specific purified cactus compounds.

However, despite considerable research on its nutritional importance, medicinal uses, and food value, cacti remain to be an underutilized and unexploited crop. The variety of uses of cactus has immense potential to be an essential element of food and medicine in the future society. This review provides an overview of the habitat, classification, phytochemistry, chemical constituents, extraction and isolation of bioactive compounds, the nutritional and pharmacological potential that contribute to its action as a constituent of the antimicrobial, antioxidant, antidiabetic, anti-ulcer, cytotoxicity, cardioprotective, antigenotoxic, anti-inflammatory, hepatoprotective and neuroprotective effects in order to give the basis of their 
use in the prevention and cure of some chronic diseases. Besides, information on pre-clinical and clinical studies of different Cactus species have been discussed.

\section{Acknowledgements}

Authors-The authors are grateful to respective institutions for support. JK Patra G Das and HS Shin are grateful to Dongguk University, Republic of Korea for support. This work is supported by the National Research Foundation of Korea (NRF) grant funded by the Korea government Ministry of Science and ICT (2020R1G1A1004667), Republic of Korea. S Gonçalves and A Romano acknowledge the project INTERREG - MD.NET: When Brand Meets People and by National Funds through FCT - Foundation for Science and Technology under the Project UIDB/05183/2020. S Gonçalves is fundedfinanced by national funds through FCT, under the Norma Transitória - DL 57/2016/CP1361/CT0022. E. Coy-Barrera thanks the UMNG funding under the project IMP-CIAS-2942.

\section{Funding}

This work is supported by the National Research Foundation of Korea (NRF) grant funded by the Korea government Ministry of Science and ICT (2020R1G1A1004667), Republic of Korea.

\section{Conflict of Interest}

Authørs-The authors declare no conflict of interest with the manuscript.

\section{References}

Abd El-Razek, F., \& Hassan, A. (2011). Nutritional value and hypoglycemic effect of prickly cactus pear (Opuntia ficus-Indica) fruit juice in alloxan-induced diabetic rats. Australian Journal of Basic and Applied Sciences, 5(10), 356-377. 
Abdulazeem, L., Al-Alaq, F. T., Alrubaei, H. A., Al-Mawlah, Y. H., \& Alwan, W. K. (2018). Anti-cancer activity of Opuntia polyacantha alkaloid extract on human breast cancer cell line. Journal of Pharmaceutical Sciences and Research, 10(7), 1753-1754.

Adnan, M., Ullah, I., Tariq, A., Murad, W., Azizullah, A., Khan, A. L., \& Ali, N. (2014). Ethnomedicine use in the war affected region of northwest Pakistan. Journal of Ethnobiology and Ethnomedicine, 10, 16-16. doi:10.1186/1746-4269-10-16

Agostini-Costa, T. S., Pêssoa, G. K. A., Silva, D. B., Gomes, I. S., \& Silva, J. P. (2014). Carotenoid composition of berries and leaves from a Cactaceae - Pereskia sp. Journal of Functional Foods, 11, 178-184. doi:https://doi.org/10.1016/j.jff.2014.09.015

Ahmad, A., Davies, J., Randall, S., \& Skinner, G. (1996). Antiviral properties of extract of Opuntia streptacantha. Antiviral Research, 30(2-3), 75-85. doi:10.1016/01663542(95)00839-x

Ahmed, M. S., Tanbouly, N. D. E., Islam, W. T., Sleem, A. A., \& Senousy, A. S. E. (2005). Anti-inflammatory flavonoids from Opuntia dillenii (Ker-Gawl) Haw. flowers growing in Egypt. Phytotherapy Research, 19(9), 807-809. doi:10.1002/ptr.1708

Ahmet Sargin, S. (2015). Ethnobotanical survey of medicinal plants in Bozyazi district of Mersin, Turkey. Journal of Ethnopharmacology, 173, 105-126. doi:https://doi.org/10.1016/j.jep.2015.07.009

Ajayi, T., Moody, J., \& Anthony, C. (2019). Ethnobotanical Survey of Plants Used in the Management of Hypertension in Ibadan North Local Government Area of Oyo State, Nigeria. Nigerian Journal of Pharmaceutical Research, 15(1), 61-73.

Akacha, A., Rebai, T., Zourgui, L., \& Amri, M. (2018). Preventive effect of ethanolic extract of cactus (Opuntia ficus-indica) cladodes on methotrexate-induced oxidative damage of the small intestine in Wistar rats. Journal of Cancer Research and Therapeutics, 14(10), 779-784. doi:10.4103/0973-1482.174555

Al-Fatimi, M. (2019). Ethnobotanical survey of medicinal plants in central Abyan governorate, Yemen. Journal of Ethnopharmacology, 241, 111973. doi:https://doi.org/10.1016/j.jep.2019.111973

Alagesaboopathi, C. (2009). Ethnomedicinal plants and their utilization by villagers in Kumaragiri Hills of Salem district of Tamilnadu, India. African Journal of Traditional, Complementary, and Alternative Medicines : AJTCAM, 6(3), 222-227. doi:10.4314/ajtcam.v6i3.57157

Albano, C., Negro, C., Tommasi, N., Gerardi, C., Mita, G., Miceli, A., . . Blando, F. (2015). Betalains, Phenols and Antioxidant Capacity in Cactus Pear [Opuntia ficus-indica (L.) Mill.] Fruits from Apulia (South Italy) Genotypes. Antioxidants (Basel, Switzerland), 4(2), 269-280. doi:10.3390/antiox4020269

Aldunate, C., Villagrán, C., Armesto, J. J., \& Castro, V. (1983). Ethnobotany of pre-altiplanic community in the Andes of northern Chile. Economic Botany, 37(1), 120-135. doi:10.1007/BF02859312

Alimi, H., Hfaeidh, N., Bouoni, Z., Sakly, M., \& Ben Rhouma, K. (2012). Protective effect of Opuntia ficus indica f. inermis prickly pear juice upon ethanol-induced damages in rat erythrocytes. Alcohol, $46(3)$

235-243. doi:https://doi.org/10.1016/j.alcohol.2011.09.024

Alimi, H., Hfaeidh, N., Bouoni, Z., Sakly, M., \& Rhouma, K. B. (2013). Ameliorative effect of Opuntia ficus indica juice on ethanol-induced oxidative stress in rat erythrocytes. Experimental and Toxicologic Pathology, 65(4), 391-396. doi:https://doi.org/10.1016/j.etp.2011.12.003

Alimi, H., Hfaiedh, N., Bouoni, Z., Hfaiedh, M., Sakly, M., Zourgui, L., \& Rhouma, K. B. (2010). Antioxidant and antiulcerogenic activities of Opuntia ficus indica $\mathrm{f}$. inermis 
root extract in rats. Phytomedicine, 17(14), 1120-1126. doi:https://doi.org/10.1016/j.phymed.2010.05.001

Ammar, I., Ben Salem, M., Harrabi, B., Mzid, M., Bardaa, S., Sahnoun, Z., . . . Ennouri, M. (2018). Anti-inflammatory activity and phenolic composition of prickly pear (Opuntia ficus-indica) flowers. Industrial Crops and Products, 112, 313-319. doi:https://doi.org/10.1016/j.indcrop.2017.12.028

Amuri, B., Maseho, M., Simbi, L., Duez, P., \& Byanga, K. (2018). Ethnobotanical survey of herbs used in the management of diabetes mellitus in Southern Katanga Area/DR Congo. The Pan African medical journal, 30, 218-218. doi:10.11604/pamj.2018.30.218.11718

Anand, S., Velmurugan, G., \& Revathi, D. (2016). Survey of medicinal plants from Vadachennimalai Hill, Salem district of Tamil Nadu, India. Journal of Medicinal Plants, 4(3), 219-223.

Andrade-Cetto, A., \& Wiedenfeld, H. (2011). Anti-hyperglycemic effect of Opuntia streptacantha Lem. Journal of Ethnopharmacology, 133(2), 940-943. doi:https://doi.org/10.1016/j.jep.2010.11.022

Andrade, J. M., Lucero Mosquera, H., \& Armijos, C. (2017). Ethnobotany of Indigenous Saraguros: Medicinal Plants Used by Community Healers "Hampiyachakkuna" in the San Lucas Parish, Southern Ecuador. BioMed Research International, 2017, 93437249343724. doi:10.1155/2017/9343724

Arellano, E., \& Casas, A. (2003). Morphological variation and domestication of Escontria chiotilla (Cactaceae) under silvicultural management in the Tehuacán Valley, Central Mexico. Genetic Resources and Crop Evolution, 50(4), 439-453. doi:10.1023/A:1023902704131

Armijos, C., Cota, I., \& González, S. (2014). Traditional medicine applied by the Saraguro yachakkuna: a preliminary approach to the use of sacred and psychoactive plant species in the southern region of Ecuador. Journal of Ethnobiology and Ethnomedicine, 10, 26-26. doi:10.1186/1746-4269-10-26

Arquion, R. D., Galanida, C. C., Villamor, B., \& Aguilar, H. T. (2015). Ethnobotanical study of indigenous plants used by local people of Agusan del Sur, Philippines. Asia Pacific Higher Education Research Journal (APHERJ), 2(2).

Arshad, M., Ahmad, M., Ahmed, E., Saboor, A., Abbas, A., \& Sadiq, S. (2014). An ethnobiological study in Kala Chitta hills of Pothwar region, Pakistan: multinomial logit specification. Journal of Ethnobiology and Ethnomedicine, 10(1), 13. doi:10.1186/1746-4269-10-13

Aruwa, C. E., Amoo, S. O., \& Kudanga, T. (2018). Opuntia (Cactaceae) plant compounds, biological activities and prospects - A comprehensive review. Food Research International, 112, 328-344. doi:https://doi.org/10.1016/j.foodres.2018.06.047

Balakrishnan, V., Prema, P., Ravindran, K., \& Robinson, J. P. (2009). Ethnobotanical studies among villagers from Dharapuram taluk, Tamil Nadu, India. Global Journal of Pharmacology, 3(1), 08-14.

Barkatullah, Ibrar, M., Rauf, A., Ben Hadda, T., Mubarak, M. S., \& Patel, S. (2015). Quantitative ethnobotanical survey of medicinal flora thriving in Malakand Pass Hills, Khyber Pakhtunkhwa, Pakistan. Journal of Ethnopharmacology, 169, 335-346. doi:https://doi.org/10.1016/j.jep.2015.04.052

Barthlott, W., Burstedde, K., Geffert, J. L., Ibisch, P. L., Korotkova, N., Miebach, A., . . . Mutke, J. (2015). Biogeography and Biodiversity of Cacti. : Schumannia 7. .

Becerra-Jiménez, J., \& Andrade-Cetto, A. (2012). Effect of Opuntia streptacantha Lem. on alpha-glucosidase activity. Journal of Ethnopharmacology, 139(2), 493-496. doi:https://doi.org/10.1016/j.jep.2011.11.039 
Belayneh, A., Asfaw, Z., Demissew, S., \& Bussa, N. F. (2012). Medicinal plants potential and use by pastoral and agro-pastoral communities in Erer Valley of Babile Wereda, Eastern Ethiopia. Journal of Ethnobiology and Ethnomedicine, 8, 42-42. doi:10.1186/1746-4269-8-42

Belayneh, A., \& Bussa, N. F. (2014). Ethnomedicinal plants used to treat human ailments in the prehistoric place of Harla and Dengego valleys, eastern Ethiopia. Journal of Ethnobiology and Ethnomedicine, 10, 18-18. doi:10.1186/1746-4269-10-18

Ben Saad, A., Dalel, B., Rjeibi, I., Smida, A., Ncib, S., Zouari, N., \& Zourgui, L. (2017). Phytochemical, antioxidant and protective effect of cactus cladodes extract against lithium-induced liver injury in rats. Pharmaceutical biology, 55(1), 516-525.

Benattia, F. K., \& Arrar, Z. (2018). Antioxidative and Antiradical Activities of Bioactive Compounds of Extracts From Algerian Prickly Pear (Opuntia ficus-indica. L) Fruits. Current Nutrition \& Food Science, 14(3), 211-217.

Benattia, F. K., Arrar, Z., \& Dergal, F. (2019). Chemical Composition and Nutritional Analysis of Seeds Cactus (Opuntia ficus-indica. L). Current Nutrition \& Food Science, 15(4), 394-400.

Bensadón, S., Hervert-Hernández, D., Sáyago-Ayerdi, S. G., \& Goñi, I. (2010). By-Products of Opuntia ficus-indica as a Source of Antioxidant Dietary Fiber. Plant Foods for Human Nutrition, 65(3), 210-216. doi:10.1007/s11130-010-0176-2

Berraaouan, A., Abderrahim, Z., Hassane, M., Abdelkhaleq, L., Mohammed, A., \& Mohamed, B. (2015). Evaluation of protective effect of cactus pear seed oil (Opuntia ficus-indica L. MILL.) against alloxan-induced diabetes in mice. Asian Pacific Journal of Tropical Medicine, 8(7), 532-537. doi:https://doi.org/10.1016/j.apjtm.2015.06.013

Berraaouan, A., Ziyyat, A., Mekhfi, H., Legssyer, A., Sindic, M., Aziz, M., \& Bnouham, M. (2014). Evaluation of antidiabetic properties of cactus pear seed oil in rats. Pharmaceutical Biology, 52(10), 1286-1290.

Betancourt, C., Cejudo-Bastante, M. J., Heredia, F. J., \& Hurtado, N. (2017). Pigment composition and antioxidant capacity of betacyanins and betaxanthins fractions of Opuntia dillenii (Ker Gawl) Haw cactus fruit. Food Research International, 101, 173179. doi:https://doi.org/10.1016/j.foodres.2017.09.007

Bieski, I. G. C., Leonti, M., Arnason, J. T., Ferrier, J., Rapinski, M., Violante, I. M. P., . . . Martins, D. T. d. O. (2015). Ethnobotanical study of medicinal plants by population of Valley of Juruena Region, Legal Amazon, Mato Grosso, Brazil. Journal of ethnopharmacology, 173, 383-423. doi:https://doi.org/10.1016/j.jep.2015.07.025

Bieski, I. G. C., Rios Santos, F., de Oliveira, R. M., Espinosa, M. M., Macedo, M., Albuquerque, U. P., \& de Oliveira Martins, D. T. (2012). Ethnopharmacology of medicinal plants of the pantanal region (Mato Grosso, Brazil). Evidence-Based Complementary and Alternative Medicine, 2012.

Blanco, L., \& Thiagarajan, T. (2017). Ethno-botanical study of medicinal plants used by the Yucatec maya in the northern district of Belize. International Journal of Herbal Medicine, 5, 33-42.

Blando, F., Russo, R., Negro, C., De Bellis, L., \& Frassinetti, S. (2019). Antimicrobial and Antibiofilm Activity against Staphylococcus aureus of Opuntia ficus-indica (L.) Mill. Cladode Polyphenolic Extracts. Antioxidants (Basel, Switzerland), 8(5), 117. doi:10.3390/antiox8050117

Budinsky, A., Wolfram, R., Oguogho, A., Efthimiou, Y., Stamatopoulos, Y., \& Sinzinger, H. (2001). Regular ingestion of Opuntia robusta lowers oxidation injury. Prostaglandins, Leukotrienes and Essential Fatty Acids (PLEFA), 65(1), 45-50. 
Bussmann, R. W., \& Glenn, A. (2010). Medicinal plants used in Northern Peru for reproductive problems and female health. Journal of Ethnobiology and Ethnomedicine, 6, 30-30. doi:10.1186/1746-4269-6-30

Butterweck, V., Semlin, L., Feistel, B., Pischel, I., Bauer, K., \& Verspohl, E. J. (2011). Comparative evaluation of two different Opuntia ficus-indica extracts for blood sugar lowering effects in rats. Phytotherapy Research, 25(3), 370-375. doi:10.1002/ptr.3271

Carag, H., \& Buot Jr, I. (2017). A checklist of the orders and families of medicinal plants in the Philippines. Sylvatrop, 27, 49-49.

Carrió, E., \& Vallès, J. (2012). Ethnobotany of medicinal plants used in Eastern Mallorca (Balearic Islands, Mediterranean Sea). Journal of Ethnopharmacology, 141(3), 10211040. doi:https://doi.org/10.1016/j.jep.2012.03.049

Cassels, B. K. (2019). Alkaloids of the Cactaceae-The Classics. Natural Product Communications, 14(1), 1934578X1901400123.

Castro, A., Lascurain-Rangel, M., Gómez-Díaz, J. A., \& Sosa, V. (2018). Mayan Homegardens in Decline: The Case of the Pitahaya (Hylocereus undatus), a Vine Cactus With Edible Fruit. Tropical Conservation Science, 11, 1940082918808730.

Cenobio-Galindo, A. d. J., Pimentel-González, D. J., Del Razo-Rodríguez, O. E., MedinaPérez, G., Carrillo-Inungaray, M. L., Reyes-Munguía, A., \& Campos-Montiel, R. G. (2019). Antioxidant and antibacterial activities of a starch film with bioextracts microencapsulated from cactus fruits (Opuntia oligacantha). Food Science and Biotechnology, 28(5), 1553-1561. doi:10.1007/s10068-019-00586-9

Chetry, L. B., Basar, K., Taye, K., Taka, T., Tsering, J., \& Wangpan, T. (2018). Medicinal Plants used against gastrointestinal disorders among the Adi Tribe of Eastern Himalaya. In: Nebio.

Chintu, R., Patel, U., Chauhan, V., Patel, H., Chirag, M., Modi, P., . . Shah, T. (2017). InVitro Antioxidant and Antidiabetic Activity of Hydro Alcoholic Extract of Opuntia elatior Fruit as Well as Quercetin. International Journal of Science, Environment and Technology, 6(2), 1028-1035.

Cicero, A. F. G., Derosa, G., \& Gaddi, A. (2004). What do herbalists suggest to diabetic patients in order to improve glycemic control? Evaluation of scientific evidence and potential risks. Acta Diabetologica, 41(3), 91-98. doi:10.1007/s00592-004-0150-2

Ciriminna, R., Delisi, R., Albanese, L., Meneguzzo, F., \& Pagliaro, M. (2017). Opuntia ficusindica seed oil: Biorefinery and bioeconomy aspects. European Journal of Lipid Science and Technology, 119(8), 1700013. doi:10.1002/ejlt.201700013

Clement, Y., Baksh-Comeau, Y., \& Seaforth, C. (2015). An ethnobotanical survey of medicinal plants in Trinidad. Journal of Ethnobiology and Ethnomedicine, 11(1), 67.

Cruz-Bravo, R. K., Guzmán-Maldonado, S. H., Araiza-Herrera, H. A., \& Zegbe, J. A. (2019). Storage alters physicochemical characteristics, bioactive compounds and antioxidant capacity of cactus pear fruit. Postharvest Biology and Technology, 150, 105-111. doi:https://doi.org/10.1016/j.postharvbio.2019.01.001

Cuénoud, P., Savolainen, V., Chatrou, L. W., Powell, M., Grayer, R. J., \& Chase, M. W. (2002). Molecular phylogenetics of Caryophyllales based on nuclear 18S rDNA and plastid rbcL, atpB, and matK DNA sequences. American Journal of Botany, 89(1), 132-144. doi:10.3732/ajb.89.1.132

Cushman, J. C. (2001). Crassulacean acid metabolism. A plastic photosynthetic adaptation to arid environments. Plant Physiology, 127(4), 1439-1448.

d'Avigdor, E., Wohlmuth, H., Asfaw, Z., \& Awas, T. (2014). The current status of knowledge of herbal medicine and medicinal plants in Fiche, Ethiopia. Journal of Ethnobiology and Ethnomedicine, 10, 38-38. doi:10.1186/1746-4269-10-38 
da Silva, N. F., Hanazaki, N., Albuquerque, U. P., Almeida Campos, J. L., Feitosa, I. S., \& Araújo, E. d. L. (2019). Local Knowledge and Conservation Priorities of Medicinal Plants near a Protected Area in Brazil. Evidence-Based Complementary and Alternative Medicine, 2019.

Das, P. K., Badore, N. S., Patel, P., \& Deshmukh, N. (2016). Ethnomedicinal wound healing plant in Khargone district of Madhya Pradesh: a survey over Nimari communities. Pharmaceutical and Biological Evaluations, 3(4), 388-399.

de Albuquerque, U. P. (2006). Re-examining hypotheses concerning the use and knowledge of medicinal plants: a study in the Caatinga vegetation of NE Brazil. Journal of Ethnobiology and Ethnomedicine, 2, 30-30. doi:10.1186/1746-4269-2-30

de la Cruz, M. G., Malpartida, S. B., Santiago, H. B., Jullian, V., \& Bourdy, G. (2014). Hot and cold: medicinal plant uses in Quechua speaking communities in the high Andes (Callejón de Huaylas, Ancash, Perú). Journal of Ethnopharmacology, 155(2), 10931117. doi:10.1016/j.jep.2014.06.042

de Lucena, C. M., de Lucena, R. F. P., Costa, G. M., Carvalho, T. K. N., da Silva Costa, G. G., da Nóbrega Alves, R. R., . . Quirino, Z. G. M. (2013). Use and knowledge of Cactaceae in Northeastern Brazil. Journal of Ethnobiology and Ethnomedicine, 9(1), 62.

del Socorro Santos-Díaz, M., \& Camarena-Rangel, N. G. (2019). Cacti for production of metabolites: current state and perspectives. Applied Microbiology and Biotechnology, 103(21-22), 8657-8667.

del Socorro Santos Díaz, M., Barba de la Rosa, A.-P., Héliès-Toussaint, C., Guéraud, F., \& Nègre-Salvayre, A. (2017). Opuntia spp.: Characterization and benefits in chronic diseases. Oxidative Medicine and Cellular Longevity, 2017.

Djerrou, Z., Maameri, Z., Halmi, S., Djaalab, H., Riachi, F., Benmaiza, L., \& Hamdipacha, Y. (2015). Hepatoprotective effect of Opuntia ficus-indica aqueous extract against carbon tetrachloride-induced toxicity in rats. OnLine Journal of Biological Sciences, $15(2), 36$.

Dok-Go, H., Lee, K. H., Kim, H. J., Lee, E. H., Lee, J., Song, Y. S., . . . Cho, J. (2003). Neuroprotective effects of antioxidative flavonoids, quercetin, $(+)$-dihydroquercetin and quercetin 3-methyl ether, isolated from Opuntia ficus-indica var. saboten. Brain Research, 965(1), 130-136. doi:https://doi.org/10.1016/S0006-8993(02)04150-1

Duque, J. G. (1980). The northeast and xerophilous crops. Collection Mossoroense, 193(3), 265.

El-Mostafa, K., El Kharrassi, Y., Badreddine, A., Andreoletti, P., Vamecq, J., El Kebbaj, M., . . Cherkaoui-Malki, M. (2014a). Nopal cactus (Opuntia ficus-indica) as a source of bioactive compounds for nutrition, health and disease. Molecules, 19(9), 1487914901.

El-Mostafa, K., El Kharrassi, Y., Badreddine, A., Andreoletti, P., Vamecq, J., El Kebbaj, M. H. S., . . . Cherkaoui-Malki, M. (2014b). Nopal cactus (Opuntia ficus-indica) as a source of bioactive compounds for nutrition, health and disease. Molecules (Basel, Switzerland), 19(9), 14879-14901. doi:10.3390/molecules190914879

Erbay, M., Anıl, S., \& Melikoğlu, G. (2016). Plants used in traditional treatment against anemia in Turkey. Marmara Pharmaceutical Journal, 20(2), 164-171.

Espinosa-Muñoz, V., RoldáN-cruz, C., HernáNdez-Fuentes, A., Quintero-Lira, A., Almaraz-Buendía, I., \& Campos-Montiel, R. (2017). Ultrasonic-assisted extraction of phenols, flavonoids, and biocompounds with inhibitory effect against Salmonella Typhimurium and Staphylococcus Aureus from Cactus pear. Journal of Food Process Engineering, 40(2), e12358. 
Estrada-Castillón, E., Villarreal-Quintanilla, J. Á., Rodríguez-Salinas, M. M., EncinasDomínguez, J. A., González-Rodríguez, H., Figueroa, G. R., \& Arévalo, J. R. (2018). Ethnobotanical Survey of Useful Species in Bustamante, Nuevo León, Mexico. Human Ecology, 46(1), 117-132. doi:10.1007/s10745-017-9962-x

Fabela-Illescas, H., Avila-Dominguez, R., Hernandez-Pacheco, A., Ariza, J. O., \& BetanzosCabrera, G. (2015). EFFECT OF A BEVERAGE MADE FROM CACTUS PEAR (NOPALEA COCHENILLIFERA (L) SALM-DYCK) IN A RURAL POPULATION OF HIDALGO, MEXICO; A PILOT CLINICAL TRIAL. Nutricion hospitalaria, $32(6), 2710-2714$.

Fathordoobady, F., Manap, M., Selamat, J., \& Singh, A. (2019). Development of supercritical fluid extraction for the recovery of betacyanins from red pitaya fruit (Hylocereus polyrhizus) peel: a source of natural red pigment with potential antioxidant properties. International Food Research Journal, 26(3), 1023-1034.

Franco-Molina, M., Gomez-Flores, R., Tamez-Guerra, P., Tamez-Guerra, R., Castillo-Leon, L., \& Rodríguez-Padilla, C. (2003). In vitro immunopotentiating properties and tumour cell toxicity induced by Lophophora williamsii (peyote) cactus methanolic extract. Phytother Res, 17(9), 1076-1081. doi:10.1002/ptr.1313

Fujihara, K., Takahashi, K., Koyama, K., \& Kinoshita, K. (2017). Triterpenoid saponins from Polaskia chichipe Backbg. and their inhibitory or promotional effects on the melanogenesis of B16 melanoma cells. Journal of Natural Medicines, 71(4), 606-616. doi:10.1007/s11418-017-1082-9

Galati, E. M., Mondello, M. R., Giuffrida, D., Dugo, G., Miceli, N., Pergolizzi, S., \& Taviano, M. F. (2003). Chemical Characterization and Biological Effects of Sicilian Opuntia ficus indica (L.) Mill. Fruit Juice: Antioxidant and Antiulcerogenic Activity. Journal of Agricultural and Food Chemistry, 51(17), 4903-4908. doi:10.1021/jf030123d

Galati, E. M., Monforte, M. T., Tripodo, M. M., d'Aquino, A., \& Mondello, M. R. (2001). Antiulcer activity of Opuntia ficus indica (L.) Mill. (Cactaceae): ultrastructural study. Journal of ethnopharmacology, 76(1), 1-9. doi:https://doi.org/10.1016/S03788741(01)00196-9

Gao, L., Wei, N., Yang, G., Zhang, Z., Liu, G., \& Cai, C. (2019). Ethnomedicine study on traditional medicinal plants in the Wuliang Mountains of Jingdong, Yunnan, China. Journal of ethnobiology and ethnomedicine, 15(1), 41-41. doi:10.1186/s13002-0190316-1

García-Cruz, L., Dueñas, M., Santos-Buelgas, C., Valle-Guadarrama, S., \& Salinas-Moreno, Y. (2017). Betalains and phenolic compounds profiling and antioxidant capacity of pitaya (Stenocereus spp.) fruit from two species (S. Pruinosus and S. stellatus). Food Chem, 234, 111-118. doi:10.1016/j.foodchem.2017.04.174

Garcia, J. A., Corrêa, R. C., Barros, L., Pereira, C., Abreu, R. M., Alves, M. J., . . Ferreira, I. C. (2019). Phytochemical profile and biological activities of'Ora-pro-nobis' leaves (Pereskia aculeata Miller), an underexploited superfood from the Brazilian Atlantic Forest. Food Chemistry, 294, 302-308.

Garcia, J. A. A., Corrêa, R. C. G., Barros, L., Pereira, C., Abreu, R. M. V., Alves, M. J., . . Ferreira, I. C. F. R. (2019). Phytochemical profile and biological activities of 'Orapro-nobis' leaves (Pereskia aculeata Miller), an underexploited superfood from the Brazilian Atlantic Forest. Food Chemistry, 294, 302-308. doi:https://doi.org/10.1016/j.foodchem.2019.05.074

Garoby-Salom, S., Guéraud, F., Camaré, C., de la Rosa, A.-P. B., Rossignol, M., Díaz, M. d. S. S., . . . Negre-Salvayre, A. (2016). Dietary cladode powder from wild type and domesticated Opuntia species reduces atherogenesis in apoE knock-out mice. Journal of Physiology and Biochemistry, 72(1), 59-70. doi:10.1007/s13105-015-0461-5 
Gentile, C., Tesoriere, L., Allegra, M., Livrea, M. A., \& D'Alessio, P. (2004). Antioxidant betalains from cactus pear (Opuntia ficus-indica) inhibit endothelial ICAM-1 expression. Ann N Y Acad Sci, 1028, 481-486. doi:10.1196/annals.1322.057

Gheribi, R., \& Khwaldia, K. (2019). Cactus Mucilage for Food Packaging Applications. Coatings, 9, 1-19. doi:doi:10.3390/coatings9100655

Godard, M. P., Ewing, B. A., Pischel, I., Ziegler, A., Benedek, B., \& Feistel, B. (2010). Acute blood glucose lowering effects and long-term safety of OpunDia supplementation in pre-diabetic males and females. Journal of ethnopharmacology, 130(3), 631-634. doi:10.1016/j.jep.2010.05.047

Gomez-Flores, R., Quintanilla-Licea, R., Hernández-Martínez, H. C., Samaniego-Escamilla, M., Tamez-Guerra, P., Monreal-Cuevas, E., . . . Rodriguez-Padilla, C. (2019). Survival of Lymphoma-Bearing Mice by Pachycereus marginatus Cactus Extracts and Elucidation of Bioactive Compounds. Natural Product Communications, 14(5), 1934578X19845814. doi:10.1177/1934578X19845814

González-Ponce, H. A., Martínez-Saldaña, M. C., Rincón-Sánchez, A. R., Sumaya-Martínez, M. T., Buist-Homan, M., Faber, K. N., . . . Jaramillo-Juárez, F. (2016). Hepatoprotective effect of Opuntia robusta and Opuntia streptacantha fruits against acetaminophen-induced acute liver damage. Nutrients, 8(10), 607.

Gouws, C. A., D’Cunha, N. M., Georgousopoulou, E. N., Mellor, D. D., \& Naumovski, N. (2019). The effect of different drying techniques on phytochemical content and in vitro antioxidant properties of Australian-grown prickly pears (Opuntia ficus indica). Journal of Food Processing and Preservation, 43(3), e13900. doi:10.1111/jfpp.13900

Grace, O. M. (2019). Succulent plant diversity as natural capital. PLANTS, PEOPLE, PLANET, 1(4), 336-345. doi:10.1002/ppp3.25

Gras, A., Garnatje, T., Bonet, M. À., Carrió, E., Mayans, M., Parada, M., . . Vallès, J. (2016). Beyond food and medicine, but necessary for life, too: other folk plant uses in several territories of Catalonia and the Balearic Islands. Journal of Ethnobiology and Ethnomedicine, 12(1), 23. doi:10.1186/s13002-016-0097-8

Grube, B., Chong, P. W., Lau, K. Z., \& Orzechowski, H. D. (2013). A natural fiber complex reduces body weight in the overweight and obese: a double-blind, randomized, placebo-controlled study. Obesity (Silver Spring), 21(1), 58-64. doi:10.1002/oby.20244

Güneş, S., Savran, A., Paksoy, M. Y., Koşar, M., \& Çakılcığlu, U. (2017). Ethnopharmacological survey of medicinal plants in Karaisalı and its surrounding (Adana-Turkey). Journal of Herbal Medicine, 8, 68-75. doi:https://doi.org/10.1016/j.hermed.2017.04.002

Gutiérrez-Grijalva, E. P., Picos-Salas, M. A., Leyva-López, N., Criollo-Mendoza, M. S., Vazquez-Olivo, G., \& Heredia, J. B. (2018). Flavonoids and phenolic acids from oregano: occurrence, biological activity and health benefits. Plants, 7(1), 2.

Hassanbaglou, B., Hamid, A. A., Roheeyati, A., Saleh, N. M., Abdulamir, A., Khatib, A., \& Sabu, M. (2012). Antioxidant activity of different extracts from leaves of Pereskia bleo (Cactaceae). Journal of Medicinal Plants Research, 6(15), 2932-2937.

Hernández, T., Canales, M., Avila, J. G., Duran, A., Caballero, J., Vivar, A. R. d., \& Lira, R. (2003). Ethnobotany and antibacterial activity of some plants used in traditional medicine of Zapotitlán de las Salinas, Puebla (México). Journal of ethnopharmacology, $\quad 88(2), \quad$ 181-188. doi:https://doi.org/10.1016/S0378$\underline{\text { 8741(03)00213-7 }}$

Hong, L., Guo, Z., Huang, K., Wei, S., Liu, B., Meng, S., \& Long, C. (2015). Ethnobotanical study on medicinal plants used by Maonan people in China. Journal of Ethnobiology and Ethnomedicine, 11(1), 32. doi:10.1186/s13002-015-0019-1 
Huang, X., Li, Q., Guo, L., \& Yan, Z. (2008). Protection of Cactus Polysaccharide against $\mathrm{H} 2 \mathrm{O} 2$-induced damage in the rat cerebral cortex and hippocampus* ${ }^{2}$ : Differences in time of administration. Neural Regeneration Research, 3(1), 14-18.

Huang, X., Li, Q., Li, H., \& Guo, L. (2009). Neuroprotective and antioxidative effect of cactus polysaccharides in vivo and in vitro. Cell Mol Neurobiol, 29(8), 1211-1221. doi:10.1007/s10571-009-9417-z

Hussain, E. A., Sadiq, Z., \& Zia-Ul-Haq, M. (2018). Betalains: Biomolecular Aspects: Springer.

Hwang, S. H., Kang, I. J., \& Lim, S. S. (2017). Antidiabetic Effect of Fresh Nopal (Opuntia ficus-indica) in Low-Dose Streptozotocin-Induced Diabetic Rats Fed a High-Fat Diet. Evid Based Complement Alternat Med, 2017, 4380721. doi:10.1155/2017/4380721

Issa, T. O., Mohamed, Y. S., Yagi, S., Ahmed, R. H., Najeeb, T. M., Makhawi, A. M., \& Khider, T. O. (2018). Ethnobotanical investigation on medicinal plants in Algoz area (South Kordofan), Sudan. Journal of ethnobiology and ethnomedicine, 14(1), 31-31. doi:10.1186/s13002-018-0230-y

Iyamah, P. C., \& Idu, M. (2015). Ethnomedicinal survey of plants used in the treatment of malaria in Southern Nigeria. $J$ Ethnopharmacol, 173, 287-302. doi:10.1016/j.jep.2015.07.008

Izuegbuna, O., Otunola, G., \& Bradley, G. (2019). Chemical composition, antioxidant, antiinflammatory, and cytotoxic activities of Opuntia stricta cladodes. PloS one, 14(1), e0209682. doi:10.1371/journal.pone.0209682

Jain, M., Shrivastava, P. N., \& Samar, R. (2018). Survey of Ethnobotanical Medicinal Plants Used by the People of District Guna, Madhya Pradesh, India. Int. J. Life. Sci. Scienti. Res. eISSN, 2455(1716), 1716.

Jang, H. T., Kumar, A. S., Ganesh, M., \& Peng, M. M. (2014). Phytochemical, anti-oxidant, antiviral and cytotoxic evaluation of Opuntia dillenii flowers. Bangladesh Journal of Pharmacology, 9(3), 351-355.

Jiménez-Aguilar, D. M., López-Martínez, J. M., Hernández-Brenes, C., Gutiérrez-Uribe, J. A., \& Welti-Chanes, J. (2015). Dietary fiber, phytochemical composition and antioxidant activity of Mexican commercial varieties of cactus pear. Journal of Food Composition and Analysis, 41, 66-73. doi:https://doi.org/10.1016/j.jfca.2015.01.017

Jiménez-Sierra, C. L., \& Eguiarte, L. E. (2010). Candy Barrel Cactus (Echinocactus platyacanthus Link \& Otto: A Traditional Plant Resource in Mexico Subject to Uncontrolled Extraction and Browsing. Economic Botany, 64(2), 99-108. doi:10.1007/s 12231-010-9119-y

Johnson, L., Strich, H., Taylor, A., Timmermann, B., Malone, D., Teufel-Shone, N., . . . Martinez, A. (2006). Use of herbal remedies by diabetic Hispanic women in the southwestern United States. Phytother Res, 20(4), 250-255. doi:10.1002/ptr.1820

Jost, X., Ansel, J. L., Lecellier, G., Raharivelomanana, P., \& Butaud, J. F. (2016). Ethnobotanical survey of cosmetic plants used in Marquesas Islands (French Polynesia). J Ethnobiol Ethnomed, 12(1), 55. doi:10.1186/s13002-016-0128-5

Kakuta, K., Baba, M., Ito, S., Kinoshita, K., Koyama, K., \& Takahashi, K. (2012). New triterpenoid saponins from cacti and anti-type I allergy activity of saponins from cactus. Bioorg Med Chem Lett, 22(14), 4793-4800. doi:10.1016/j.bmcl.2012.05.058

Kanungo, S., \& Satapathy, S. k. (2014). Evaluation of the Price Differences of Turmeric across India, a Statistical Analysis. IOSR Journal of Business and Management, 16(7), 4.

Katanić, J., Yousfi, F., Caruso, M. C., Matić, S., Monti, D. M., Loukili, E. H., . . Ramdani, M. (2019). Characterization of bioactivity and phytochemical composition with 
toxicity studies of different Opuntia dillenii extracts from Morocco. Food Bioscience, 30, 100410. doi:https://doi.org/10.1016/i.fbio.2019.04.011

Kaur, G., Thawkar, B., Dubey, S., \& Jadhav, P. (2018). Pharmacological potentials of betalains. Journal of Complementary and Integrative Medicine, 15(3).

Keller, J., Camaré, C., Bernis, C., Astello-García, M., de la Rosa, A.-P. B., Rossignol, M., . . . Guéraud, F. (2015). Antiatherogenic and antitumoral properties of Opuntia cladodes: inhibition of low density lipoprotein oxidation by vascular cells, and protection against the cytotoxicity of lipid oxidation product 4-hydroxynonenal in a colorectal cancer cellular model. Journal of Physiology and Biochemistry, 71(3), 577-587. doi:10.1007/s 13105-015-0408-x

Khan, M. P., \& Ahmad, M. (2015). Traditional preference of Wild Edible Fruits (WEFs) for digestive disorders (DDs) among the indigenous communities of Swat ValleyPakistan. J Ethnopharmacol, 174, 339-354. doi:10.1016/j.jep.2015.08.024

Kim, D. H., Enkhtaivan, G., Kumar Saini, R., Keum, Y.-S., Kang, K. W., \& Sivanesan, I. (2019). Production of bioactive compounds in cladode culture of Turbinicarpus valdezianus (H. Moeller) Glass \& R. C. Foster. Industrial Crops and Products, 138, 111491. doi:https://doi.org/10.1016/j.indcrop.2019.111491

Kim, J. H., Park, S. M., Ha, H. J., Moon, C. J., Shin, T. K., Kim, J. M., . . Wie, M. B. (2006). Opuntia ficus-indica attenuates neuronal injury in in vitro and in vivo models of cerebral ischemia. $J$ Ethnopharmacol, 104(1-2), 257-262. doi:10.1016/j.jep.2005.09.017

Kıvrak, Ş., Kıvrak, İ., \& Karababa, E. (2018). Analytical evaluation of phenolic compounds and minerals of Opuntia robusta J.C. Wendl. and Opuntia ficus-barbarica A. Berger. International Journal of Food Properties, 21(1), 229-241. doi:10.1080/10942912.2018.1451342

Koche, D. (2008). Ethnobotanical and Ethnomedicinal Survey of Nagzira Wildlife Sanctuary, District Gondia (MS) India-Part I. Ethnobotanical leaflets, 2008(1), 8.

Kose, L. S., Moteetee, A., \& Van Vuuren, S. (2015). Ethnobotanical survey of medicinal plants used in the Maseru district of Lesotho. Journal of ethnopharmacology, 170, 184-200.

Koubaa, M., Mhemdi, H., Barba, F. J., Angelotti, A., Bouaziz, F., Chaabouni, S. E., \& Vorobiev, E. (2017). Seed oil extraction from red prickly pear using hexane and supercritical $\mathrm{CO}(2)$ : assessment of phenolic compound composition, antioxidant and antibacterial activities. J Sci Food Agric, 97(2), 613-620. doi:10.1002/jsfa.7774

Kwon, Y., Liao, Y., Koo, B., Bae, H., Zhang, J., Han, E. H., . . Ryu, J. H. (2018). Ethanolic Extract of Opuntia ficus-indica var. saboten Ameliorates Cognitive Dysfunction Induced by Cholinergic Blockade in Mice. J Med Food, 21(10), 971-978. doi:10.1089/jmf.2017.4131

Lans, C. (2007). Comparison of plants used for skin and stomach problems in Trinidad and Tobago with Asian ethnomedicine. Journal of ethnobiology and ethnomedicine, 3, 3-3. doi:10.1186/1746-4269-3-3

Lans, C. (2007). Ethnomedicines used in Trinidad and Tobago for reproductive problems. $J$ Ethnobiol Ethnomed, 3, 13. doi:10.1186/1746-4269-3-13

Lans, C. A. (2006). Ethnomedicines used in Trinidad and Tobago for urinary problems and diabetes mellitus. J Ethnobiol Ethnomed, 2, 45. doi:10.1186/1746-4269-2-45

Lara Reimers, E. A., Lara Reimers, D. J., Chaloupkova, P., Zepeda del Valle, J. M., Milella, L., \& Russo, D. (2019). An Ethnobotanical Survey of Medicinal Plants Used in Papantla, Veracruz, Mexico. Plants, 8(8), 246.

Lema-Rumińska, J., \& Kulus, D. (2014). Micropropagation of Cacti-a Review. Haseltonia, 2014(19), 46-63, 18. 
Li, X., Li, M., Ji, N., Jin, P., Zhang, J., Zheng, Y., . . . Li, F. (2019). Cold plasma treatment induces phenolic accumulation and enhances antioxidant activity in fresh-cut pitaya $\begin{array}{lllll}\text { (Hylocereus undatus) fruit. } & \text { LWT, }\end{array}$ doi:https://doi.org/10.1016/j.lwt.2019.108447

Lima-Nascimento, A. M. d., Bento-Silva, J. S., Lucena, C. M. d., \& Lucena, R. F. P. d. (2019). Ethnobotany of native cacti in the northeast region of Brazil: can traditional use influence availability? Acta Botanica Brasilica, 33(2), 350-359.

Linarès, E., Thimonier, C., \& Degre, M. (2007). The effect of neopuntia ${ }^{\circledR}$ on blood lipid parameters-Risk factors for the metabolic syndrome (Syndrome $\chi$ ). Advances in Therapy, 24(5), 1115-1125. doi:10.1007/BF02877717

Loi, M. C., Maxia, L., \& Maxia, A. (2005). Ethnobotanical Comparison Between the Villages of Escolca and Lotzorai (Sardinia, Italy). Journal of Herbs, Spices \& Medicinal Plants, 11(3), 67-84. doi:10.1300/J044v11n03_07

Loizzo, M. R., Bruno, M., Balzano, M., Giardinieri, A., Pacetti, D., Frega, N. G., . . Tundis, R. (2019). Comparative Chemical Composition and Bioactivity of Opuntia ficusindica Sanguigna and Surfarina Seed Oils Obtained by Traditional and UltrasoundAssisted Extraction Procedures. European Journal of Lipid Science and Technology, 121(1), 1800283. doi:10.1002/ejlt.201800283

López-Romero, P., Pichardo-Ontiveros, E., Avila-Nava, A., Vázquez-Manjarrez, N., Tovar, A. R., Pedraza-Chaverri, J., \& Torres, N. (2014). The effect of nopal (Opuntia ficus indica) on postprandial blood glucose, incretins, and antioxidant activity in Mexican patients with type 2 diabetes after consumption of two different composition breakfasts. J Acad Nutr Diet, 114(11), 1811-1818. doi:10.1016/j.jand.2014.06.352

Loro, J. F., del Rio, I., \& Pérez-Santana, L. (1999). Preliminary studies of analgesic and antiinflammatory properties of Opuntia dillenii aqueous extract. Journal of ethnopharmacology, 67(2), 213-218. doi:https://doi.org/10.1016/S03788741(99)00027-6

Maataoui, S. B., Maataoui, R. B., Almesrarm, B., \& Hilali, S. (2018). Antiulcer activity of Prickly Pear (Opuntia ficus indica) cladodes extracts. International Journal of Advanced Research, 6(11), 498-506.

Madrigal-Santillán, E., García-Melo, F., Morales-González, J. A., Vázquez-Alvarado, P., Muñoz-Juárez, S., Zuñiga-Pérez, C., . . . Hernández-Ceruelos, A. (2013). Antioxidant and anticlastogenic capacity of prickly pear juice. Nutrients, 5(10), 4145-4158. doi:10.3390/nu5104145

Maema, L. P., Potgieter, M., \& Mahlo, S. M. (2016). INVASIVE ALIEN PLANT SPECIES USED FOR THE TREATMENT OF VARIOUS DISEASES IN LIMPOPO PROVINCE, SOUTH AFRICA. Afr J Tradit Complement Altern Med, 13(4), 223-231. doi:10.21010/ajtcam.v13i4.29

Malek, S. N., Shin, S. K., Wahab, N. A., \& Yaacob, H. (2009). Cytotoxic components of Pereskia bleo (Kunth) DC. (Cactaceae) leaves. Molecules, 14(5), 1713-1724. doi:10.3390/molecules14051713

Manach, C., Scalbert, A., Morand, C., Rémésy, C., \& Jiménez, L. (2004). Polyphenols: food sources and bioavailability. The American Journal of Clinical Nutrition, 79(5), 727747. doi:10.1093/ajcn/79.5.727

Maroyi, A. (2017). Diversity of use and local knowledge of wild and cultivated plants in the Eastern Cape province, South Africa. Journal of Ethnobiology and Ethnomedicine, 13(1), 43. doi:10.1186/s13002-017-0173-8

Martínez, G. J., \& Barboza, G. E. (2010). Natural pharmacopoeia used in traditional Toba medicine for the treatment of parasitosis and skin disorders (Central Chaco, Argentina). J Ethnopharmacol, 132(1), 86-100. doi:10.1016/j.jep.2010.07.049 
Mat Darus, N., \& Mohamad, J. (2017). Antidiabetic Activity of Pereskia Bleo Aqueous Extracts in Alloxan Induced Diabetic Rats. J Pharm Res 1(7), J Pharm Res

Mautone, M., De Martino, L., \& De Feo, V. (2019). Ethnobotanical research in Cava de' Tirreni area, Southern Italy. Journal of Ethnobiology and Ethnomedicine, 15(1), 50. doi:10.1186/s 13002-019-0330-3

Medina-Pérez, G., Zaldívar-Ortega, A. K., Cenobio-Galindo, A. d. J., Afanador-Barajas, L. N., Vieyra-Alberto, R., Estefes-Duarte, J. A., \& Campos-Montiel, R. G. (2019). Antidiabetic Activity of Cactus Acid Fruit Extracts: Simulated Intestinal Conditions of the Inhibitory Effects on $\alpha$-amylase and $\alpha$-glucosidase. Applied Sciences, 9(19), 4066.

Melgar, B., Dias, M. I., Ciric, A., Sokovic, M., Garcia-Castello, E. M., Rodriguez-Lopez, A. D., . . . Ferreira, I. (2017). By-product recovery of Opuntia spp. peels: Betalainic and phenolic profiles and bioactive properties. Industrial Crops and Products, 107, 353359. doi:https://doi.org/10.1016/j.indcrop.2017.06.011

Mena, P., Tassotti, M., Andreu, L., Nuncio-Jáuregui, N., Legua, P., Del Rio, D., \& Hernández, F. (2018). Phytochemical characterization of different prickly pear (Opuntia ficus-indica (L.) Mill.) cultivars and botanical parts: UHPLC-ESI-MSn metabolomics profiles and their chemometric analysis. Food Research International, 108, 301-308. doi:https://doi.org/10.1016/j.foodres.2018.03.062

Messaoudi, M. I., Filali, H., Tazi, A., Hakkou, F., Moussi, M., Filali, H., . . Hakkou, F. (2015). Ethnobotanical survey of healing medicinal plants traditionally used in the main Moroccan cities. Journal of Pharmacognosy and Phytotherapy, 7(8), 164-182.

Molares, S., \& Ladio, A. (2014). Medicinal plants in the cultural landscape of a MapucheTehuelche community in arid Argentine Patagonia: an eco-sensorial approach. Journal of ethnobiology and ethnomedicine, 10(1), 61.

Mondal, A., Gandhi, A., Fimognari, C., Atanasov, A. G., \& Bishayee, A. (2019). Alkaloids for cancer prevention and therapy: Current progress and future perspectives. European journal of pharmacology, 858, 172472.

Mongalo, N. I., \& Makhafola, T. J. (2018). Ethnobotanical knowledge of the lay people of Blouberg area (Pedi tribe), Limpopo Province, South Africa. Journal of ethnobiology and ethnomedicine, 14(1), 46.

Moussa-Ayoub, T. E., El-Hady, E.-S. A. A., Omran, H. T., El-Samahy, S. K., Kroh, L. W., \& Rohn, S. (2014). Influence of cultivar and origin on the flavonol profile of fruits and cladodes from cactus Opuntia ficus-indica. Food Research International, 64, 864-872.

Moussa-Ayoub, T. E., Youssef, K., El-Samahy, S. K., Kroh, L. W., \& Rohn, S. (2015). Flavonol profile of cactus fruits (Opuntia ficus-indica) enriched cereal-based extrudates: Authenticity and impact of extrusion. Food Research International, 78, 442-447.

Msaddak, L., Abdelhedi, O., Kridene, A., Rateb, M., Belbahri, L., Ammar, E., . . Zouari, N. (2017). Opuntia ficus-indica cladodes as a functional ingredient: bioactive compounds profile and their effect on antioxidant quality of bread. Lipids in health and disease, $16(1), 32$.

Ncibi, S., Othman, M. B., Akacha, A., Krifi, M. N., \& Zourgui, L. (2008). Opuntia ficus indica extract protects against chlorpyrifos-induced damage on mice liver. Food and Chemical Toxicology, 46(2), 797-802.

Noël, P. H., Pugh, J. A., Larme, A. C., \& Marsh, G. (1997). The use of traditional plant medicines for non-insulin dependent diabetes mellitus in south Texas. Phytotherapy Research: An International Journal Devoted to Medical and Scientific Research on Plants and Plant Products, 11(7), 512-517. 
Novoa, A., Le Roux, J. J., Robertson, M. P., Wilson, J. R., \& Richardson, D. M. (2015). Introduced and invasive cactus species: a global review. AoB Plants, 7.

Nunes, A. T., Lucena, R. F. P., dos Santos, M. V. F., \& Albuquerque, U. P. (2015). Local knowledge about fodder plants in the semi-arid region of Northeastern Brazil. Journal of ethnobiology and ethnomedicine, 11(1), 12.

Ochoa, M., \& Barbera, G. (2017). History and economic and agro-ecological importance. Inglese P, Mondragon C, Nefzaoui A, et al., Crop Ecology, Cultivation and Uses of Cactus Pear, Rome: The Food and Agriculture Organization of the United Nations and the International Center for Agricultural Research in the Dry Areas, 1-11.

Okazaki, S., Kinoshita, K., Ito, S., Koyama, K., Yuasa, H., \& Takahashi, K. (2011). Triterpenoid saponins from Echinopsis macrogona (Cactaceae). Phytochemistry, 72(1), 136-146.

Okazaki, S., Kinoshita, K., Koyama, K., Takahashi, K., \& Yuasa, H. (2007). New triterpene saponins from Stenocereus eruca (Cactaceae). Journal of Natural Medicines, 61(1), 24-29.

Olowa, L., \& Demayo, C. G. (2015). Ethnobotanical uses of medicinal plants among the Muslim Maranaos in Iligan City, Mindanao, Philippines. Advances in Environmental Biology, 9(27), 204-215.

Omosun, G., Okoro, I., Ekundayo, E., Ojimelukwe, P., \& Ibe, O. (2013). Ethnobotanical study of medicinal plants useful for malaria therapy in eight local government areas of Abia State, Southeast Nigeria. Advancement in Medicinal Plant Research, 1(2), 39-44.

Onakpoya, I. J., O'Sullivan, J., \& Heneghan, C. J. (2015). The effect of cactus pear (Opuntia ficus-indica) on body weight and cardiovascular risk factors: a systematic review and meta-analysis of randomized clinical trials. Nutrition, 31(5), 640-646.

Ortega-Baes, P., \& Godínez-Alvarez, H. (2006). Global diversity and conservation priorities in the Cactaceae. Biodiversity \& Conservation, 15(3), 817-827.

Ortega-Baes, P., Sühring, S., Sajama, J., Sotola, E., Alonso-Pedano, M., Bravo, S., \& Godínez-Alvarez, H. (2010). Diversity and conservation in the cactus family. In Desert plants (pp. 157-173): Springer.

Ortega-Ortega, M. d. 1. A., Cruz-Cansino, N. d. S., Alanís-García, E., Delgado-Olivares, L., Ariza-Ortega, J. A., Ramírez-Moreno, E., \& Manríquez-Torres, J. d. J. (2017). Optimization of ultrasound extraction of cactus pear (Opuntia ficus indica) seed oil based on antioxidant activity and evaluation of its antimicrobial activity. Journal of Food Quality, 2017.

Osuna-Martínez, U., Reyes-Esparza, J., \& Rodríguez-Fragoso, L. (2014). Cactus (Opuntia ficus-indica): A Review on its Antioxidants Properties and Potential Pharmacological Use in Chronic Diseases. Nat Prod Chem Res 2: 153. doi: 10.4172/23296836.1000153 Page 2 of 8 and protein $(0.5-1 \%)$; other compounds are only partly known and have not been quantitatively determined [9]. The sugar moiety includes mucilaginous components containing polymers, such as chains of (1-4)-linked $\beta$-Dgalacturonic acid and R (1-2)-linked L-rhamnose residues [10, 11]. The physiological role of the plant mucilage is to regulate the cellular water content during prolonged drought and to regulate the calcium fluxes of the plant $[12,13]$. Opuntia ficus-indica.

Ouerghemmi, I., Harbeoui, H., Aidi Wannes, W., Bettaieb Rebey, I., Hammami, M., Marzouk, B., \& Saidani Tounsi, M. (2017). Phytochemical composition and antioxidant activity of Tunisian cactus pear (Opuntia ficus indica L.) flower. Journal of Food Biochemistry, 41(5), e12390.

Palheta, I. C., Tavares-Martins, A. C. C., Lucas, F. C. A., \& Jardim, M. A. G. (2017). Ethnobotanical study of medicinal plants in urban home gardens in the city of 
Abaetetuba, Pará state, Brazil. Boletín Latinoamericano y del Caribe de Plantas Medicinales y Aromáticas, 16(3), 206-262.

Pandey, A., \& Mavinkurve, R. G. (2014). Ethno-Botanical usage of plants by the Chakma community of Tripura, Northeast India. Bull. Env. Pharmacol. Life Sci, 3, 11-14.

Pandita, D., Pandita, A., \& Pandita, S. (2013). Herbaceous medicinal \& therapeutic plants of district samba of jammu province, jammu \& kashmir (India). Int J Indig Med Plants, 46, 2051-4263.

Panghal, M., Arya, V., Yadav, S., Kumar, S., \& Yadav, J. P. (2010). Indigenous knowledge of medicinal plants used by Saperas community of Khetawas, Jhajjar District, Haryana, India. Journal of Ethnobiology and Ethnomedicine, 6(1), 4.

Park, E.-H., Kahng, J.-H., Lee, S. H., \& Shin, K.-H. (2001). An anti-inflammatory principle from cactus. Fitoterapia, 72(3), 288-290.

Pedrosa, T. M. (2000). Arte popular de Alagoas. Maceió: Grafitex, 206-208.

Pérez-Molphe-Balch, E., Santos-Díaz, M. d. S., Ramírez-Malagón, R., \& Ochoa-Alejo, N. (2015). Tissue culture of ornamental cacti. Scientia Agricola, 72(6), 540-561.

Philip, K., Malek, S. N., Sani, W., Shin, S. K., Kumar, S., Lai, H. S., . . . Rahman, S. N. (2009). Antimicrobial activity of some medicinal plants from Malaysia. American Journal of Applied Sciences, 6(8), 1613.

Pinedo-Espinoza, J. M., Aguirre-Mancilla, C. L., Jiménez-Alvarado, R., de la FUENTE, G. I., RAMÍREZ-PIMENTEL, J. G., HERNÁNDEZ-FUENTES, A. D., \& Raya-Pérez, J. C. (2017). Bioactive compounds and antioxidant activity evolution during the ripening process of 12 Opuntia spp. fruit accessions. Emirates Journal of Food and Agriculture, 138-148.

Pinto, N. d. C. C., Santos, R., Machado, D., Florêncio, J., Fagundes, E., Antinarelli, L., ... . Scio, E. (2012). Cytotoxic and antioxidant activity of Pereskia aculeata Miller. Pharmacologyonline, 3, 63-69.

Pinto, N. d. C. C., \& Scio, E. (2014). The biological activities and chemical composition of Pereskia species (Cactaceae) - A review. Plant foods for human nutrition, 69(3), 189195.

Pinto Nde, C., Machado, D. C., da Silva, J. M., Conegundes, J. L., Gualberto, A. C., Gameiro, J., . . . Scio, E. (2015). Pereskia aculeata Miller leaves present in vivo topical antiinflammatory activity in models of acute and chronic dermatitis. J Ethnopharmacol, 173, 330-337. doi:10.1016/j.jep.2015.07.032

Pratap, G. P., \& Prasad, G. (2009). Ethno medical studies in Kailasagirikona forest range of Chittoor district, Andhra Pradesh. Ancient science of life, 29(2), 40.

Quiroga, R., Meneses, L., \& Bussmann, R. W. (2012). Medicinal ethnobotany in Huacareta (Chuquisaca, Bolivia). Journal of ethnobiology and ethnomedicine, 8(1), 29.

Qureshi, J., Afzal, S., \& Kin, L. (2019). Anti-inflammatory activity of topical polyherbal formulation containing Pereskia bleo and Camellia sinensis leaves extract. Frontiers in Pharmacology. Conference Abstract: International Conference on Drug Discovery and Translational Medicine 2018 (ICDDTM '18) "Seizing Opportunities and Addressing Challenges of Precision Medicine". doi:10.3389/conf.fphar.2018.63.00120

Rahimi, P., Abedimanesh, S., Mesbah-Namin, S. A., \& Ostadrahimi, A. (2019). Betalains, the nature-inspired pigments, in health and diseases. Critical reviews in food science and nutrition, 59(18), 2949-2978.

Rahmatullah, M., Ayman, U., Akter, F., Sarker, M., Sifa, R., Sarker, B., . . Chowdhury, S. A. (2013). Medicinal formulations of a Kanda tribal healer-a tribe on the verge of disappearance in Bangladesh. African Journal of Traditional, Complementary and Alternative Medicines, 10(2), 213-222. 
Rahmatullah, M., Mollik, A. H., Ali, M., Abbas, F. B., Jahan, R., Chowdhury, M. H., . . . Chowdhury, A. (2011). An ethnomedicinal survey of Vitbilia village in Sujanagar sub-district of Pabna district, Bangladesh. Am Eurasian J Agric Environ Sci, 10(1), 106-111.

Raj, A. J., Biswakarma, S., Pala, N. A., Shukla, G., Kumar, M., Chakravarty, S., \& Bussmann, R. W. (2018). Indigenous uses of ethnomedicinal plants among forest-dependent communities of Northern Bengal, India. Journal of ethnobiology and ethnomedicine, 14(1), 8.

Ramírez-Moreno, E., Cariño-Cortés, R., Cruz-Cansino, N. d. S., Delgado-Olivares, L., ArizaOrtega, J. A., Montañez-Izquierdo, V. Y., . . . Filardo-Kerstupp, T. (2017). Antioxidant and antimicrobial properties of cactus pear (Opuntia) seed oils. Journal of Food Quality, 2017.

Randriamiharisoa, M. N., Kuhlman, A. R., Jeannoda, V., Rabarison, H., Rakotoarivelo, N., Randrianarivony, T., . . . Bussmann, R. W. (2015). Medicinal plants sold in the markets of Antananarivo, Madagascar. Journal of Ethnobiology and Ethnomedicine, $11(1), 60$.

Ranjarisoa, L. N., Razanamihaja, N., \& Rafatro, H. (2016). Use of plants in oral health care by the population of Mahajanga, Madagascar. Journal of ethnopharmacology, 193, 179-194.

Rebman, J. P., \& Pinkava, D. J. (2001). Opuntia Cacti of North America: An Overview. The Florida Entomologist, 84(4), 474-483. doi:10.2307/3496374

Robles-Martínez, M., Barba-de la Rosa, A. P., Guéraud, F., Negre-Salvayre, A., Rossignol, M., \& del Socorro Santos-Díaz, M. (2016). Establishment of callus and cell suspensions of wild and domesticated Opuntia Species: Study on their potential as a source of metabolite production. Plant Cell, Tissue and Organ Culture (PCTOC), 124(1), 181-189.

Rocchetti, G., Pellizzoni, M., Montesano, D., \& Lucini, L. (2018). Italian Opuntia ficusindica cladodes as rich source of bioactive compounds with health-promoting properties. Foods, 7(2), 24.

Roman-Ramos, R., Flores-Saenz, J., \& Alarcon-Aguilar, F. (1995). Anti-hyperglycemic effect of some edible plants. Journal of ethnopharmacology, 48(1), 25-32.

Ruiz del Castillo, M. L., Santa-María, G., Herraiz, M., \& Blanch, G. P. (2003). A comparative study of the ability of different techniques to extract menthol from Mentha piperita. Journal of chromatographic science, 41(7), 385-389.

Salazar, J. R., \& Céspedes, C. L. (2013). Phytoecdysteroids and related sterols isolated from Mexican cacti: their potential use as natural insecticides. Natural antioxidants and biocides from wild medicinal plants. CABI, Oxfordshire, 167-175.

Salhi, N., Bouyahya, A., Fettach, S., Zellou, A., \& Cherrah, Y. (2019). Ethnopharmacological study of medicinal plants used in the treatment of skin burns in occidental Morocco (area of Rabat). South African journal of botany, 121, 128-142.

Samoisy, A. K., \& Mahomoodally, M. F. (2015). Ethnopharmacological analysis of medicinal plants used against non-communicable diseases in Rodrigues Island, Indian Ocean. Journal of ethnopharmacology, 173, 20-38.

Schäferhoff, B., Müller, K. F., \& Borsch, T. (2010). $<\mathrm{i}>$ Caryophyllales $</ \mathrm{i}>$ phylogenetics: disentangling $<\mathrm{i}>$ Phytolaccaceae $</ \mathrm{i}>$ and $<\mathrm{i}>$ Molluginaceae $</ \mathrm{i}>$ and description of $<\mathrm{i}>$ Microteaceae $</ \mathrm{i}>$ as a new isolated family. Willdenowia, 39(2), 209-228, 220.

Semenya, S., \& Potgieter, M. (2014). Medicinal plants cultivated in Bapedi traditional healers homegardens, Limpopo province, South Africa. African Journal of Traditional, Complementary and Alternative Medicines, 11(5), 126-132. 
Semenya, S., Potgieter, M., \& Erasmus, L. (2012). Ethnobotanical survey of medicinal plants used by Bapedi healers to treat diabetes mellitus in the Limpopo Province, South Africa. Journal of ethnopharmacology, 141(1), 440-445.

Semenya, S. S., \& Maroyi, A. (2018). Plants used by Bapedi traditional healers to treat asthma and related symptoms in Limpopo province, South Africa. Evidence-Based Complementary and Alternative Medicine, 2018.

Sen, U. K., \& Bhakat, R. K. (2018). Ethnobotanical study on sand-dune based medicinal plants and traditional therapies in coastal Purba Medinipur district, West Bengal, India. European Journal of Medicinal Plants, 1-19.

Sewani-Rusike, C. R., \& Mammen, M. (2014). Medicinal plants used as home remedies: a family survey by first year medical students. African Journal of Traditional, Complementary and Alternative Medicines, 11(5), 67-72.

Shackleton, R. T., Witt, A. B., Piroris, F. M., \& van Wilgen, B. W. (2017). Distribution and socio-ecological impacts of the invasive alien cactus Opuntia stricta in eastern Africa. Biological Invasions, 19(8), 2427-2441.

Shaheen, H., Qaseem, M. F., Amjad, M. S., \& Bruschi, P. (2017). Exploration of ethnomedicinal knowledge among rural communities of Pearl Valley; Rawalakot, District Poonch Azad Jammu and Kashmir. PloS one, 12(9), e0183956.

Sharif, K., Rahman, M., Azmir, J., Shamsudin, S. H., Uddin, M., Fahim, T., \& Zaidul, I. (2015). Ethanol modified supercritical carbon dioxide extraction of antioxidant rich extract from Pereskia bleo. Journal of Industrial and Engineering Chemistry, 21, 1314-1322.

Shetty, A. A., Rana, M., \& Preetham, S. (2012). Cactus: a medicinal food. Journal of food science and technology, 49(5), 530-536.

Siew, Y. Y., Zareisedehizadeh, S., Seetoh, W. G., Neo, S. Y., Tan, C. H., \& Koh, H. L. (2014). Ethnobotanical survey of usage of fresh medicinal plants in Singapore. $J$ Ethnopharmacol, 155(3), 1450-1466. doi:10.1016/j.jep.2014.07.024

Silva, D. O., Seifert, M., Schiedeck, G., Dode, J. S., \& Nora, L. (2018). Pereskia aculeata cultivada no sul do Brasil. Horticultura Brasileira, 36(3), 325-329.

Silva Fdos, S., Albuquerque, U. P., Costa Júnior, L. M., Lima Ada, S., do Nascimento, A. L., \& Monteiro, J. M. (2014). An ethnopharmacological assessment of the use of plants against parasitic diseases in humans and animals. J Ethnopharmacol, 155(2), 13321341. doi:10.1016/j.jep.2014.07.036

Sim, K., Sri Nurestri, A., \& Norhanom, A. (2010). Phenolic content and antioxidant activity of crude and fractionated extracts of Pereskia bleo (Kunth) DC.(Cactaceae). African Journal of Pharmacy and Pharmacology, 4(5), 193-201.

Smeriglio, A., Bonasera, S., Germanò, M. P., D'Angelo, V., Barreca, D., Denaro, M., . . . Trombetta, D. (2019). Opuntia ficus-indica (L.) Mill. fruit as source of betalains with antioxidant, cytoprotective, and anti-angiogenic properties. Phytotherapy Research, 33(5), 1526-1537. doi:10.1002/ptr.6345

Souza, L. F., Caputo, L., Inchausti De Barros, I. B., Fratianni, F., Nazzaro, F., \& De Feo, V. (2016). Pereskia aculeata Muller (Cactaceae) Leaves: Chemical Composition and Biological Activities. International journal of molecular sciences, 17(9), 1478. doi:10.3390/ijms17091478

Souza, L. F., De Barros, I. B., Mancini, E., De Martino, L., Scandolera, E., \& De Feo, V. (2014). Chemical composition and biological activities of the essential oils from two Pereskia species grown in Brazil. Nat Prod Commun, 9(12), 1805-1808.

Suárez, M. E. (2019). Medicines in the forest: Ethnobotany of wild medicinal plants in the pharmacopeia of the Wichí people of Salta province (Argentina). J Ethnopharmacol, 231, 525-544. doi:10.1016/j.jep.2018.10.026 
Tagarelli, G., Tagarelli, A., \& Piro, A. (2010). Folk medicine used to heal malaria in Calabria (southern Italy). J Ethnobiol Ethnomed, 6, 27. doi:10.1186/1746-4269-6-27

Tamba, A., Servent, A., Mertz, C., Cissé, M., \& Dornier, M. (2019). Coupling of pressuredriven membrane technologies for concentrating, purifying and fractionizing betacyanins in cactus pear (Opuntia dillenii Haw.) juice. Innovative food science \& emerging technologies, 52, 244-255. doi:https://doi.org/10.1016/j.ifset.2018.12.008

Tantengco, O. A. G., Condes, M. L. C., Estadilla, H. H. T., \& Ragragio, E. M. (2018). Ethnobotanical survey of medicinal plants used by ayta communities in Dinalupihan, Bataan, Philippines. Pharmacognosy Journal, 10(5).

Tariq, A., Mussarat, S., Adnan, M., Abd_Allah, E., Hashem, A., Alqarawi, A. A., \& Ullah, R. (2015). Ethnomedicinal evaluation of medicinal plants used against gastrointestinal complaints. BioMed Research International, 2015.

Teklay, A., Abera, B., \& Giday, M. (2013). An ethnobotanical study of medicinal plants used in Kilte Awulaelo District, Tigray Region of Ethiopia. J Ethnobiol Ethnomed, 9(1), 65. doi:10.1186/1746-4269-9-65

Tesoriere, L., Butera, D., Pintaudi, A. M., Allegra, M., \& Livrea, M. A. (2004). Supplementation with cactus pear (Opuntia ficus-indica) fruit decreases oxidative stress in healthy humans: a comparative study with vitamin C. The American Journal of Clinical Nutrition, 80(2), 391-395.

The Angiosperm Phylogeny Group., Chase, M. W., Christenhusz, M. J. M., Fay, M. F., Byng, J. W., Judd, W. S., . . . Stevens, P. F. (2016). An update of the Angiosperm Phylogeny Group classification for the orders and families of flowering plants: APG IV. Botanical Journal of the Linnean Society, 181(1), 1-20. doi:10.1111/boj.12385

Tshikalange, T. E., Mophuting, B. C., Mahore, J., Winterboer, S., \& Lall, N. (2016). AN ETHNOBOTANICAL STUDY OF MEDICINAL PLANTS USED IN VILLAGES UNDER JONGILANGA TRIBAL COUNCIL, MPUMALANGA, SOUTH AFRICA. Afr J Tradit Complement Altern Med, 13(6), 83-89. doi:10.21010/ajtcam.v13i6.13

Tuttolomondo, T., Licata, M., Leto, C., Gargano, M. L., Venturella, G., \& La Bella, S. (2014). Plant genetic resources and traditional knowledge on medicinal use of wild shrub and herbaceous plant species in the Etna Regional Park (Eastern Sicily, Italy). $J$ Ethnopharmacol, 155(2), 1362-1381. doi:10.1016/j.jep.2014.07.043

Tuttolomondo, T., Licata, M., Leto, C., Savo, V., Bonsangue, G., Letizia Gargano, M., .. . La Bella, S. (2014). Ethnobotanical investigation on wild medicinal plants in the Monti Sicani Regional Park (Sicily, Italy). Journal of ethnopharmacology, 153(3), 568-586. doi:https://doi.org/10.1016/j.jep.2014.02.032

Upasani, M. S., Upasani, S. V., Beldar, V. G., Beldar, C. G., \& Gujarathi, P. P. (2018). Infrequent use of medicinal plants from India in snakebite treatment. Integr Med Res, 7(1), 9-26. doi:10.1016/j.imr.2017.10.003

Vajha, M., Amrutha, V., \& Audipudi, M. (2010). Evaluation of immunostimulating activities of Caralluma spp. Int J Pharmacogn Phytochem Res, 2, 1-4.

Van Proeyen, K., Ramaekers, M., Pischel, I., \& Hespel, P. (2012). Opuntia ficus-indica ingestion stimulates peripheral disposal of oral glucose before and after exercise in healthy men. International journal of sport nutrition and exercise metabolism, 22(4), 284-291.

Vedavathy, S., Sudhakar, A., \& Mrdula, V. (1997). Tribal medicinal plants of chittoor. Ancient science of life, 16(4), 307-331.

Veeramani Kandan, P., Dhineshkumar, E., Karthikeyan, R., Anbuselvan, C., Maqbool, I., Kanimozhi, G., . . . Rajendra Prasad, N. (2019). Isolation and characterization of opuntiol from Opuntia Ficus indica (L. Mill) and its antiproliferative effect in KB oral carcinoma cells. Nat Prod Res, 1-5. doi:10.1080/14786419.2019.1690484 
Ventura-Aguilar, R. I., Bosquez-Molina, E., Bautista-Baños, S., \& Rivera-Cabrera, F. (2017). Cactus stem (Opuntia ficus-indica Mill): anatomy, physiology and chemical composition with emphasis on its biofunctional properties. J Sci Food Agric, 97(15), 5065-5073. doi:10.1002/jsfa.8493

Ventura-Aguilar, R. I., Bosquez-Molina, E., Bautista-Baños, S., \& Rivera-Cabrera, F. (2017). Cactus stem (Opuntia ficus-indica Mill): anatomy, physiology and chemical composition with emphasis on its biofunctional properties. Journal of the Science of Food and Agriculture, 97(15), 5065-5073.

Vieira, C. R., da Silva, B. P., do Carmo, M. A. V., Azevedo, L., Nogueira, D. A., Duarte Martino, H. S., \& Silva, R. R. (2019). Effect of Pereskia aculeata Mill. in vitro and in overweight humans: A randomized controlled trial. Journal of Food Biochemistry, 43(7), e12903. doi:10.1111/jfbc. 12903

Vinagre, C., Vinagre, S., \& Carrilho, E. (2019). The use of medicinal plants by the population from the Protected Landscape of "Serra de Montejunto", Portugal. Journal of Ethnobiology and Ethnomedicine, 15(1), 30. doi:10.1186/s13002-019-0309-0

Wahab, S., Abdul, A., Mohan, S., Al-Zubain, A., Elhassan, M., \& Ibrahim, M. (2009). Biological activities of pereskia bleo extracts. Int J Pharmacol, 5(1), 71-75.

Wen, L., Zhang, Z., Sun, D.-W., Sivagnanam, S. P., \& Tiwari, B. K. (2019). Combination of emerging technologies for the extraction of bioactive compounds. Critical Reviews in Food Science and Nutrition, 1-16. doi:10.1080/10408398.2019.1602823

Wolfram, R. M., Kritz, H., Efthimiou, Y., Stomatopoulos, J., \& Sinzinger, H. (2002). Effect of prickly pear (Opuntia robusta) on glucose- and lipid-metabolism in non-diabetics with hyperlipidemia--a pilot study. Wiener klinische Wochenschrift, 114(19-20), 840846.

Woo, C. S. J., Lau, J. S. H., \& El-Nezami, H. (2012). Chapter 10 - Herbal Medicine: Toxicity and Recent Trends in Assessing Their Potential Toxic Effects. In L.-F. Shyur \& A. S. Y. Lau (Eds.), Advances in Botanical Research (Vol. 62, pp. 365-384): Academic Press.

Wu, Y., Xu, J., He, Y., Shi, M., Han, X., Li, W., . . Wen, X. (2019). Metabolic Profiling of Pitaya (Hylocereus polyrhizus) during Fruit Development and Maturation. Molecules (Basel, Switzerland), 24(6), 1114. doi:10.3390/molecules24061114

Wybraniec, S., \& Nowak-Wydra, B. (2007). Mammillarinin: a new malonylated betacyanin from fruits of Mammillaria. $J$ Agric Food Chem, 55(20), 8138-8143. doi:10.1021/jf071095s

Yang, Y., Moore, M. J., Brockington, S. F., Soltis, D. E., Wong, G. K.-S., Carpenter, E. J., . . . Smith, S. A. (2015). Dissecting Molecular Evolution in the Highly Diverse Plant Clade Caryophyllales Using Transcriptome Sequencing. Molecular biology and evolution, 32(8), 2001-2014. doi:10.1093/molbev/msv081

Zareisedehizadeh, S., Tan, C. H., \& Koh, H. L. (2014). A Review of Botanical Characteristics, Traditional Usage, Chemical Components, Pharmacological Activities, and Safety of Pereskia bleo (Kunth) DC. Evid Based Complement Alternat Med, 2014, 326107. doi:10.1155/2014/326107

Zorgui, L., Ayed-Boussema, I., Ayed, Y., Bacha, H., \& Hassen, W. (2009). The antigenotoxic activities of cactus (Opuntia ficus-indica) cladodes against the mycotoxin zearalenone in Balb/c mice: Prevention of micronuclei, chromosome aberrations and DNA fragmentation. Food and Chemical Toxicology, 47(3), 662-667. doi:https://doi.org/10.1016/j.fct.2008.12.031 
1 Table 1. Traditional use of cactus as herbal medicines.

\begin{tabular}{|c|c|c|c|c|}
\hline Name & Common Name & $\begin{array}{c}\text { Parts of } \\
\text { the cactus } \\
\text { used } *\end{array}$ & Therapeutic uses & References \\
\hline $\begin{array}{l}\text { Cephalocereus senilis (Haw.) } \\
\text { Pfeiff }\end{array}$ & & $\mathrm{Pu}$ & $\begin{array}{l}\text { External wound: spread raw pulp on the affected } \\
\text { area (Mexico) }\end{array}$ & $\begin{array}{l}\text { (Estrada-Castillón et al., } \\
\text { 2018) }\end{array}$ \\
\hline \multirow{3}{*}{ Cereus jamacaru DC. } & \multirow{3}{*}{$\begin{array}{l}\text { Queen of the } \\
\text { night cactus }\end{array}$} & $\mathrm{Ma}$ & $\begin{array}{l}\text { Cough, column, wound, furuncle, urinary infection, } \\
\text { inflammation, kidney inflammation, rheumatism: } \\
\text { drink syrup (Brazil) }\end{array}$ & (de Lucena et al., 2013) \\
\hline & & St & $\begin{array}{l}\text { Urinary tract infection and kidney problems: drink } \\
\text { decoction (Brazil); Erysipelas: macerate in a bath } \\
\text { and apply as a plaster (Brazil); Sore throat, chest } \\
\text { pain, lung problems, flu, quebranto: drink syrup } \\
\text { (Brazil); Kidney stone (Brazil); Kidney disease: } \\
\text { scrape off the bark in the water and drink (Brazil) }\end{array}$ & $\begin{array}{l}\text { (da Silva et al., 2019; de } \\
\text { Albuquerque, 2006; } \\
\text { Palheta, Tavares- } \\
\text { Martins, Lucas, \& } \\
\text { Jardim, 2017) }\end{array}$ \\
\hline & & Ro & Kidney stone (Brazil) & (da Silva et al., 2019) \\
\hline $\begin{array}{l}\text { Cereus hildmannianus } \\
\text { K.Schum. }\end{array}$ & Hedge cactus & $\mathrm{Mu}$ & Heat-stroke: direct application (Bolivia) & $\begin{array}{l}\text { (Quiroga, Meneses, \& } \\
\text { Bussmann, 2012) }\end{array}$ \\
\hline
\end{tabular}




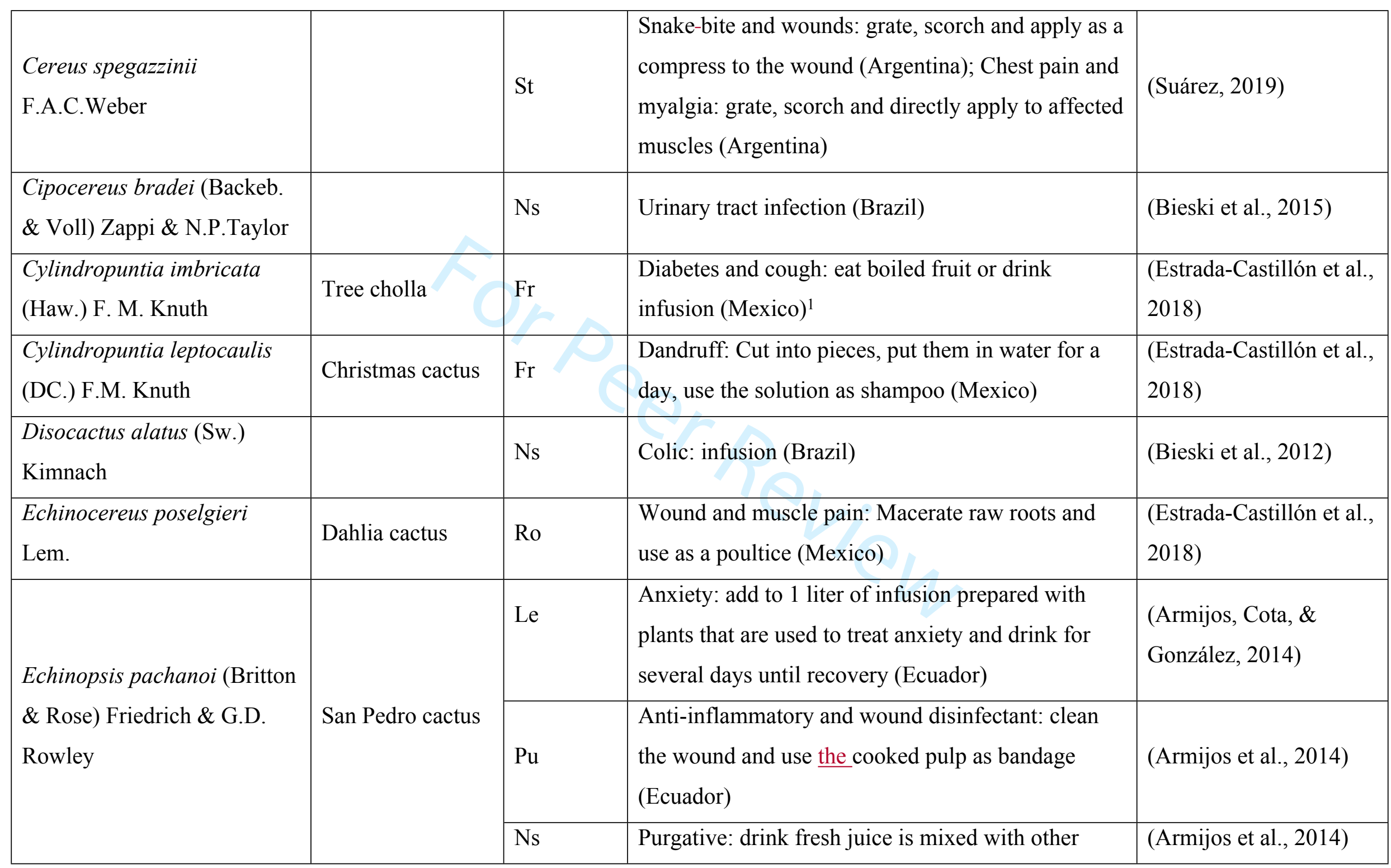




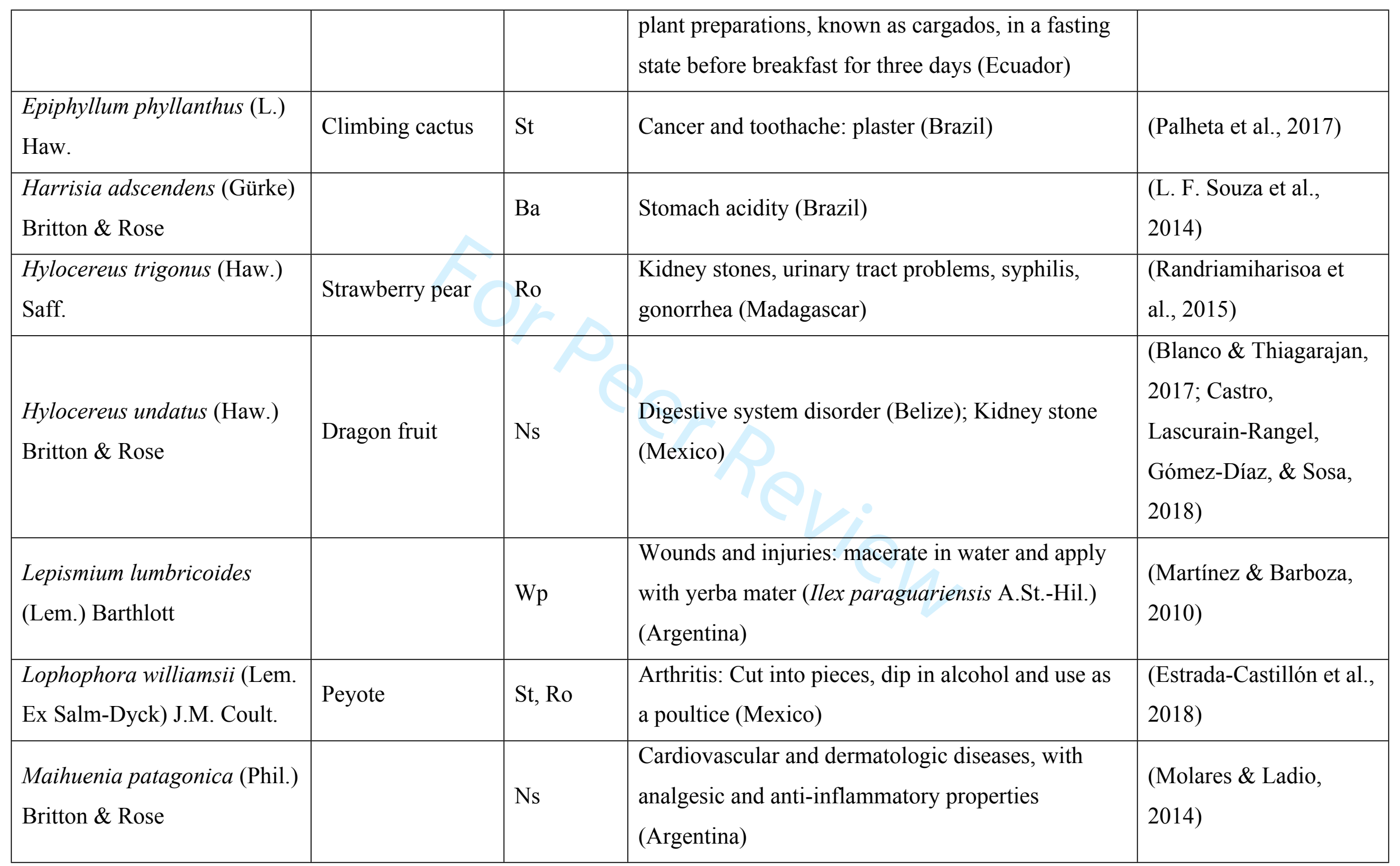




\begin{tabular}{|c|c|c|c|c|}
\hline \multirow{2}{*}{$\begin{array}{l}\text { Marginatocereus marginatus } \\
\text { (DC.) Backeb. }\end{array}$} & \multirow{2}{*}{$\begin{array}{l}\text { Mexican } \\
\text { fencepost cactus }\end{array}$} & Ap & Diarrhea: boil for ten minutes and drink (Mexico) & (Hernández et al., 2003) \\
\hline & & Ns & Diabetes (USA) & (Johnson et al., 2006) \\
\hline $\begin{array}{l}\text { Melocactus bahiensis } \\
\text { (Britton \& Rose) Luetzelb. }\end{array}$ & & $\mathrm{Ma}$ & $\begin{array}{l}\text { Amoeba, catarrh, whooping cough, cough: drink } \\
\text { syrup from marrow (Brazil) }\end{array}$ & (de Lucena et al., 2013) \\
\hline \multirow[b]{2}{*}{$\begin{array}{l}\text { Melocactus zehntneri } \\
\text { (Britton \& Rose) Luetzelb. }\end{array}$} & \multirow[b]{2}{*}{ Melon cactus } & Le & Drink decoction for worm infection (Brazil) & (Silva Fdos et al., 2014) \\
\hline & & Ns & $\begin{array}{l}\text { Contraceptive: One teaspoon plant powder mixed } \\
\text { with sugar taken on an empty stomach from the first } \\
\text { day of the menstrual cycle up to } 20 \text { days (India) }\end{array}$ & $\begin{array}{l}\text { (Balakrishnan, Prema, } \\
\text { Ravindran, \& Robinson, } \\
\text { 2009) }\end{array}$ \\
\hline \multirow{2}{*}{$\begin{array}{l}\text { Nopalea cochenillifera }(\mathrm{L} .) \\
\text { Salm-Dyck }\end{array}$} & \multirow{2}{*}{$\begin{array}{l}\text { Cochineal nopal } \\
\text { cactus }\end{array}$} & Le & $\begin{array}{l}\text { Drink a hot or cold infusion of grated leaves for } \\
\text { cooling and cleanser (Trinidad and Tobago); } \\
\text { Sprain: pound, put in the affected area, and wrapped } \\
\text { with a piece of cloth (Philippines); Earache, } \\
\text { toothache, and rheumatism (Philippines) }\end{array}$ & $\begin{array}{l}\text { (Carag \& Buot Jr, 2017; } \\
\text { Clement, Baksh- } \\
\text { Comeau, \& Seaforth, } \\
\text { 2015; Olowa \& } \\
\text { Demayo, 2015) }\end{array}$ \\
\hline & & Ns & Infection and circulatory system disorder (Belize) & $\begin{array}{l}\text { (Blanco \& Thiagarajan, } \\
\text { 2017; Sewani-Rusike \& } \\
\text { Mammen, 2014) }\end{array}$ \\
\hline Opuntia aurantiaca Lindl. & Tiger pear & Le & $\begin{array}{l}\text { Wound and sore healing: burn to ashes and mix } \\
\text { with petroleum jelly for topical application (South }\end{array}$ & \\
\hline
\end{tabular}




\begin{tabular}{|c|c|c|c|c|}
\hline & & & $\begin{array}{l}\text { Africa); Diabetes and hypertension: drink infusion } \\
\text { (South Africa) }\end{array}$ & \\
\hline Opuntia cochenillifera DC. & $\begin{array}{l}\text { Cochineal nopal } \\
\text { cactus }\end{array}$ & St & $\begin{array}{l}\text { Wound and abscess: remove the thorn and skin, } \\
\text { crush and bind onto the wound or abscess } \\
\text { (Mauritius) }\end{array}$ & $\begin{array}{l}\text { (Samoisy \& } \\
\text { Mahomoodally, 2015) }\end{array}$ \\
\hline \multirow[t]{4}{*}{$\begin{array}{l}\text { Opuntia dillenii (Ker-Gawl) } \\
\text { Haw. }\end{array}$} & \multirow[t]{4}{*}{ Erect prickly pear } & Fr & $\begin{array}{l}\text { Constipation: Drink boiled ripe fruit in water with } \\
\text { sugar (Pakistan); Anti-inflammatory and } \\
\text { expectorant (Pakistan) } \\
\text { Asthma and whooping cough: ripe fruit used as a } \\
\text { demulcent and expectorant while juice from the } \\
\text { fruit is used in to treat asthma and whooping cough } \\
\text { (India); Gonorrhea: fruit is used (India); Snake-bite } \\
\text { and dog bite: fruit paste is applied on the wound } \\
\text { (India); Snake-bite (India) }\end{array}$ & $\begin{array}{l}\text { (Alagesaboopathi, 2009; } \\
\text { Barkatullah et al., 2015; } \\
\text { Koche, 2008; Tariq et } \\
\text { al., 2015; Upasani, } \\
\text { Upasani, Beldar, Beldar, } \\
\text { \& Gujarathi, 2018) }\end{array}$ \\
\hline & & Le & $\begin{array}{l}\text { Guinea worms: A poultice made from the leaves is } \\
\text { used to extract guinea worms (India); Wounds: } \\
\text { apply a poultice of the crushed stem (India) }\end{array}$ & $\begin{array}{l}\text { (Jain, Shrivastava, \& } \\
\text { Samar, 2018; Koche, } \\
\text { 2008) }\end{array}$ \\
\hline & & $\mathrm{Sa}$ & Applied to the paralyzed area (Bangladesh) & $\begin{array}{l}\text { (Rahmatullah et al., } \\
\text { 2011) }\end{array}$ \\
\hline & & St & $\begin{array}{l}\text { Hypertension (Nigeria); Antiphlogosis and } \\
\text { unknown swollen part of the body (China); Dysuria }\end{array}$ & $\begin{array}{l}\text { (Ajayi, Moody, \& } \\
\text { Anthony, 2019; Gao et }\end{array}$ \\
\hline
\end{tabular}




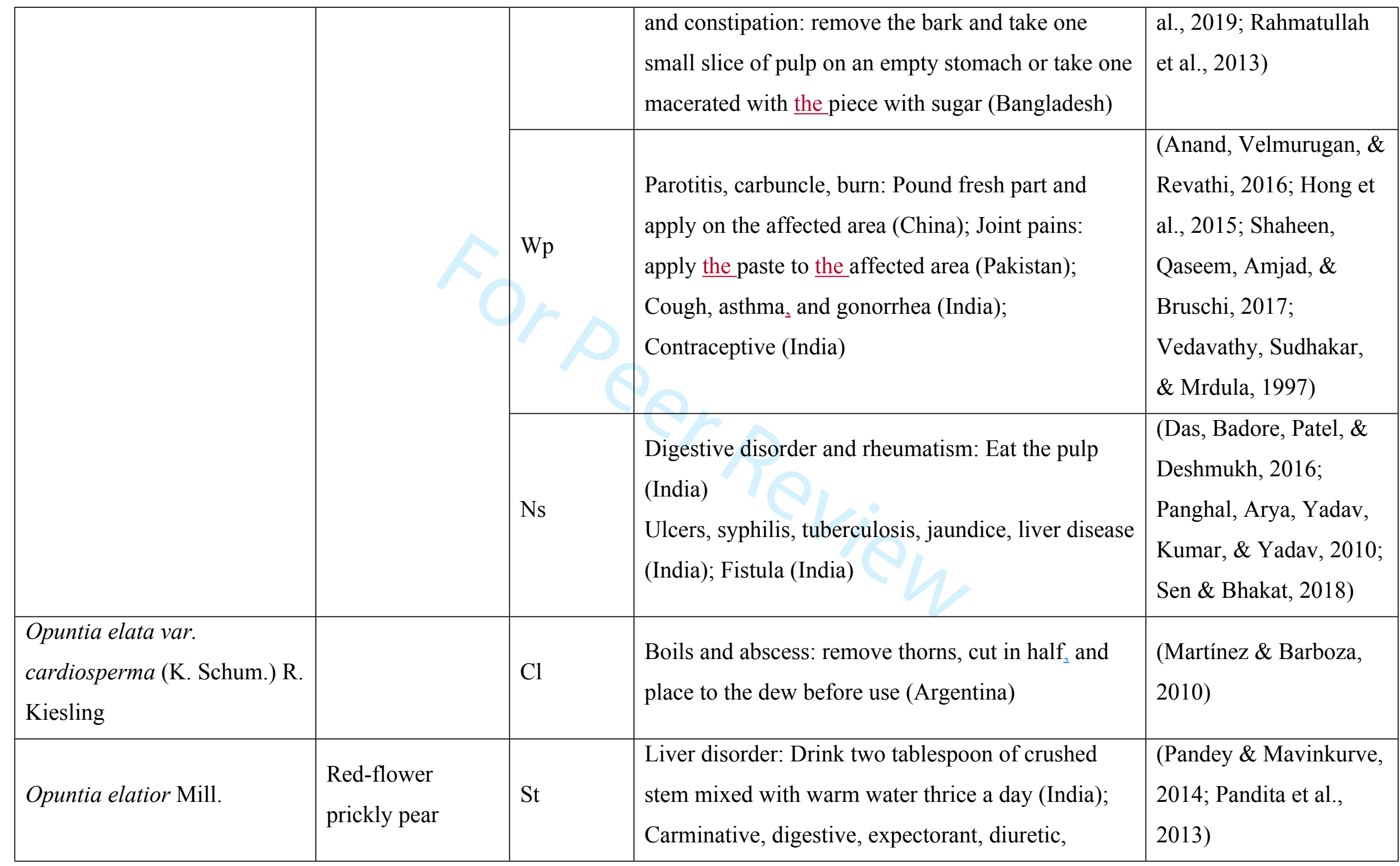




\begin{tabular}{|c|c|c|c|c|}
\hline & & & $\begin{array}{l}\text { purgative; bronchitis, leukoderma, splenomegaly, } \\
\text { dysuria, vesicular calculi, ophthalmic disorders, } \\
\text { whooping cough, asthma }{ }_{2} \text { and gonorrhea (India) }\end{array}$ & \\
\hline \multirow{4}{*}{$\begin{array}{l}\text { Opuntia ficus-indica }(\mathrm{L} .) \\
\text { Miller }\end{array}$} & \multirow{4}{*}{$\begin{array}{l}\text { Barbary fig; } \\
\text { Common prickly } \\
\text { pear }\end{array}$} & $\mathrm{Cl}$ & $\begin{array}{l}\text { Contusions, digestive diseases, hematomas, kidney } \\
\text { diseases, }_{2} \text { and wounds: decoction, direct application } \\
\text { and infusion (Italy) }\end{array}$ & $\begin{array}{l}\text { (Teresa Tuttolomondo } \\
\text { et al., 2014) }\end{array}$ \\
\hline & & Ex & $\begin{array}{l}\text { Heatstroke, sunburn, yellow fever, renal problems, } \\
\text { gastritis: use cataplasm, bath }{ }_{2} \text { or infusion (Bolivia) }\end{array}$ & (Quiroga et al., 2012) \\
\hline & & $\mathrm{Fl}$ & $\begin{array}{l}\text { Contusions, digestive diseases, hematomas, kidney } \\
\text { diseases, and wounds: decoction, direct application }_{2} \\
\text { and infusion (Italy); Digestive disorder: drink } \\
\text { infusion or decoction (Italy) }\end{array}$ & $\begin{array}{l}\text { (T. Tuttolomondo et al., } \\
\text { 2014; Teresa } \\
\text { Tuttolomondo et al., } \\
\text { 2014) }\end{array}$ \\
\hline & & $\mathrm{Fr}$ & $\begin{array}{l}\text { Diuretic and treatment for digestive disorders } \\
\text { (Italy); Wounds (Mexico); Stretch marks and } \\
\text { wrinkles: apply once a day for one week } \\
\text { (Morocco); Joint dislocation and tonsillitis: apply } \\
\text { aerial parts boiled, heated }{ }_{2} \text { or made into a poultice } \\
\text { with salt once a day for one to two weeks (Turkey); } \\
\text { Antispasmodic, diuretic, emollient, astringent, }\end{array}$ & $\begin{array}{l}\text { (Ahmet Sargin, 2015; } \\
\text { de-De la Cruz et al., } \\
\text { 2014; Erbay et al., } \\
\text { 2016; Khan \& Ahmad, } \\
\text { 2015; Maroyi, 2017; } \\
\text { Messaoudi et al., 2015; } \\
\text { Pandita et al., 2013; T. }\end{array}$ \\
\hline
\end{tabular}




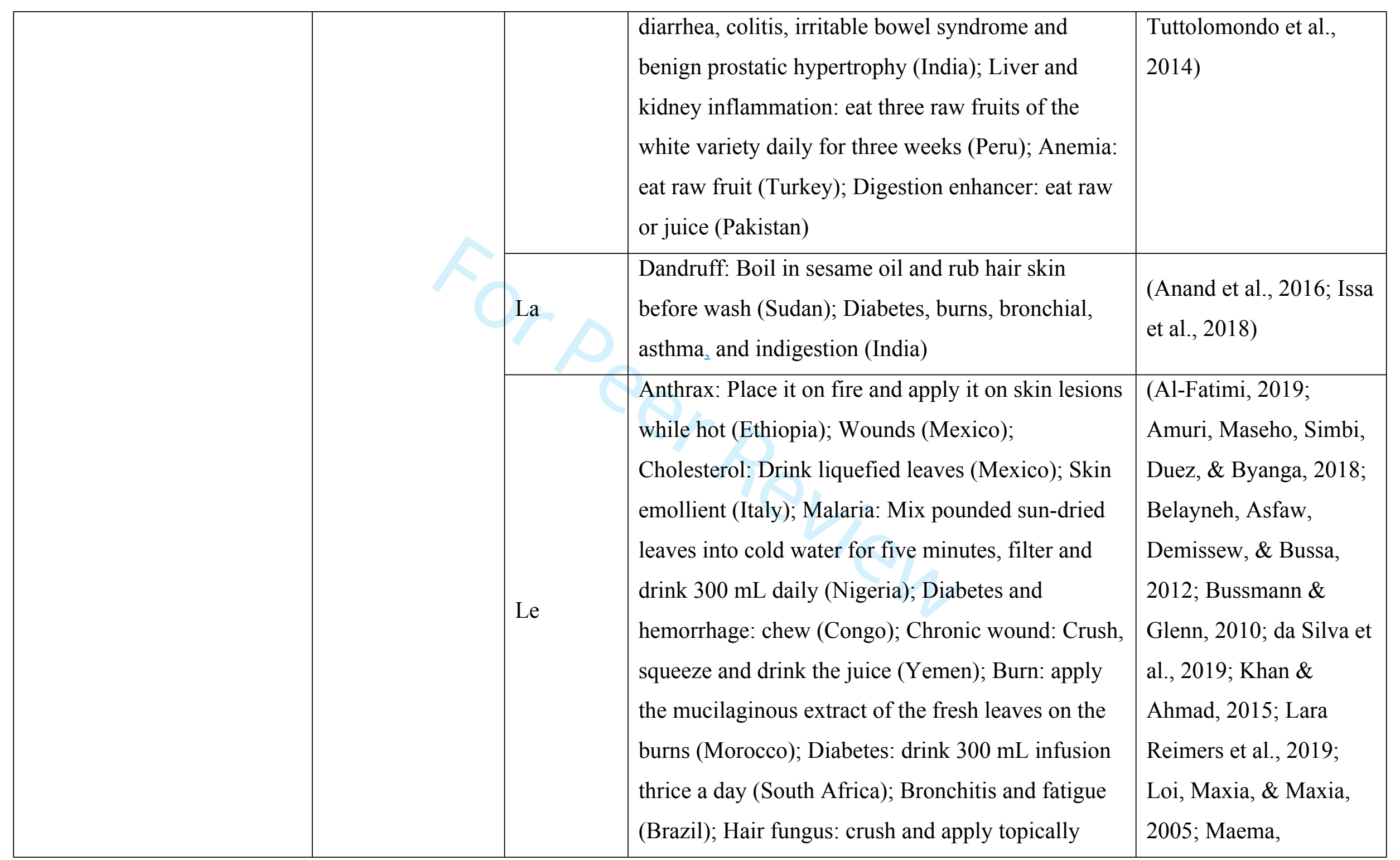




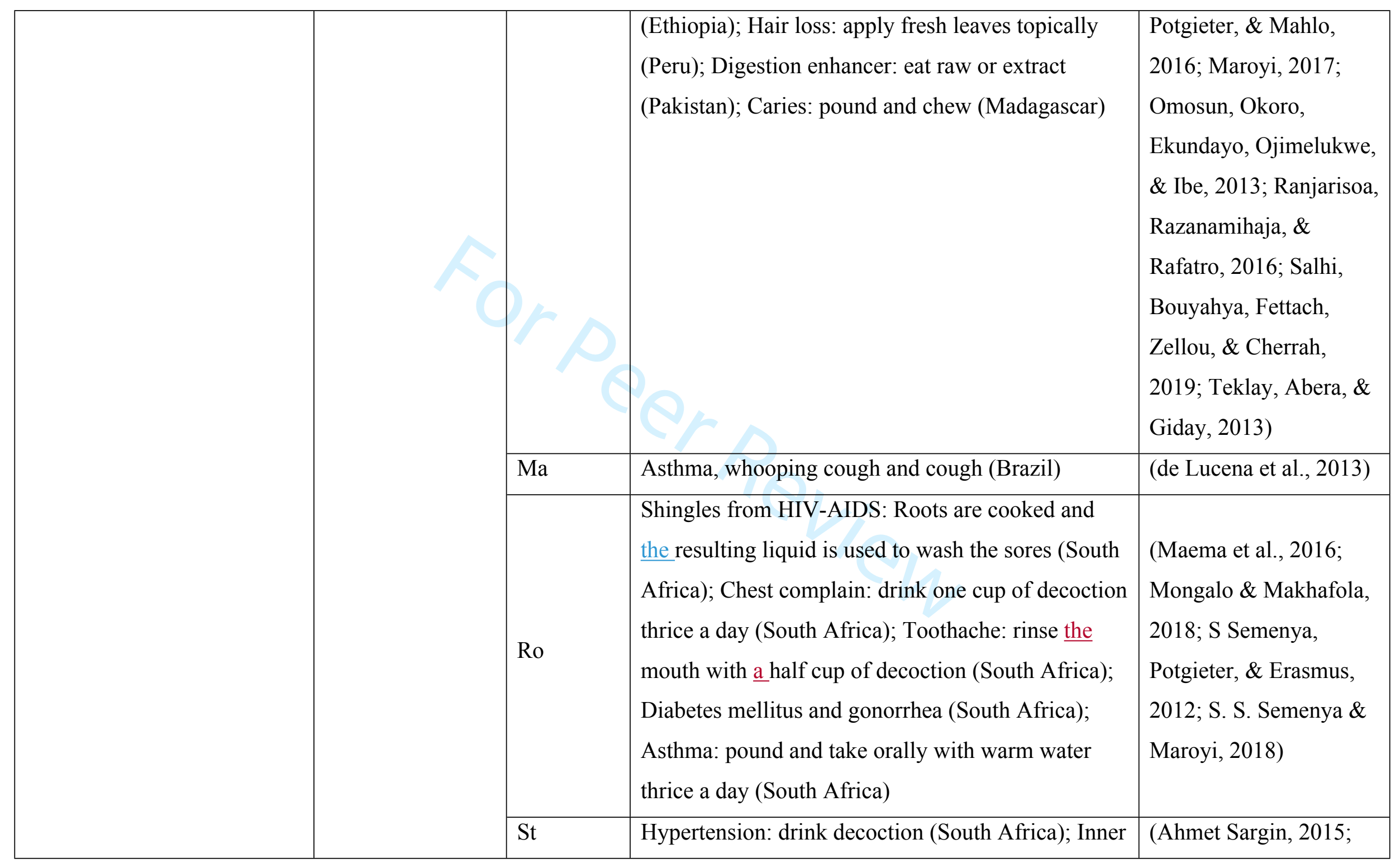




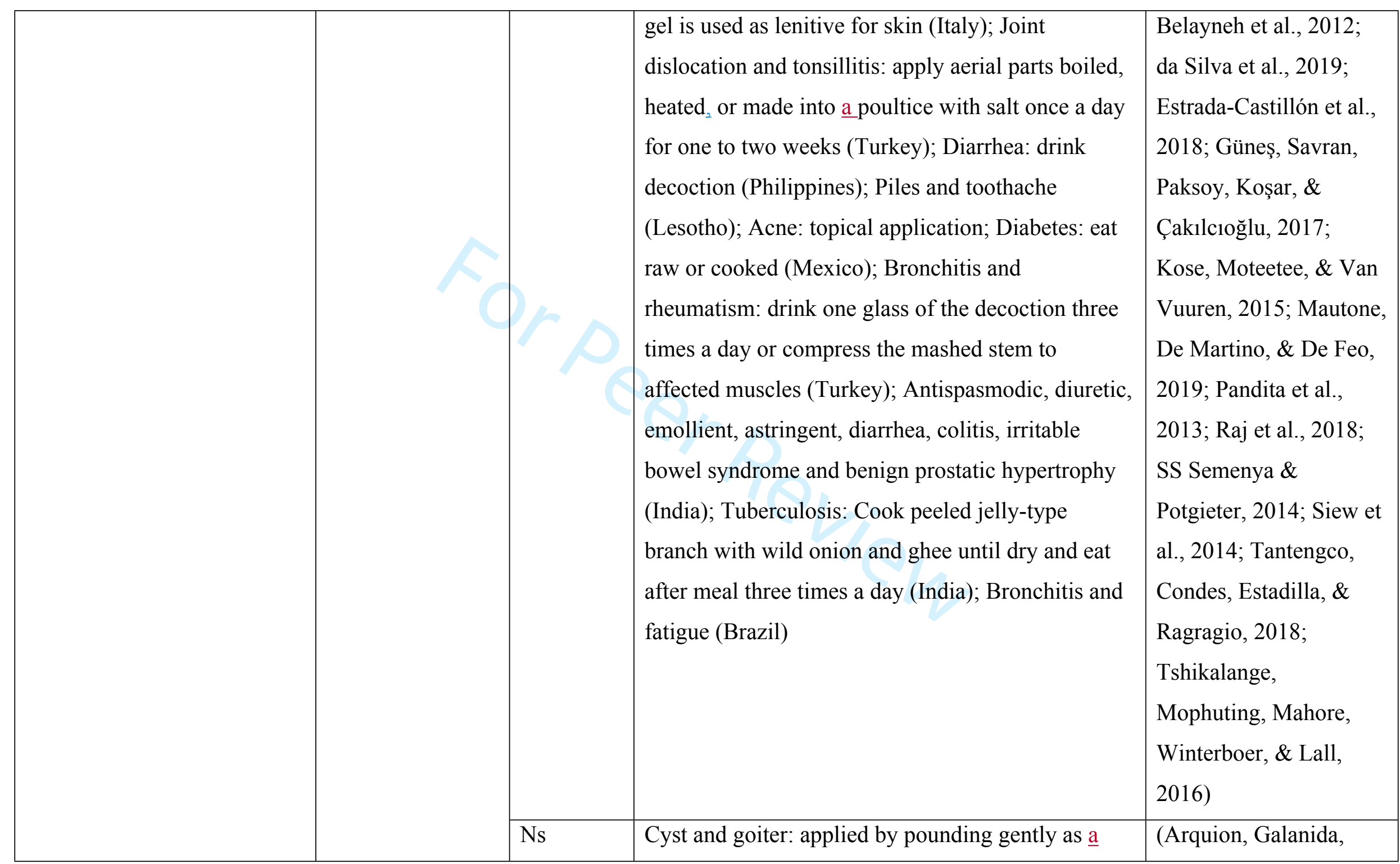




\begin{tabular}{|c|c|c|c|c|}
\hline & & & $\begin{array}{l}\text { poultice (Philippines); Dandruff (Ethiopia); Malaria } \\
\text { (Italy); Postpartum hemorrhage: combined with } \\
\text { Periploca linearifolia } \\
\text { Quart.Dill. \& A.Rich., the juice is collected, } \\
\text { filtered }_{2} \text { and used as ink to write on paper as a } \\
\text { charm hung around the neck (Ethiopia) }\end{array}$ & $\begin{array}{l}\text { Villamor, \& Aguilar, } \\
\text { 2015; Belayneh \& } \\
\text { Bussa, 2014; d'Avigdor, } \\
\text { Wohlmuth, Asfaw, \& } \\
\text { Awas, 2014; Tagarelli, } \\
\text { Tagarelli, \& Piro, 2010) }\end{array}$ \\
\hline Opuntia maxima Mill. & Prickly pear & La, Le & Bronchitis and cough: drink syrup (Portugal) & (Vinagre et al., 2019) \\
\hline \multirow{4}{*}{ Opuntia monacantha Haw } & \multirow{4}{*}{$\begin{array}{l}\text { Common prickly } \\
\text { pear }\end{array}$} & $\mathrm{La}$ & $\begin{array}{l}\text { Constipation: take } 4-6 \text { drops of latex with } 10 \text {-ten } \\
\text { drops of honey (Pakistan) }\end{array}$ & (Arshad et al., 2014) \\
\hline & & $\mathrm{Fr}$ & Used to treat gonorrhea and syphilis (Pakistan) & (Arshad et al., 2014) \\
\hline & & St & $\begin{array}{l}\text { Ash of the stem is also act as cathartic (Pakistan); } \\
\text { Dysentery: decoction (India) }\end{array}$ & (Arshad et al., 2014) \\
\hline & & $\mathrm{Wp}$ & $\begin{array}{l}\text { Digestive disorder and rheumatism: Eat the pulp } \\
\text { (India); Aids in digestion (Pakistan) }\end{array}$ & $\begin{array}{l}\text { (Sen \& Bhakat, 2018; } \\
\text { Tariq et al., 2015) }\end{array}$ \\
\hline Opuntia streptacantha Lem. & & St & $\begin{array}{l}\text { Diabetes: broiled, scrambled with eggs, or blended } \\
\text { for juice (USA) }\end{array}$ & $\begin{array}{l}\text { (Noël, Pugh, Larme, \& } \\
\text { Marsh, 1997) }\end{array}$ \\
\hline
\end{tabular}




\begin{tabular}{|c|c|c|c|c|}
\hline \multirow{3}{*}{ Opuntia stricta (Haw.) Haw. } & \multirow{3}{*}{ Erect prickly pear } & Fl. Fr & Eaten raw for hoarseness of voice (India) & (Pratap \& Prasad, 2009) \\
\hline & & Le & $\begin{array}{l}\text { Malaria: drink juice extract (Nigeria); Stroke: drink } \\
\text { one cup of decoction thrice a day; Toothache: rinse } \\
\text { the mouth with a half cup of infusion (South Africa) }\end{array}$ & $\begin{array}{l}\text { (Iyamah \& Idu, 2015; } \\
\text { Maema et al., 2016) }\end{array}$ \\
\hline & & $\mathrm{Wp}$ & Skin and wound healing: Apply the pulp (India) & (Sen \& Bhakat, 2018) \\
\hline $\begin{array}{l}\text { Opuntia triacantha (Willd.) } \\
\text { Sweet }\end{array}$ & $\begin{array}{l}\text { Jumping prickly } \\
\text { apple }\end{array}$ & Le & $\begin{array}{l}\text { Dermatitis: extract their mucilaginous material from } \\
\text { the leaf, add cooking oil, make a paste and apply } \\
\text { topically (Pakistan) }\end{array}$ & (Adnan et al., 2014) \\
\hline $\begin{array}{l}\text { Pilosocereus pachycladus } \mathrm{F} \text {. } \\
\text { Ritter }\end{array}$ & $\begin{array}{l}\text { Blue columnar } \\
\text { cactus }\end{array}$ & $\mathrm{Wp}$ & Anemia: eat cooked plant (Brazil) & (de Lucena et al., 2013) \\
\hline Pereskia aculeata Mill. & $\begin{array}{l}\text { Barbados } \\
\text { gooseberry }\end{array}$ & Ns & Anemia: infusion (Brazil) & (Bieski et al., 2012) \\
\hline Pereskia sacharosa Griseb. & $\begin{array}{l}\text { Needle Seven } \\
\text { Blade }\end{array}$ & Ns & Anemia (Brazil) & (Bieski et al., 2015) \\
\hline $\begin{array}{l}\text { Rhipsalis baccifera (J.S. } \\
\text { Muell.) Stearn }\end{array}$ & Mistletoe cactus & Le, St & $\begin{array}{l}\text { Drink infusion or decoction for diabetes (Trinidad } \\
\text { and Tobago). }\end{array}$ & (Clement et al., 2015) \\
\hline $\begin{array}{l}\text { Stenocereus stellatus (Pfeiff.) } \\
\text { Riccob. }\end{array}$ & $\begin{array}{l}\text { Baja organ pipe } \\
\text { cactus }\end{array}$ & Ap & Dysentery: boil for ten minutes and drink (Mexico) & (Hernández et al., 2003) \\
\hline
\end{tabular}


1 *Parts of the cactus used: $\mathrm{Ap}=$ Aerial part; $\mathrm{Ba}=\mathrm{Bast} ; \mathrm{Cl}=$ Cladode; $\mathrm{Ex}=$ Exudate; $\mathrm{Fl}=$ Flower; Fr $=$ Fruit; In = Indument; Jo = Joint; La = 2 Latex; Le = Leaf; $\mathrm{Ma}=$ Marrow; $\mathrm{Mu}=$ Mucilage; $\mathrm{Ns}=$ Not specified; $\mathrm{Pu}=$ Pulp; Ro = Root; $\mathrm{Sa}=\mathrm{Sap} ; \mathrm{Se}=\mathrm{Seed} ; \mathrm{St}=\mathrm{Stem} ; \mathrm{Va}=\mathrm{Vascular}$ 3 tissue; $\mathrm{Wo}=$ Wood; $\mathrm{Wp}=$ Whole plant

6 Table 2. Selected examples of bioactive compounds recently identified in cactus plants.

\begin{tabular}{|c|c|c|c|c|c|c|}
\hline Cactus species & $\begin{array}{l}\text { Plant } \\
\text { part }\end{array}$ & $\begin{array}{l}\text { Product/Group } \\
\text { of compounds }\end{array}$ & Compounds & $\begin{array}{l}\text { Extraction } \\
\text { technique }\end{array}$ & $\begin{array}{l}\text { Extraction } \\
\text { solvent }\end{array}$ & Reference \\
\hline $\begin{array}{l}\text { Opuntia ficus- } \\
\text { indica (L.) } \\
\text { Mill. }\end{array}$ & $\begin{array}{l}\text { Fruit } \\
\text { pulp }\end{array}$ & Betalains & $\begin{array}{l}\text { Histidine, glutamine, } \gamma \text {-aminobutyric acid-Bx, } \\
\text { proline-Bx, methionine-Bx, } \\
\text { betanidin- } 5-O-\beta \text {-glucoside, } \\
\text { isobetanidin- } 5-O-\beta \text {-glucoside, } \\
\text { betanidin- } 6-O-\beta \text {-glucoside, and betanidin }\end{array}$ & QuEChERS & Methanol 90\% & $\begin{array}{l}\text { (Smeriglio et } \\
\text { al., 2019) }\end{array}$ \\
\hline O. ficus-indica & $\begin{array}{l}\text { Fruit } \\
\text { pulp }\end{array}$ & Phenolics & $\begin{array}{l}\text { Protocatechuic acid-hexoside, myricetin- } \\
\text { hexoside, ferulic acid derivative, ferulic acid- } \\
\text { hexoside, guaiacyl(t8-O-4)guaiacyl-hexoside, } \\
\text { sinapic acid-hexoside, syrinigyl(t8-O- } \\
\text { 4)guaiacyl, isorhamnetin-rhamnose-rutinoside, } \\
\text { quercetin-hexoside-pentoside, isorhamnetin } \\
\text { derivative, dihydrosinapic acid hexoside, } \\
\text { secoisolariciresinol-hexoside, isorhamnetin }\end{array}$ & Sonication & $\begin{array}{l}\text { Methanol } \\
(80 \%) \\
\text { acidified with } \\
\text { formic acid } \\
(1 \%)\end{array}$ & $\begin{array}{l}\text { (Mena et al., } \\
\text { 2018) }\end{array}$ \\
\hline
\end{tabular}




\begin{tabular}{|c|c|c|c|c|c|c|}
\hline & & & $\begin{array}{l}\text { derivative, quercetin-hexoside, syringaresinol, } \\
\text { naringenin-hexoside, isorhamnetin-rutinoside, } \\
\text { naringin, guaiacyl(8-O-4)syrinigyl(8- } \\
\text { 8)guaiacyl-hexoside, feruloyl derivative, } \\
\text { trihydroxy-methoxy-flavonol }\end{array}$ & & & \\
\hline $\begin{array}{l}\text { O. ficus-indica } \\
\text { var. gialla }\end{array}$ & $\begin{array}{l}\text { Fruit } \\
\text { peels }\end{array}$ & $\begin{array}{l}\text { Betalains and } \\
\text { phenolics }\end{array}$ & $\begin{array}{l}\text { Betalains: indicaxanthin isomer I, } \\
\text { indicaxanthin isomer II, and betanidin-5-O- } \beta \text { - } \\
\text { glucoside (betanin); Phenolics: piscidic acid, } \\
\text { eucomic acid, isorhamnetin- } O \text {-(di- } \\
\text { deoxyhexosyl-hexoside), isorhamnetin- } O \text {-(di- } \\
\text { deoxyhexosyl-hexoside), } \\
\text { isorhamentinisorhamnetin- } O \text {-(deoxyhexosyl- } \\
\text { pentosyl-hexoside), } \\
\text { isorhamentinisorhamnetin- } O \text {-(deoxyhexosyl- } \\
\text { pentosyl-hexoside), } \\
\text { isorhamentinisorhamnetin- } O \text {-(pentosyl- } \\
\text { hexoside), isorhamentinisorhamnetin- } O \text { - } \\
\text { (deoxyhexosyl-hexoside), and } \\
\text { isorhamentinisorhamnetin- } O \text {-(deoxyhexosyl- } \\
\text { hexoside) }\end{array}$ & $\begin{array}{l}\text { Maceration } \\
\text { with stirring }\end{array}$ & $\begin{array}{l}\text { Ethanol: } \\
\text { water, } 80: 20 \\
\text { v/v }\end{array}$ & $\begin{array}{l}\text { (Melgar et al., } \\
2017 \text { ) }\end{array}$ \\
\hline O. ficus-indica & Fruit & Phenolics & Protocatechuic acid-hexoside, myricetin- & Sonication & Methanol & (Mena et al., \\
\hline
\end{tabular}




\begin{tabular}{|c|c|c|c|c|c|c|}
\hline & peels & & $\begin{array}{l}\text { hexoside, ferulic acid derivative, ferulic acid- } \\
\text { hexoside, guaiacyl(t8-O-4)guaiacyl-hexoside, } \\
\text { sinapic acid-hexoside, quercetin-rhamnose- } \\
\text { hexoside-rhamnose, rutin-pentoside, } \\
\text { syrinigyl(t8-O-4)guaiacyl, kaempferol-di- } \\
\text { rhamnose-hexoside, isorhamnetin- rhamnose- } \\
\text { rutinoside, quercetin-hexoside-pentoside, } \\
\text { isorhamnetin derivative,dihydrosinapic acid } \\
\text { hexoside quercetin-3-O-rutinoside (rutin), } \\
\text { secoisolariciresinol-hexoside, isorhamnetin } \\
\text { derivative, quercetin-hexoside, kaempferol- } \\
\text { rutinoside, syringaresinol, naringenin- } \\
\text { hexoside, isorhamnetin-rutinoside, } \\
\text { isorhamnetin- } C \text {-hexoside, naringin, } \\
\text { guaiacyl(8-O-4)syrinigyl(8-8)guaiacyl- } \\
\text { hexoside, and trihydroxy-methoxy-flavonol }\end{array}$ & & $\begin{array}{l}(80 \%) \\
\text { acidified with } \\
\text { formic acid } \\
(1 \%)\end{array}$ & 2018) \\
\hline $\begin{array}{l}\text { O. ficus-indica } \\
\text { var. sanguigna }\end{array}$ & $\begin{array}{l}\text { Fruit } \\
\text { peels }\end{array}$ & $\begin{array}{l}\text { Betalains and } \\
\text { phenolics }\end{array}$ & $\begin{array}{l}\text { Betalains: indicaxanthin isomer I, } \\
\text { indicaxanthin isomer II, betanidin-5-O- } \beta \text { - } \\
\text { glucoside (betanin), and isobetanin; Phenolics: } \\
\text { eucomic acid, isorhamnetin- } O \text {-(di- } \\
\text { deoxyhexosyl-hexoside), isorhamnetin- } O \text {-(di- }\end{array}$ & $\begin{array}{l}\text { Maceration } \\
\text { with stirring }\end{array}$ & $\begin{array}{l}\text { Ethanol: } \\
\text { water, } 80: 20 \\
\text { v/v }\end{array}$ & $\begin{array}{l}\text { (Melgar et al., } \\
2017 \text { ) }\end{array}$ \\
\hline
\end{tabular}




\begin{tabular}{|c|c|c|c|c|c|c|}
\hline & & & $\begin{array}{l}\text { deoxyhexosyl-hexoside), } \\
\text { isorhamentinisorhamnetin- } O \text {-(deoxyhexosyl- } \\
\text { pentosyl-hexoside), } \\
\text { isorhamentinisorhamnetin- } O \text {-(deoxyhexosyl- } \\
\text { pentosyl-hexoside), } \\
\text { isorhamentinisorhamnetin- } O \text {-(pentosyl- } \\
\text { hexoside), isorhamentinisorhamnetin- } O \text { - } \\
\text { (deoxyhexosyl-hexoside), and } \\
\text { isorhamentinisorhamnetin- } O \text {-(deoxyhexosyl- } \\
\text { hexoside) }\end{array}$ & & & \\
\hline O. ficus-indica & $\begin{array}{l}\text { Young } \\
\text { cladodes }\end{array}$ & Phenolics & $\begin{array}{l}\text { Protocatechuic acid-hexoside, myricetin- } \\
\text { hexoside, ferulic acid derivative, ferulic acid- } \\
\text { hexoside, guaiacyl(t8-O-4)guaiacyl-hexoside, } \\
\text { sinapic acid-hexoside, quercetin-rhamnose- } \\
\text { hexoside-rhamnose, rutin-pentoside, } \\
\text { syrinigyl(t8-O-4)guaiacyl, kaempferol-di- } \\
\text { rhamnose-hexoside, isorhamnetin- rhamnose- } \\
\text { rutinoside, quercetin-hexoside-pentoside, } \\
\text { isorhamnetin derivative, dihydrosinapic acid } \\
\text { hexoside quercetin-3-O-rutinoside (rutin), } \\
\text { secoisolariciresinol-hexoside, isorhamnetin }\end{array}$ & Sonication & $\begin{array}{l}\text { Methanol } \\
(80 \%) \\
\text { acidified with } \\
\text { formic acid } \\
(1 \%)\end{array}$ & $\begin{array}{l}\text { (Mena et al., } \\
\text { 2018) }\end{array}$ \\
\hline
\end{tabular}




\begin{tabular}{|c|c|c|c|c|c|c|}
\hline & & & $\begin{array}{l}\text { derivative, quercetin-hexoside, kaempferol- } \\
\text { rutinoside, syringaresinol, naringenin- } \\
\text { hexoside, isorhamnetin-rutinoside, } \\
\text { isorhamnetin-C-hexoside, naringin, } \\
\text { guaiacyl(8-O-4)syrinigyl(8-8)guaiacyl- } \\
\text { hexoside, and trihydroxy-methoxy-flavonol }\end{array}$ & & & \\
\hline
\end{tabular}




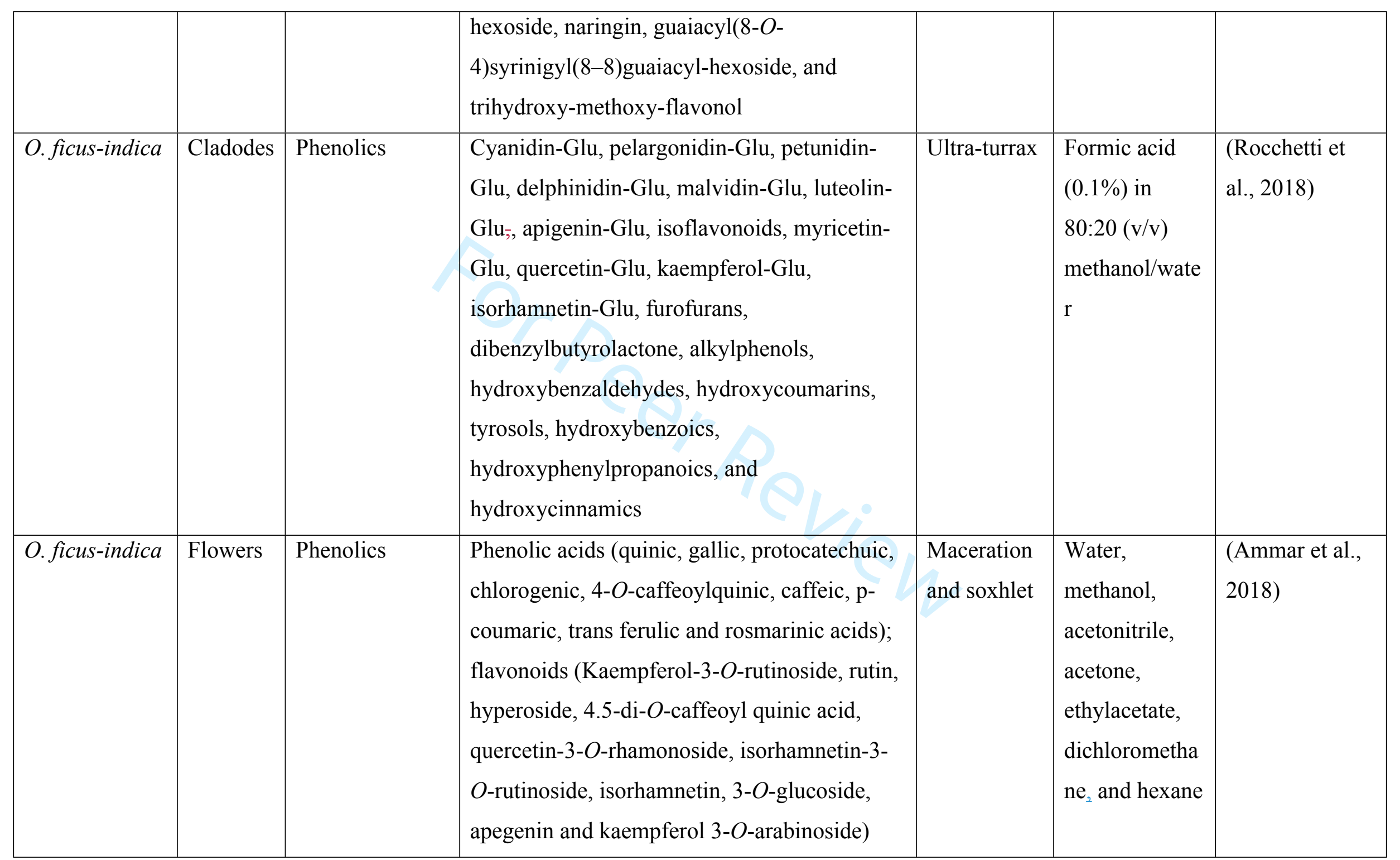




\begin{tabular}{|c|c|c|c|c|c|c|}
\hline O. ficus-indica & Seeds & Oil & $\begin{array}{l}\text { Fatty acids (linoleic, oleic acid, palmitic and } \\
\text { stearic acids), } \gamma \text {-tocopherol, and carotenoids }\end{array}$ & $\begin{array}{l}\text { Soxhlet and } \\
\text { ultrasound- } \\
\text { assisted } \\
\text { maceration } \\
\text { process }\end{array}$ & Hexane & $\begin{array}{l}\text { (Loizzo et al., } \\
\text { 2019) }\end{array}$ \\
\hline $\begin{array}{l}\text { Opuntia ficus- } \\
\text { barbarica A. } \\
\text { Berger }\end{array}$ & $\begin{array}{l}\text { Fruit } \\
\text { pulp }\end{array}$ & Phenolics & $\begin{array}{l}p \text {-Hydroxy benzoic acid, vanillin, gentisic } \\
\text { acid, protocatechuic acid, p-coumaric acid, } \\
\text { canillic acid, chrysin, gallic acid, cacid, ferulic } \\
\text { acid, homogentisic acid, luteolin, naringenin, } \\
\text { myricetin, pyrogallol, rutin, quercetin, } \\
\text { pyrocatechol, 3,4-dihydroxy benzaldehyde, } \\
\text { trans-cinnamic acid }\end{array}$ & $\begin{array}{l}\text { Combinatio } \\
\mathrm{n} \text { of } \\
\text { maceration } \\
\text { and } \\
\text { ultrasonic } \\
\text { extraction }\end{array}$ & Acetone & $\begin{array}{l}\text { (Kivrak et al., } \\
2018)\end{array}$ \\
\hline
\end{tabular}




\begin{tabular}{|c|c|c|c|c|c|c|}
\hline $\begin{array}{l}\text { Opuntia } \\
\text { engelmannii } \\
\text { Salm-Dyck ex } \\
\text { Engelm. }\end{array}$ & $\begin{array}{l}\text { Fruit } \\
\text { peels }\end{array}$ & $\begin{array}{l}\text { Betalains and } \\
\text { phenolics }\end{array}$ & $\begin{array}{l}\text { Betalains: betanidin-5- } O \text { - } \beta \text {-sophoroside, } \\
\text { Betanidin-5- } O \text { - } \beta \text {-glucoside (betanin), } \\
\text { isobetanin, gomphrenin, and betanidin; } \\
\text { Phenolics: quercetin-3- } O \text {-rutinoside, } \\
\text { kaempferol-3- } O \text {-rutinoside, } \\
\text { isorhamentinisorhamnetin- } O \text {-(deoxyhexosyl- } \\
\text { hexoside), isorhamentinisorhamnetin- } O \text { - } \\
\text { (deoxyhexosyl-hexoside), and isorhamnetin-3- } \\
O \text {-glucoside }\end{array}$ & $\begin{array}{l}\text { Maceration } \\
\text { with stirring }\end{array}$ & $\begin{array}{l}\text { Ethanol: } \\
\text { water, 80:20 } \\
\text { v/v }\end{array}$ & $\begin{array}{l}\text { (Melgar et al., } \\
\text { 2017) }\end{array}$ \\
\hline $\begin{array}{l}\text { Opuntia } \\
\text { robusta J.C. } \\
\text { Wendl. }\end{array}$ & $\begin{array}{l}\text { Fruit } \\
\text { pulp }\end{array}$ & Phenolics & $\begin{array}{l}p \text {-Hydroxy benzoic acid, vanillin, gentisic } \\
\text { acid, protocatechuic acid, p-coumaric acid, } \\
\text { canillic acid, chrysin, gallic acid, cacid, ferulic } \\
\text { acid, homogentisic acid, luteolin, naringenin, } \\
\text { myricetin, pyrogallol, rutin, quercetin, } \\
\text { pyrocatechol, 3,4-dihydroxy benzaldehyde, } \\
\text { syringic acid }\end{array}$ & $\begin{array}{l}\text { Combinatio } \\
\mathrm{n} \text { of } \\
\text { maceration } \\
\text { and } \\
\text { ultrasonic } \\
\text { extraction }\end{array}$ & Acetone & $\begin{array}{l}\text { (Kivrak et al., } \\
\text { 2018) }\end{array}$ \\
\hline $\begin{array}{l}\text { Hylocereus } \\
\text { polyrhizus } \\
\text { (F.A.C.Weber) } \\
\text { Britton \& Rose }\end{array}$ & $\begin{array}{l}\text { Fruit } \\
\text { peels }\end{array}$ & Betalains & $\begin{array}{l}\text { Betanin, isobetanin, phyllocactin, } \\
\text { butyrylbetanin, hylocerenin, isophyllocactin, } \\
\text { isobutyrylbetanin, 2'-apiosyl-phyllocactin, and } \\
\text { 2'-apiosyl-isophyllocactin }\end{array}$ & SFE & $\begin{array}{l}\mathrm{CO}_{2} \text { and } \\
\text { ethanol/water } \\
\text { as co-solvent }\end{array}$ & $\begin{array}{l}\text { (Fathordoobady } \\
\text { et al., 2019) }\end{array}$ \\
\hline Mammillaria & Fruits & Betacyanins & Betanidin 5-O- $\beta$-sophoroside, isobetanidin 5- & Grinding & Water & (Wybraniec \& \\
\hline
\end{tabular}




\begin{tabular}{|c|c|c|c|c|c|c|}
\hline spp. & & & 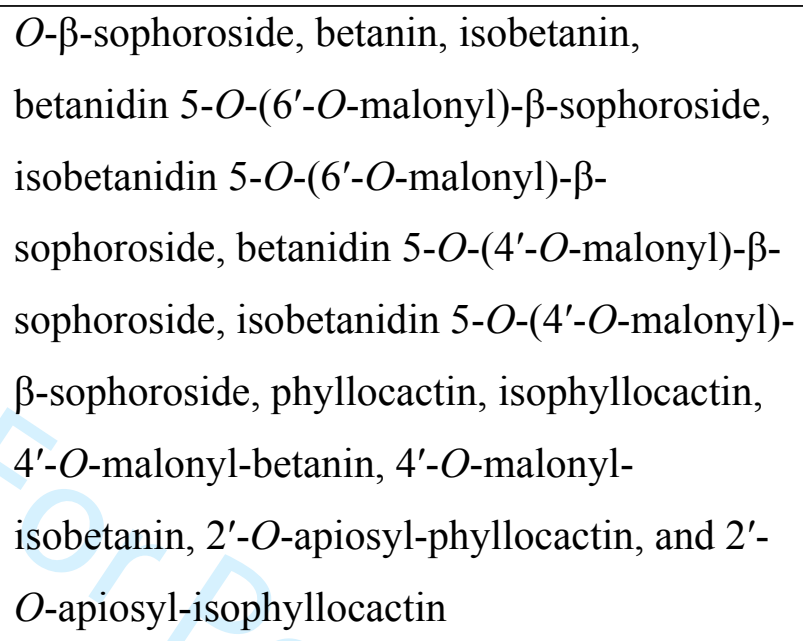 & & & $\begin{array}{l}\text { Nowak-Wydra, } \\
\text { 2007) }\end{array}$ \\
\hline $\begin{array}{l}\text { Pereskia } \\
\text { aculeata Mill. }\end{array}$ & Leaves & Phenolics & $\begin{array}{l}\text { cis } \text { Caftaric acid, trans caftaric acid, caffeic } \\
\text { acid derivative, quercetin- } O \text {-pentoside- } O \text { - } \\
\text { rutinoside, quercetin- } O \text {-pentoside- } O \text {-hexoside, } \\
\text { quercetin-3- } O \text {-rutinoside, isorhamnetin- } O \text { - } \\
\text { pentoside- } O \text {-rutinoside, isorhamnetin- } O \text { - } \\
\text { pentoside- } O \text {-hexoside, kaempferol-3- } O \text { - } \\
\text { rutinoside, and isorhamnetin-3- } O \text {-rutinoside }\end{array}$ & $\begin{array}{l}\text { Maceration } \\
\text { with } \\
\text { agitation }\end{array}$ & $70 \%$ Ethanol & $\begin{array}{l}\text { (J. A. Garcia et } \\
\text { al., 2019) }\end{array}$ \\
\hline P. aculeata & Leaves & Phenolics & Total content & Maceration & $\begin{array}{l}\text { Successively } \\
\text { with } \\
\text { petroleum } \\
\text { ether, } \\
\text { chloroform, }\end{array}$ & $\begin{array}{l}\text { (Lucèia Fàtima } \\
\text { Souza et al., } \\
2016 \text { ) }\end{array}$ \\
\hline
\end{tabular}




\begin{tabular}{|c|c|c|c|c|c|c|}
\hline & & & & & and methanol & \\
\hline P. aculeata & Leaves & Essential oils & $\begin{array}{l}\text { (E)- } \beta \text {-Lonone, dihydro- } \beta \text {-agarofuran, cis- } \\
\text { dihydro-mayurone, caryophyllene oxide, } \alpha \text { - } \\
\text { Muurolol, ar-tumerone, 14-hydroxy-(Z)- } \\
\text { caryophyllene,(Z)-3-hexenyl salicylate, 14- } \\
\text { hydroxy-9-epi-(E)-caryophyllene, 2-hexyl- } \\
\text { (E)-cinnamaldehyde, 1-octadecene, 2- } \\
\text { ethylhexyl, acorone, cyclopentadecanolide, 1- } \\
\text { nonadecen-ol, (Z,ZZ)-methyl-4,6- } \\
\text { hexadecadiene, (5E,9E)-farnesyl acetone, } \\
\text { methyl hexadecanoate, isopropyl } \\
\text { hexadecanoate, methyl linoleate, methyl } \\
\text { octadecanoate, linoleic acid, and phytol }\end{array}$ & $\begin{array}{l}\text { Hydrodistill } \\
\text { ation }\end{array}$ & Water & \\
\hline $\begin{array}{l}\text { Polaskia } \\
\text { chichipe } \\
\text { Backbg. }\end{array}$ & Plant & $\begin{array}{l}\text { Triterpenoid } \\
\text { saponins }\end{array}$ & $\begin{array}{l}\text { Chichipenoside A methyl ester, } \\
\text { chichipenoside A, chichipenoside B, } \\
\text { chichipenoside B methyl ester, chichipenoside } \\
\text { C, oleanolic acid } 3 \text { - } O \text { - } \beta \text {-D- } \\
\text { glucopyranosyl }(1 \rightarrow 2)-[\alpha-\mathrm{L}- \\
\text { rhamnopyranosyl }(1 \rightarrow 3)]-\beta \text {-D-glucopyranosyl }\end{array}$ & $\begin{array}{l}\text { Maceration } \\
\text { / isolation } \\
\text { silica gel } \\
\text { column } \\
\text { chromatogr } \\
\text { aphy }\end{array}$ & $\begin{array}{l}\text { Chloroform } \\
\text { followed by } \\
\text { methanol }\end{array}$ & $\begin{array}{l}\text { (Fujihara et al., } \\
\text { 2017) }\end{array}$ \\
\hline
\end{tabular}




\begin{tabular}{|c|c|c|c|c|c|c|}
\hline & & & $\begin{array}{l}\text { 28-O- } \beta \text {-D glucuronopyranoside, and } \beta \text { - } \\
\text { sitosterol 3- } O \text {-glucoside }\end{array}$ & & & \\
\hline $\begin{array}{l}\text { Stenocereus } \\
\text { pruinosus } \\
\text { (Otto ex } \\
\text { Pfeiff.) Buxb. }\end{array}$ & $\begin{array}{l}\text { Red } \\
\text { fruits }\end{array}$ & $\begin{array}{l}\text { Betalains and } \\
\text { phenolics }\end{array}$ & $\begin{array}{l}\text { Betalains: Gomphrenin I, isogomphrenin I, 2- } \\
\text { descarboxy-betanin, phyllocactin, 4'-O- } \\
\text { malonyl-betanin or betanidin-5-O-(6'-O-3- } \\
\text { hydroxy-butyryl)- } \beta \text {-glucoside, } \\
\text { isophyllocactin, 6'-O-malonyl-2- } \\
\text { descarboxybetanin, betanidin derivative, 6'-O- } \\
\text { malonyl-2-descarboxyisobetanin, } \\
\text { isoindicaxanthin, and indicaxanthin; } \\
\text { Phenolics: caffeoyl hexoside I, caffeoyl } \\
\text { hexoside II, p-coumaroyl quinic acid, } \\
\text { quercetin 3-O-rutinoside, and isorhamnetin } \\
\text { hexoside }\end{array}$ & $\begin{array}{l}\text { Ultrasonic } \\
\text { bath }\end{array}$ & $\begin{array}{l}\text { Methanol:trifl } \\
\text { uoroacetic } \\
\text { acid } 1 \% \text { in } \\
\text { water }(80: 20 \text {, } \\
\mathrm{v} / \mathrm{v})\end{array}$ & $\begin{array}{l}\text { (García-Cruz et } \\
\text { al., 2017) }\end{array}$ \\
\hline $\begin{array}{l}\text { Stenocereus } \\
\text { stellatus } \\
\text { (Pfeiff.) } \\
\text { Riccob. }\end{array}$ & $\begin{array}{l}\text { Red } \\
\text { fruits }\end{array}$ & $\begin{array}{l}\text { Betalains and } \\
\text { phenolics }\end{array}$ & $\begin{array}{l}\text { Betalains: Gomphrenin I, isogomphrenin I, 2- } \\
\text { descarboxy-betanin, phyllocactin, 4'-O- } \\
\text { malonyl-betanin or betanidin-5-O-(6'-O-3- } \\
\text { hydroxy-butyryl)- } \beta \text {-glucoside, } \\
\text { isophyllocactin, 6'-O-malonyl-2- } \\
\text { descarboxybetanin, betanidin derivative, 6'-O- } \\
\text { malonyl-2-descarboxyisobetanin, }\end{array}$ & $\begin{array}{l}\text { Ultrasonic } \\
\text { bath }\end{array}$ & $\begin{array}{l}\text { Methanol:trifl } \\
\text { uoroacetic } \\
\text { acid } 1 \% \text { in } \\
\text { water }(80: 20 \text {, } \\
\mathrm{v} / \mathrm{v})\end{array}$ & $\begin{array}{l}\text { (García-Cruz et } \\
\text { al., 2017) }\end{array}$ \\
\hline
\end{tabular}




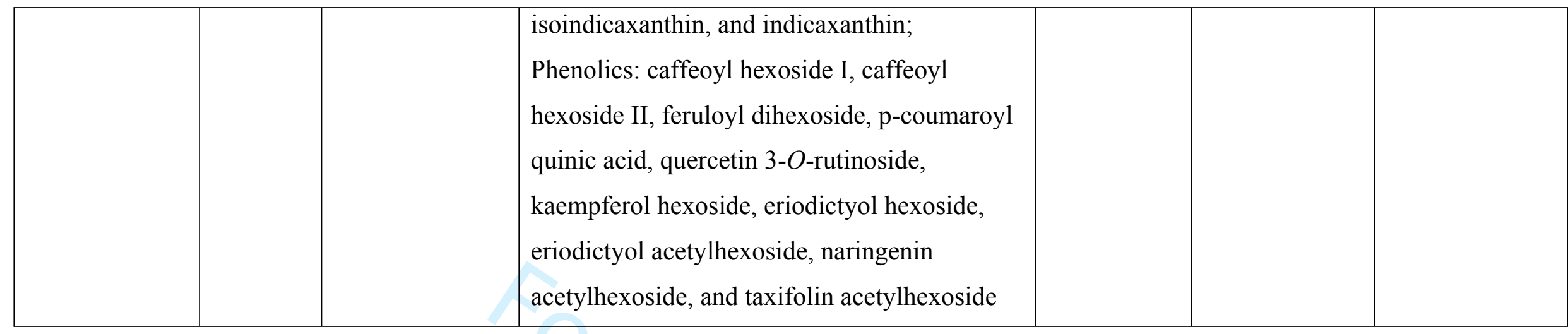

1

2

3 Table 3: Pharmacological potentials of Cactus

\begin{tabular}{|l|l|l|l|}
\hline \multicolumn{1}{|c|}{ Cactus species } & \multicolumn{1}{|c|}{ Mart/Extract } & \multicolumn{1}{c|}{ References } \\
\hline Antimicrobial & Fruit extract & $\begin{array}{l}\text { Disc diffusion assay against } \\
\text { B. subtilis, M. lysodeikticus, } \\
\text { E. faecalis, K. pneumoniae, } \\
\text { E. coli, P. fluorescens Candida albicans, Trichoderma } \\
\text { harzianum, Penicillium cyclopium, Aspergillus niger, } \\
\text { Doratomyces stemonitis, Phialophora fastigiata, Fusarium } \\
\text { oxysporum }\end{array}$ & (Katanić et al., 2019) \\
&
\end{tabular}




\begin{tabular}{|c|c|c|c|}
\hline Opuntia albicarpa & Seed oil & $\begin{array}{l}\text { Disc diffusion assay against Escherichia coli, } \\
\text { Staphylococcus aureus, Listeria monocytogenes, } \\
\text { Pseudomonas aeruginosa, Saccharomyces cerevisiae, and } \\
\text { Candida albicans }\end{array}$ & (Ramírez-Moreno et al., 2017) \\
\hline $\begin{array}{l}\text { Opuntia ficus- } \\
\text { indica }\end{array}$ & Seed oil & $\begin{array}{l}\text { Disc diffusion assay against Escherichia coli, } \\
\text { Staphylococcus aureus, Listeria monocytogenes, } \\
\text { Pseudomonas aeruginosa Saccharomyces cerevisiae, and } \\
\text { Candida albicans }\end{array}$ & \\
\hline $\begin{array}{l}\text { Opuntia ficus- } \\
\text { indica }\end{array}$ & Cladode extract & $\begin{array}{l}\text { Antibacterial activity against Escherichia coli, Salmonella } \\
\text { enterica ser. Typhimurium, } \\
\text { Enterobacter aerogenes, Enterococcus faecalis, } \\
\text { Staphylococcus aureus } \\
\text { Antibiofilm activity against Staphylococcus aureus }\end{array}$ & (Blando et al., 2019) \\
\hline $\begin{array}{l}\text { Opuntia } \\
\text { oligacantha }\end{array}$ & Bioextract & Disc diffusion assay against Salmonella typhimurium & (Cenobio-Galindo et al., 2019) \\
\hline Pereskia aculeata & $\begin{array}{l}\text { Ethanolic leaf; } \\
\text { chloroform and } \\
\text { methanholic leaf } \\
\text { extract }\end{array}$ & $\begin{array}{l}\text { MIC study against Escherichia coli, Klebsiella pneumoniae, } \\
\text { Morganella morganii, Proteus mirabilis,Pseudomonas } \\
\text { aeruginosa, Enterococcus faecalis, Listeria } \\
\text { monocytogenes, Methicillin-resistant Staphylococcus aureus }\end{array}$ & $\begin{array}{l}\text { (J. A. Garcia et al., 2019; } \\
\text { Lucèia Fàtima Souza et al., } \\
\text { 2016) }\end{array}$ \\
\hline $\begin{array}{l}\text { Pereskia } \\
\text { grandifolia }\end{array}$ & Methanolic leaf & $\begin{array}{l}\text { Pseudomonas aeruginosa, Staphylococcus aureus, and } \\
\text { Bacillus subtilis }\end{array}$ & (Philip et al., 2009) \\
\hline
\end{tabular}




\begin{tabular}{|c|c|c|c|}
\hline Pereskia bleo & $\begin{array}{l}\text { Methanolic and ethyl } \\
\text { acetate leaves extracts; } \\
\text { its dichloromethane }\end{array}$ & $\begin{array}{l}\text { P. aeruginosa, } \\
\text { methicillin-resistant S.aureus }\end{array}$ & (Wahab et al., 2009) \\
\hline \multicolumn{4}{|l|}{ Antiviral } \\
\hline $\begin{array}{l}\text { Opuntia } \\
\text { streptacantha }\end{array}$ & Cladode extract & $\begin{array}{l}\text { Intracellular virus replication inhibition and extracellular } \\
\text { virus inactivation }\end{array}$ & (Ahmad et al., 1996) \\
\hline Opuntia spp. & Stem extract & Inhibits intracellular replication & (Gentile et al., 2004) \\
\hline Opuntia dillenii & $\begin{array}{l}\text { Methanolic fruit } \\
\text { extract }\end{array}$ & $\begin{array}{l}\text { Antiviral activity against herpes simplex, vaccinia,_vesicular } \\
\text { stomatitis virus, coxsackie-virus, respiratory syncytieal } \\
\text { virus, feline corona-virus, feline herpes virus, para-influenza } \\
\text { virus, reo virus-1, sindbis virus, and puntatorovirus }\end{array}$ & (Jang et al., 2014) \\
\hline \multicolumn{4}{|l|}{ Antioxidant } \\
\hline $\begin{array}{l}\text { Opuntia } \\
\text { ficus-indica }\end{array}$ & Hydroalcoholic extract & $\begin{array}{l}\text { Scavenging DPPH radical } \\
\text { Reducing power of } \mathrm{Fe}^{2+} \\
\text { (FRAP assay) }\end{array}$ & (Benattia \& Arrar, 2018) \\
\hline $\begin{array}{l}\text { Opuntia } \\
\text { ficus-indica }\end{array}$ & Fruit extract & $\begin{array}{l}\text { MDA and GSH study in rat erythrocytes, Increase in the } \\
\text { level of superoxide dismutase (SOD), reduced glutathione } \\
(\mathrm{GSH})\end{array}$ & $\begin{array}{l}\text { (Abd El-Razek \& Hassan, } \\
\text { 2011; Alimi et al., 2012; Alimi } \\
\text { et al., 2013) }\end{array}$ \\
\hline $\begin{array}{l}\text { Opuntia } \\
\text { fieusindicaficus } \\
\underline{\text { Indica }}\end{array}$ & $\begin{array}{l}\text { By-products obtained } \\
\text { from cladodes and } \\
\text { fruits (fibers) }\end{array}$ & ABTS and FRAP assay & (Bensadón et al., 2010) \\
\hline
\end{tabular}




\begin{tabular}{|c|c|c|c|}
\hline $\begin{array}{l}\text { Opuntia ficus indica } \\
\text { (L.) Mill. }\end{array}$ & Whole fruit juice & $\begin{array}{l}\text { DPPH scavenging assay, Trolox-equivalent antioxidant } \\
\text { capacity (TEAC) })_{2} \text { and oxygen radical absorbance capacity } \\
\text { (ORAC) assays }\end{array}$ & $\begin{array}{l}\text { (Albano et al., 2015; Enza } \\
\text { Maria Galati et al., 2003) }\end{array}$ \\
\hline $\begin{array}{l}\text { Opuntia ficus indica } \\
\text { f. inermis }\end{array}$ & $\begin{array}{l}\text { Methanolic root } \\
\text { extract }\end{array}$ & DPPH, reducing power & (Alimi et al., 2010) \\
\hline $\begin{array}{l}\text { Opuntia ficus- } \\
\text { indica (L.) Mill. }\end{array}$ & $\begin{array}{l}\text { Polysachharides } \\
\text { Polysaccharides from } \\
\text { cladode extracts }\end{array}$ & DPPH, reducing power, metal chelating assay & (Ben Saad et al., 2017) \\
\hline $\begin{array}{l}\text { Opuntia ficus- } \\
\text { indica }\end{array}$ & Cladode extract & $\begin{array}{l}\text { Oxygen Radical Absorbance Capacity (ORAC) Trolox } \\
\text { equivalent antioxidant capacity (TEAC) and cellular } \\
\text { antioxidant activity in red blood cells (CAA-RBC) }\end{array}$ & (Blando et al., 2019) \\
\hline Opuntia dillenii & Fruit extract & DPPH, ABTS scavenging assay, & (Katanić et al., 2019) \\
\hline $\begin{array}{l}\text { Opuntia ficus- } \\
\text { indica (variety: } \\
\text { Sanguigna and } \\
\text { Surfarina) }\end{array}$ & Seed oil extract & ABTS, DPPH, FRAP, and $\beta$-carotene bleaching tests & $\begin{array}{l}\text { (Loizzo et al., 2019; Ramírez- } \\
\text { Moreno et al., 2017) }\end{array}$ \\
\hline Opuntia albicarpa & Seed oil extract & DPPH scavenging assay & (Ramírez-Moreno et al., 2017) \\
\hline $\begin{array}{l}\text { Opuntia } \\
\text { oligacantha }\end{array}$ & Bioextract & DPPH, ABTS scavenging assay & (Cenobio-Galindo et al., 2019) \\
\hline Opuntia elatior & Hydroalcoholic extract & DPPH scavenging assay & (Chintu et al., 2017) \\
\hline
\end{tabular}




\begin{tabular}{|c|c|c|c|}
\hline & of the fruit & & \\
\hline Opuntia dillenii & $\begin{array}{l}\text { Methanolic fruit } \\
\text { extract }\end{array}$ & $\begin{array}{l}\text { DPPH, hydrogen peroxide and hydroxyl radicals scavenging } \\
\text { assay }\end{array}$ & (Jang et al., 2014) \\
\hline Opuntia stricta & $\begin{array}{l}\text { Ethanol extract of } \\
\text { cladode }\end{array}$ & $\begin{array}{l}\text { DPPH, Nitric oxide, Hydrogen peroxide, } \\
\text { Phosphomolybdenum scavenging assay }\end{array}$ & (Izuegbuna et al., 2019) \\
\hline Pereskia aculeata & $\begin{array}{l}\text { Aqueous ethanolic } \\
\text { leaf extract; } \\
\text { Leaf extract; } \\
\text { methanolic leaf } \\
\text { extract; } \\
\text { Fruit extract }\end{array}$ & $\begin{array}{l}\text { DPPH, ABTS, OH radicals scavenging assay; DPPH } \\
\text { bioautography; ORAC assay }\end{array}$ & $\begin{array}{l}\text { (da Silva et al., 2019; Pinto et } \\
\text { al., 2012; Ruiz del Castillo, } \\
\text { Santa-María, Herraiz, \& } \\
\text { Blanch, 2003; Lucèia Fàtima } \\
\text { Souza et al., 2016) }\end{array}$ \\
\hline Pereskia bleo & $\begin{array}{l}\text { Ethyl acetate, hexane, } \\
\text { methanol, ethanol leaf } \\
\text { extract }\end{array}$ & DPPH scavenging & $\begin{array}{l}\text { (Hassanbaglou et al., 2012; } \\
\text { Sim et al., 2010; Wahab et al., } \\
2009 \text { ) }\end{array}$ \\
\hline \multicolumn{4}{|l|}{ Antidiabetic } \\
\hline $\begin{array}{l}\text { Opuntia ficus- } \\
\text { indica (variety: } \\
\text { Sanguigna and } \\
\text { Surfarina) }\end{array}$ & Seed oil extract & $\alpha$-amylase and $\alpha$-glucosidase enzyme inhibitory assay & (Loizzo et al., 2019) \\
\hline $\begin{array}{l}\text { Opuntia ficus- } \\
\text { indica }\end{array}$ & $\begin{array}{l}\text { Oil extract } \\
\text { Boiled cactus stem }\end{array}$ & $\begin{array}{l}\text { Decrease post-prandial hyperglycaemia. Decrease serum } \\
\text { glucose level, decrease serum insulin, and plasma glucose- }\end{array}$ & $\begin{array}{l}\text { (Abd El-Razek \& Hassan, } \\
\text { 2011; Berraaouan et al., 2015; }\end{array}$ \\
\hline
\end{tabular}




\begin{tabular}{|c|c|c|c|}
\hline & $\begin{array}{l}\text { Aqueous extract fruit } \\
\text { skin and pulp extract } \\
\text { aqueous extract dry } \\
\text { powder }\end{array}$ & $\begin{array}{l}\text { dependent insulinotropic peaks, } \\
\text { Increase in plasma insulin }\end{array}$ & $\begin{array}{l}\text { Berraaouan et al., 2014; } \\
\text { Godard et al., 2010; Hwang et } \\
\text { al., 2017; López-Romero et al., } \\
\text { 2014; Roman-Ramos et al., } \\
\text { 1995; Van Proeyen et al., } \\
\text { 2012) }\end{array}$ \\
\hline $\begin{array}{l}\text { Opuntia } \\
\text { oligacantha }\end{array}$ & $\begin{array}{l}\text { Methanolic fruit } \\
\text { extract }\end{array}$ & $\alpha$-Amylase and $\alpha$-glucosidase enzyme inhibitory assay & (Medina-Pérez et al., 2019) \\
\hline Opuntia elatior & $\begin{array}{l}\text { Hydro-alcoholic } \\
\text { extract of the fruit }\end{array}$ & $\alpha$-Amylase inhibitory assay & (Chintu et al., 2017) \\
\hline $\begin{array}{l}\text { Opuntia } \\
\text { streptacantha }\end{array}$ & Fruit juice & $\begin{array}{l}\alpha \text {-Glucosidase enzyme inhibitory assay; } \\
\text { blocking the hepatic glucose output in streptozotocin } \\
\text { streptozotocin-induced diabetic rats }\end{array}$ & $\begin{array}{l}\text { (Andrade-Cetto \& Wiedenfeld, } \\
\text { 2011; Becerra-Jiménez \& } \\
\text { Andrade-Cetto, 2012) }\end{array}$ \\
\hline Pereskia bleo & $\begin{array}{l}\text { Aqueous leaf, stem } \\
\text { and root extracts }\end{array}$ & $\begin{array}{l}\text { decreased fasting plasma glucose level in alloxanised } \\
\text { alloxanized diabetic rat }\end{array}$ & $\begin{array}{l}\text { (Mat Darus \& Mohamad, } \\
\text { 2017) }\end{array}$ \\
\hline \multicolumn{4}{|c|}{ Anti-inflammatory } \\
\hline Opuntia dillenii & $\begin{array}{l}\text { Alcoholic flower, } \\
\text { fruits }_{2} \text { and stem } \\
\text { Aqueous fruit extracts }\end{array}$ & $\begin{array}{l}\text { Anti-inflammatory } \\
\text { Analgesic in carrageenan-induced rat paw eedema test }\end{array}$ & $\begin{array}{l}\text { (Ahmed et al., 2005; Loro et } \\
\text { al., 1999) }\end{array}$ \\
\hline $\begin{array}{l}\text { Opuntia ficus- } \\
\text { indica }\end{array}$ & $\begin{array}{l}\text { Methanol extract of } \\
\text { stem }\end{array}$ & $\begin{array}{l}\text { Anti-inflammatory activity in adjuvant-induced chronic } \\
\text { inflammation model in mice }\end{array}$ & (Park et al., 2001) \\
\hline
\end{tabular}




\begin{tabular}{|c|c|c|c|}
\hline Opuntia stricta & $\begin{array}{l}\text { Ethanol extract of } \\
\text { cladode }\end{array}$ & RAW 264.7 cells based anti-inflammatory assay & (Izuegbuna et al., 2019) \\
\hline Pereskia bleo & $\begin{array}{l}\text { Dichloromethane } \\
\text { extract of leaves }\end{array}$ & Carrageenan-induced paw edema in rats & (Qureshi et al., 2019) \\
\hline Pereskia aculeate & $\begin{array}{l}\text { Methanolic leaf } \\
\text { extract }\end{array}$ & Acute and chronic dermatitis mice model & (Pinto Nde et al., 2015) \\
\hline \multicolumn{4}{|l|}{ Antiulcer } \\
\hline $\begin{array}{l}\text { Opuntia ficus indica } \\
\text { f. inermis }\end{array}$ & $\begin{array}{l}\text { Methanolic root } \\
\text { extract } \\
\text { Cladode powder } \\
\text { Purified mucilage }\end{array}$ & $\begin{array}{l}\text { In vivo ulcerative mice model, } \\
\text { Ethanol-Ethanol-induced rat model; } \downarrow \text { MDA level, peroxidase } \\
\text { activities }_{2} \text { and protein carbonyls generation, } \uparrow \text { CAT level }\end{array}$ & $\begin{array}{l}\text { (Akacha et al., 2018; Alimi et } \\
\text { al., 2010; E. M. Galati et al., } \\
\text { 2001; Maataoui et al., 2018) }\end{array}$ \\
\hline \multicolumn{4}{|l|}{ Hepatoprotective } \\
\hline $\begin{array}{l}\text { Opuntia ficus- } \\
\text { indica (L.) Mill. }\end{array}$ & $\begin{array}{l}\text { Polysaccharides from } \\
\text { cladode extracts } \\
\text { Fruit juice }\end{array}$ & $\begin{array}{l}\text { Decreased LPO, MDA, increase in hepatic CAT, } \mathrm{SOD}_{2} \text { and } \\
\text { GPx activities; } \\
\text { Protects the liver from organophosphoreus pesticides } \\
\text { Protect and restore the damages of liver tissue. } \\
\text { Normalization of aspartate aminotransferase (AST), alanine } \\
\text { aminotransferase (ALT), alkaline phosphatase (ALP) level } \\
\text { in the rat model; } \\
\downarrow \text { AST, ALT level }\end{array}$ & $\begin{array}{l}\text { (Abd El-Razek \& Hassan, } \\
\text { 2011; Ben Saad et al., 2017; } \\
\text { Ncibi et al., 2008) }\end{array}$ \\
\hline Opuntia robusta & Fruit juice extracts & Attenuated Acetaminophen-induced injury markers AST, & (González-Ponce et al., 2016) \\
\hline
\end{tabular}




\begin{tabular}{|c|c|c|c|}
\hline & & $\mathrm{ALT}_{2}$ and $\mathrm{ALP}_{2}$ and improved liver histology & \\
\hline $\begin{array}{l}\text { Opuntia } \\
\text { streptacantha }\end{array}$ & Fruit juice extracts & $\begin{array}{l}\text { Attenuated Acetaminophen-induced injury markers AST, } \\
\mathrm{ALT}_{2} \text { and } \mathrm{ALP}_{2} \text { and improved liver histology }\end{array}$ & \\
\hline \multicolumn{4}{|l|}{ Cytotoxic } \\
\hline Opuntia dillenii & $\begin{array}{l}\text { Fruit extract } \\
\text { methanolic fruit } \\
\text { extract }\end{array}$ & $\begin{array}{l}\text { MTT assay on Human breast cancer cells (MCF-7), human } \\
\text { colon cancer cells (LoVo), and human hepatocytes (HepG2) } \\
\text { HeLa, CRFK } 2 \text { and Vero cell lines }\end{array}$ & $\begin{array}{l}\text { (Jang et al., 2014; Katanić et } \\
\text { al., 2019) }\end{array}$ \\
\hline Opuntia stricta & $\begin{array}{l}\text { Ethanol extract of } \\
\text { cladode }\end{array}$ & MTT assay on U937 and Jurkat cell lines & (Izuegbuna et al., 2019) \\
\hline $\begin{array}{l}\text { Opuntia } \\
\text { polyacantha }\end{array}$ & $\begin{array}{l}\text { Alkaloids from dried } \\
\text { plants }\end{array}$ & MTT assay on MCF-7 and WRL-68 cell lines & (Abdulazeem et al., 2018) \\
\hline $\begin{array}{l}\text { Lophophora } \\
\text { williamsii }\end{array}$ & Methanol extract & $\begin{array}{l}\text { Cytotoxic effects against MCF7, L5178Y-R, U937, and } \\
\text { L929 cell lines by MTT assay }\end{array}$ & (Franco-Molina et al., 2003) \\
\hline $\begin{array}{l}\text { Pachycereus } \\
\text { marginatus }\end{array}$ & $\begin{array}{l}\text { Aqueous methanolic } \\
\text { stem extract }\end{array}$ & $\begin{array}{l}\text { Cytotoxic effects against L5178Y-R tumphomalymphoma } \\
\text { murine cells }\end{array}$ & (Gomez-Flores et al., 2019) \\
\hline Pereskia bleo & $\begin{array}{l}\text { Ethyl acetate, hexane, } \\
\text { methanol, ethanol leaf } \\
\text { extract }\end{array}$ & $\begin{array}{l}\text { Cytotoxic activity towards MCF-7, HT-29, and CEM- } \\
\text { SS cell lines }\end{array}$ & (Wahab et al., 2009) \\
\hline \multicolumn{4}{|l|}{ Antigenotoxic } \\
\hline $\begin{array}{l}\text { Opuntia dillenii } \\
\text { (Ker Gawl.) }\end{array}$ & Fruit extract & DNA protection assay & (Katanić et al., 2019) \\
\hline
\end{tabular}




\begin{tabular}{|c|c|c|c|}
\hline $\begin{array}{l}\text { Opuntia ficus- } \\
\text { indica }\end{array}$ & $\begin{array}{l}\text { Fruit extract } \\
\text { Cladode extract }\end{array}$ & DNA protection assay & $\begin{array}{l}\text { (Madrigal-Santillán et al., } \\
\text { 2013; Zorgui et al., 2009) }\end{array}$ \\
\hline \multicolumn{4}{|l|}{ Cardioprotective } \\
\hline $\begin{array}{l}\text { Opuntia ficus- } \\
\text { indica }\end{array}$ & $\begin{array}{l}\text { Cladode extract } \\
\text { dried leaves }\end{array}$ & $\begin{array}{l}\text { Inhibited LDL oxidation and formation of foam cells; } \\
\text { inhibition of NADPH oxidase (NOX2); reduced } \\
\text { development of atherosclerotic lesions; } \\
\uparrow \text { in HDL cholesterol level concomitantly with } \downarrow \text { in LDL } \\
\text { cholesterol }\end{array}$ & $\begin{array}{l}\text { (Garoby-Salom et al., 2016; } \\
\text { Keller et al., 2015; Linarès et } \\
\text { al., 2007) }\end{array}$ \\
\hline $\begin{array}{l}\text { Opuntia } \\
\text { streptacantha }\end{array}$ & Cladode extract & $\begin{array}{l}\text { Inhibited LDL oxidation and formation of foam cells; } \\
\text { inhibition of NADPH oxidase (NOX2); reduced } \\
\text { development of atherosclerotic lesions }\end{array}$ & $\begin{array}{l}\text { (Garoby-Salom et al., 2016; } \\
\text { Keller et al., 2015) }\end{array}$ \\
\hline Opuntia robusta & Fruit extract & $\begin{array}{l}\text { Lowered the plasma levels of LDL cholesterol; } \\
\text { improves the platelet function and haemostatic balance }\end{array}$ & $\begin{array}{l}\text { (Budinsky et al., 2001; } \\
\text { Wolfram et al., 2002) }\end{array}$ \\
\hline \multicolumn{4}{|l|}{ Neuroprotective } \\
\hline Opuntia dillenii & Polysaccharide & Ischemia-reperfusion injury in rats & \multirow[t]{2}{*}{ (X. Huang et al., 2009) } \\
\hline $\begin{array}{l}\text { Opuntia milpa } \\
\text { altaalta }\end{array}$ & Polysaccharide & $\begin{array}{l}\text { Normalization of neuroprotective biochemical markers like } \\
\text { lactate dehydrogenase (LDH), superoxide dismutase (SOD), } \\
\text { glutathione (GSH), and total antioxidant competence (T- } \\
\text { AOC) level }\end{array}$ & \\
\hline $\begin{array}{l}\text { Opuntia ficus- } \\
\text { indica }\end{array}$ & $\begin{array}{l}\text { Ethyl acetate fractions } \\
\text { of the fruits and stems }\end{array}$ & $\begin{array}{l}\text { Inhibited lipid peroxidation and scavenged 1,1-diphenyl-2- } \\
\text { picrylhydrazyl free radicals. }\end{array}$ & $\begin{array}{l}\text { (Dok-Go et al., 2003; J. H. } \\
\text { Kim et al., 2006; Kwon et al., }\end{array}$ \\
\hline
\end{tabular}




\begin{tabular}{|c|c|c|c|}
\hline & & $\begin{array}{l}\text { enhanced cognitive performance in the mouse by } \\
\text { ameliorating scopolamine-induced cognitive dysfunction; } \\
\text { Neuroprotective action against N-methyl-D-aspartate } \\
\text { NMDA, kainate } \mathrm{KA}_{2} \text { and OGD oxygen deprivation oxygen }\end{array}$ & 2018) \\
\hline
\end{tabular}

2 Table 4: Some examples of clinical trials using cacti species

\begin{tabular}{|c|c|c|c|c|c|}
\hline Plant & Type & dose & Time & Main conclusion & Reference \\
\hline $\begin{array}{l}\text { Pereskia } \\
\text { aculeata }\end{array}$ & Flour & $400 \mathrm{~g}$ & $\begin{array}{l}6 \\
\text { months }\end{array}$ & $\begin{array}{l}\text { Consumption improves } \\
\text { intestinal health. }\end{array}$ & (Vieira et al., 2019) \\
\hline $\begin{array}{l}\text { Nopalea } \\
\text { cochenillifera }\end{array}$ & $\begin{array}{l}\text { fresh } \\
\text { beverage }\end{array}$ & $\begin{array}{l}50 \mathrm{~g} / 250 \\
\mathrm{~mL}\end{array}$ & 30 days & $\begin{array}{l}\text { Good alternative for } \\
\text { diabetes-II }\end{array}$ & $\begin{array}{l}\text { (Fabela-Illescas, Avila-Dominguez, Hernandez-Pacheco, Ariza, } \\
\text { \& Betanzos-Cabrera, 2015) }\end{array}$ \\
\hline \multirow{3}{*}{$\begin{array}{l}\text { Opuntia ficus- } \\
\text { indica }\end{array}$} & $\begin{array}{l}\text { steamed } \\
\text { nopal }\end{array}$ & $\begin{array}{l}50 \text { and } \\
300 \mathrm{~g}\end{array}$ & $150 \mathrm{~min}$ & $\begin{array}{l}\text { Good properties for } \\
\text { patients with diabetes-II. }\end{array}$ & (López-Romero et al., 2014) \\
\hline & \begin{tabular}{|l}
\multicolumn{2}{l}{ Litramine } \\
IQP G- \\
002AS \\
tablets (a \\
natural fiber \\
complex)
\end{tabular} & $300 \mathrm{mg}$ & $\begin{array}{l}12 \\
\text { weeks }\end{array}$ & $\begin{array}{l}\text { Effective in promoting } \\
\text { weight loss. }\end{array}$ & (Grube, Chong, Lau, \& Orzechowski, 2013) \\
\hline & $\begin{array}{l}\text { cladode and } \\
\text { fruit-skin }\end{array}$ & $1 \mathrm{~g}$ & 1 hour & $\begin{array}{l}\text { Good properties during } \\
\text { rest and after endurance }\end{array}$ & (Van Proeyen et al., 2012) \\
\hline
\end{tabular}




\begin{tabular}{|c|c|c|c|c|}
\hline $\begin{array}{l}\text { extract } \\
\text { capsules }\end{array}$ & & & exercise in healthy men. & \\
\hline $\begin{array}{l}\text { OpunDia }^{\mathrm{TM}} \\
\text { Capsules }\end{array}$ & $400 \mathrm{mg}$ & $\begin{array}{l}16 \\
\text { weeks }\end{array}$ & $\begin{array}{l}\text { Lowering effects and the } \\
\text { long-term safety for of } \\
\text { blood glucose } \\
\text { management. }\end{array}$ & (Godard et al., 2010) \\
\hline $\begin{array}{l}\mathrm{NeOpuntia}^{\mathrm{T}} \\
\mathrm{M} \text { capsules }\end{array}$ & $\begin{array}{l}1.6 \mathrm{~g} \text { per } \\
\text { meal }\end{array}$ & 6 weeks & $\begin{array}{l}\text { Improvement of } \\
\text { parameters associated } \\
\text { with cardiovascular risks. }\end{array}$ & (Linarès et al., 2007) \\
\hline $\begin{array}{l}\text { Fresh fruit } \\
\text { pulp }\end{array}$ & $250 \mathrm{~g}$ & 6 weeks & $\begin{array}{l}\text { Positive effects on the } \\
\text { body's redox balance in } \\
\text { healthy humans }\end{array}$ & (Tesoriere, Butera, Pintaudi, Allegra, \& Livrea, 2004) \\
\hline
\end{tabular}


1 Figure captions

2 Figure 1: Aspect of some of the widely found Cactus species in the world. Some pictures are reproduced under the terms of the Creative 3 Commons CC BY license from Shackleton et al. (Shackleton, Witt, Piroris, \& van Wilgen, 2017); Grace (Grace, 2019).

4 Figure 2: Representation of 12 types of growth forms of the Cactaceae family. Reproduced under the terms of the Creative Commons CC BY 5 license from Novoa et al. (Novoa et al., 2015). 

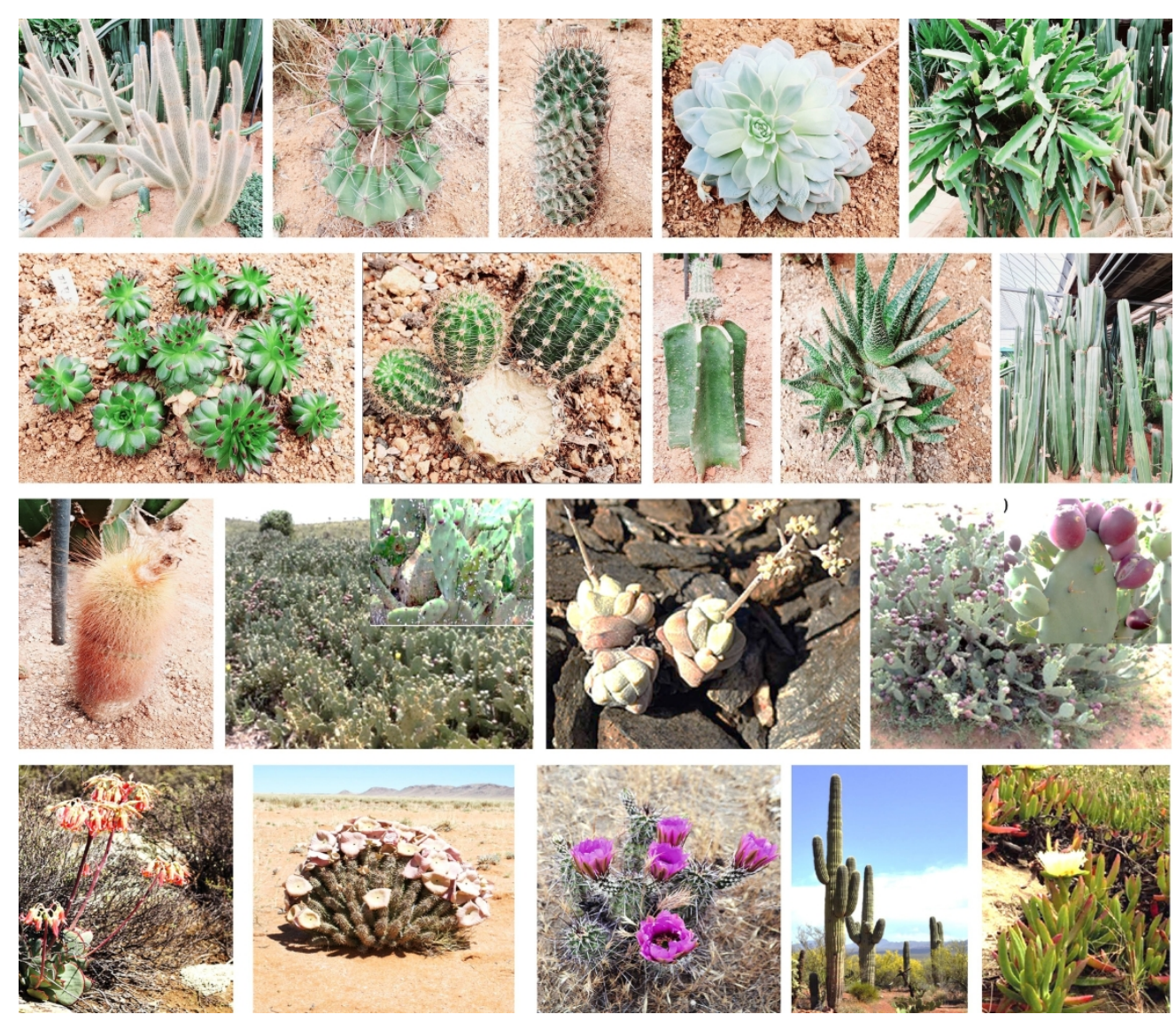

$299 \times 258 \mathrm{~mm}(300 \times 300 \mathrm{DPI})$ 


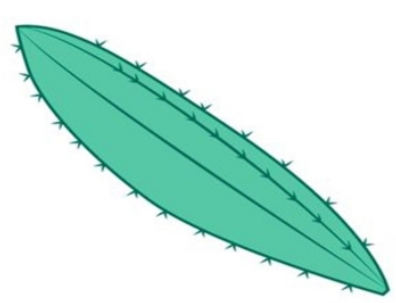

Angled

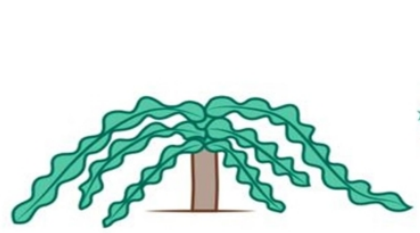

Leaf-like

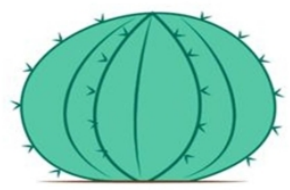

Globose

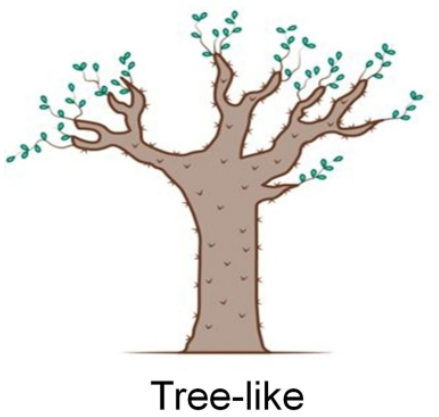

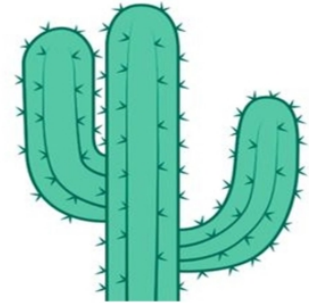

Cylindrical

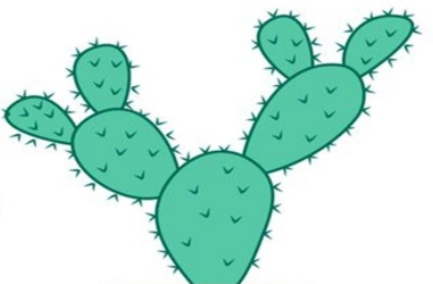

Flattened-padded
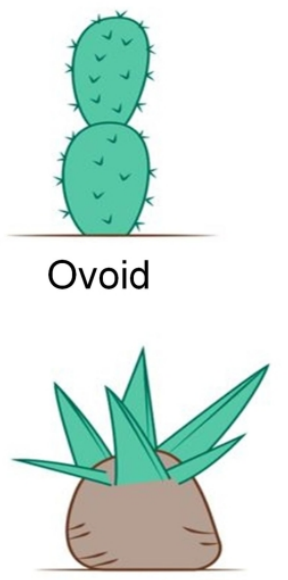

Tuberculate

Cushion like

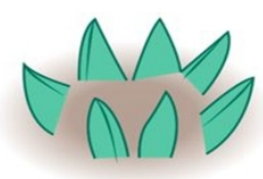

Geophytic
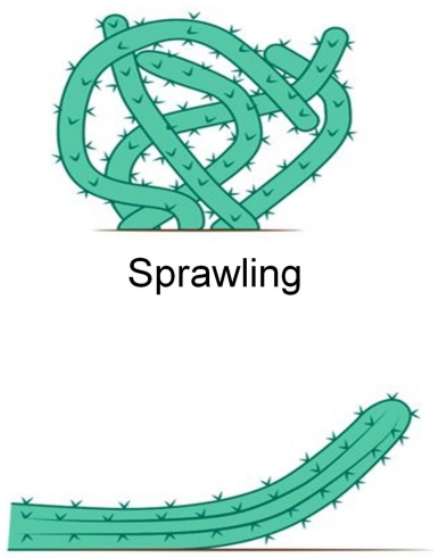

Prostrate 